\title{
NARRATIVA E INTERATIVIDADE em meios audiovisuais
}

Dissertação apresentada ao Programa de Pós-Graduação em Ciências da Comunicação, da Escola de Comunicações e Artes da Universidade de São Paulo como exigência parcial para obtenção de Título de Mestre.

Área de concentração: Estudos dos Meios da Produção Midiática

Orientador: Prof. Dr. Roberto Franco Moreira 


\section{FOLHA DE APROVAÇÃO}

Alexandre Machado de Sá

Narrativa e Interatividade em meios audiovisuais

Dissertação apresentada à Escola de Comunicações e Artes da Universidade de São Paulo para obtenção do titulo de mestre.

Área de Concentração: Estudos dos Meios da Produção Midiática

Aprovado em:

Banca Examinadora:

Prof. Dr.

Instituição:

Assinatura:

Prof. Dr.

Instituição:

Assinatura:

Prof. Dr.

Instituição: Assinatura: 


\section{RESUMO}

Em “O Discurso da Narrativa" Gerrard Genette faz uma análise de $\grave{A}$ La Recherche du Temps Perdu de Proust, destrinchando a poética narrativa e fornecendo elementos eficazes para a compreensão e estudo de qualquer outra obra narrativa. Genette sugere a análise através de 3 chaves: Tempo (que pode ser subdividido em Ordem, Duração e Freqüência), Modos de Narrativa e Voz.

A narrativa é cada vez mais presente nos videogames e para compreender as congruências e diferenças entre a narrativa literária e a narrativa que permite interação, própria dos jogos eletrônicos, o jogo de aventura "Full Throttle", de Tim Schafer, foi observado sob a ótica de "O Discurso da Narrativa".

A partir dos elementos fornecidos pelo estudo, esse trabalho propõe a criação de uma obra: LIMBO, um jogo eletrônico com a aplicação objetiva dos recursos narrativos observados. O documento de produção do jogo, é apresentado de forma completa, procurando abordar o maior número de características que deverão ser implementadas através dos seguintes tópicos: visão geral, sinopse, descrição dos personagens, descrição do universo onde se passa a história, argumento, descrição do funcionamento do jogo, mecânica do jogo, descrição progressiva fase a fase, descrição do espaço e descrição da direção de arte.

Palavras-chave: Narrativa. Interatividade. Jogos eletrônicos. Videogame. 


\begin{abstract}
In "Narrative Discourse" Gérrard Genette makes an analyze of $\grave{A}$ La Recherche $d u$ Temps Perdu by Proust, breaking apart the poetic narrative and bringing new effective elements to comprehend and study any other kind of narrative. Genette suggests that this analyze should be taken by three basic keys: Time (could be divided in Order, Duration and Frequency), Mode and Voice.
\end{abstract}

The narrative have been more and more common in the videogames and to comprehend the congruencies and differences between the literature narrative and a narrative that allows interaction, of the electronic games, the adventure "Full Throttle" from 1994, by Tim Schafer, was observed by the eye of "Narrative Discourse".

Using the elements found in this study, this work consists on the creation of a new product: LIMBO, an electronic game with the objective application of this narrative features observed. The "Game Document" is presented in a completed way, trying to approach the biggest number of characteristics that will be implemented by the topics: overview, synopsis, characters description, description of the universe where the story happens, argument, game play, level design and concept arts.

Keyword: Narrative. Interactivity. Electronic games. Videogames. 


\section{SUMÁRIO}

1 INTRODUÇÃO

2 GÉRARD GENETTE ENCONTRA FULL THROTTLE 10

$\begin{array}{ll}2.1 \text { ORDEM } & 15\end{array}$

2.2 DURAÇÃO 21

2.3 FREQÜÊNCIA

$\begin{array}{ll}2.4 \mathrm{MODO} & 34\end{array}$

$2.5 \mathrm{VOZ} \quad 45$

2.6 REFLEXÕES DO ENCONTRO 58

3 LIMBO - DOCUMENTO DE PRODUÇÃO DO JOGO

3.1 VISÃO GERAL

3.2 SINOPSE $\quad 59$

3.3 DESCRIÇÃO DOS PERSONAGENS $\quad 60$

3.4 DESCRIÇÃO DO MUNDO 64

3.5 DESCRIÇÃO GERAL DO FUNCIONAMENTO DO JOGO 65

3.6 MECÂNICA DO JOGO $\quad 68$

3.6.1 OBJETIVOS E REGRAS $\quad 68$

3.6.2 SISTEMA DE PONTUAÇÃO 70

3.6.3 DESCRIÇÃO DA INTERFACE $\quad 70$

3.6.4 DESCRIÇÃO DE COMANDOS

3.6.4.1 CONTROLE DE MOVIMENTAÇÃO 72

$\begin{array}{ll}\text { 3.6.4.2 CONTROLE VISUAL } & 72\end{array}$

3.6.4.3 CONTROLE DE HABILIDADES AVANÇADAS 73 
3.8 DESCRIÇÃO PROGRESSIVA FASE A FASE

3.9 DESCRIÇÃO DO ESPAÇO NAVEGÁVEL (“LEVEL” DESIGN)

3.10 DIREÇÃO DE ARTE

4 CONCLUSÃO

98

LISTA DE OBRAS UTILIZADAS

102

ANEXO - FLUXOGRAMA DE EVENTOS DE LIMBO

103 


\section{INTRODUÇÃO}

Em todos os trabalhos artísticos que produzi - curtas-metragens, histórias em quadrinhos, multimídia ou jogos - há sempre uma característica que os une: minha vontade de contar histórias. Meu interesse pela narrativa é o fio que alinhava todas as formas de expressão que tenho trabalhado. A questão que mais me intriga é: como, e até que ponto, a narrativa deve ser usada nas mídias interativas - em especial, nos jogos? Será que a interação diminuiria as possibilidades narrativas? Insatisfeito com as soluções que tenho encontrado para o uso da narrativa nos meus trabalhos interativos, pretendo explorar as fronteiras entre interatividade e narrativa.

A partir desse questionamento decidi dividir essa pesquisa em duas partes. A primeira delas propõe analisar e discutir um jogo eletrônico a partir da ótica de um teórico da narrativa literária. Com esse trabalho pretendo elucidar os principais pontos de convergência entre os vídeo games e a narrativa.

Ao abordar as questões narrativas, Salen; Zimmerman, (2004. p. 379) constatam que

A intersecção dos termos "narrativa" e "jogo" vem sendo surpreendentemente abordada no estudo e no design de jogos. Nos últimos anos, estudiosos e acadêmicos da literatura, cinema, e narrativa eletrônica, como o hipertexto, têm se voltado diretamente para o estudo dos jogos para computador. Diciplinas alheias ao design de jogos tem estudado jogos sob perspectivas de seus próprios campos, o debate chegou a quem tem o direito de fazer definições sobre os jogos e a narrativa. Essa disputa turva é sintomática da dificuldade inerente do estudo de uma mídia externa no contexto próprio de uma outra disciplina. 
Por isso, meu objetivo com esse estudo não é apenas a análise dos jogos sob a perspectiva narrativa e sim explorar, através dessa pesquisa, como as questões narrativas podem ser utilizadas na criação de jogos.

Não pretendo provar que jogos são (ou não são) narrativos ou definir os limites entre a narrativa e os jogos eletrônicos. Meu foco é descobrir como os jogos podem usar os fundamentos que estruturam as narrativas de formas mais interessantes, utilizando esses elementos de um modo criativo, levando os à suas últimas conseqüências.

Para o desenvolvimento dessa pesquisa, optei por analisar o jogo "Full Throttle", de Tim Schaffer, sob a perspectiva de Gérard Genette, autor do livro "O Discurso da Narrativa”, em que ele se utiliza do livro $\grave{A}$ La Recherche $d u$ Temps Perdu, de Marcel Proust e elabora uma metodologia eficaz para o estudo de qualquer obra narrativa. Através dessa confrontação de meios, pretendo destrinchar alguns elementos da poética narrativa.

Após esse levantamento proveniente do estudo realizado na primeira parte desse trabalho, um projeto de um jogo eletrônico (Documento de produção do jogo. $)^{1}$ será desenvolvido levando em conta os elementos narrativos que julgar pertinentes.

Acredito que ao utilizar tais elementos narrativos descobertos, no documento de produção do jogo proposto, passarei a trabalhar com novos paradigmas, munido de um repertório inédito no meu trabalho pessoal de designer de jogos. Se até hoje desenvolvi jogos que foram escritos intuitivamente sem uma compreensão maior da poética narrativa, tenho certeza que a partir dessa pesquisa poderei propor algo diferente, buscando uma nova forma que alie a narrativa 
ao jogo de um modo mais simbiótico, explorando possibilidades estéticas que tenho deixado escapar.

Para que qualquer percepção de presunção a respeito do que pretendo realizar seja desfeita, quero esclarecer que os limites que pretendo ultrapassar são pessoais e estão ligados ao meu trabalho artístico como desenvolvedor de jogos eletrônicos. Porém acredito que ao propor esse jogo com tão forte ligação à narrativa, vou contribuir com outros designers de jogos ao oferecer uma forma específica de documentar projetos de jogos, já que não há um padrão formal de como um documento de produção do jogo deve ser apresentado.

A temática e a história desse projeto vão ser definidas a partir dos elementos levantados durante a pesquisa do primeiro capítulo. O jogo a ser criado será uma metáfora a respeito do ato de contar histórias e de como a participação do jogador interfere na percepção e no desenvolvimento da trama. Por isso, apesar da diferença formal e de uma certa desconexão entre os dois capítulos dessa dissertação, é através da ligação dessas duas partes que o trabalho é construído. Deixando que as relações entre os pontos levantados no primeiro capitulo possam ser reconhecidas no segundo capítulo: o documento de produção do jogo.

\footnotetext{
${ }^{1}$ Game Doc é o nome dado ao projeto de um jogo a ser produzido com todas as informações pertinentes a execução da obra estão descritas e esquematizadas. Para evitar o uso de expressões estrangeiras, sugiro aqui a tradução: Documento de produção do jogo.
} 


\section{CAPÍTULO 1}

\section{GÉRARD GENETTE ENCONTRA FULL THROTTLE}

Em “O Discurso da Narrativa”, de Genette. À La Recherche du Temps Perdu de Proust é tratado como um "pretexto, reservatório de exemplos e lugar de ilustração para uma poética narrativa, onde seus traços específicos se perderiam na transcendência das 'leis do gênero"” (GENETTE, 1985, p.20). Procurando o específico encontra-se o universal, sugere o autor, e é esse método universal, não restrito exclusivamente à Recherche ou mesmo às obras literárias, que usarei como base de meu estudo.

O ponto de partida de Genette na análise do discurso narrativo é a divisão de Tzevetan Todorov, de 1966, em que são propostas três categorias: tempo, que aborda as relações entre tempo da história e o tempo de discurso; o aspecto, maneira pela qual a história é percebida pelo narrador; e o modo, tipo de discurso utilizado pelo narrador. Todorov ilustrava a primeira categoria através das deformações temporais: infidelidades à ordem cronológica dos acontecimentos. O aspecto recolheria as questões do ponto de vista sob o qual é feita a narração, e o modo, os problemas de distância entre o narrador e sua narração. Genette propôs uma reorganização dessas três classes fundamentais de determinação da seguinte forma: tempo, ligada às relações temporais entre o discurso e à diegése; modos de narrativa, ligada às modalidades de representação, é uma reunião do aspecto e do modo na divisão criada por Todorov; por fim, Genette cria uma nova determinação que enfoca as questões ligadas à narração, definindo a situação ou instância narrativa: a voz. Tempo e modo funcionam ambos no nível das relações entre história e narrativa, enquanto voz designa ao mesmo tempo as relações entre narração e narrativa, e entre narração e história"(GENETTE, 1985, p. 30). 
Essas três classes propostas determinam a posição dos capítulos do livro "O Discurso da Narrativa", dividido em ordem, duração, freqüência, modo e voz.

Munido das ferramentas fornecidas por Genette em "O Discurso da Narrativa", pretendo fazer uma análise do jogo "Full Throttle" e descobrir como a teoria narrativa foi aplicada (e como pode ser aplicada) nesta nova forma de contar histórias: o videogame. Minha primeira idéia, ao pesquisar esta nova linguagem, foi utilizar a teoria da narrativa cinematográfica, já que a proximidade entre jogos e cinema é notória; porém julguei ser mais prudente ir direto à teoria literária - acredito que encontrarei conceitos mais adequados, que me ajudarão a compreender mais claramente a metodologia ao narrar uma história, mesmo que haja a interferência do destinatário da narração: o narratário ${ }^{2}$.

Por que "Full Throttle"

No início da década de 90 um gênero de jogos se tornou extremamente popular - os jogos de aventura com gráficos - que, ao contrário dos outros gêneros, privilegiava a história em relação à ação. Por essa característica tais jogos ficaram conhecidos como "interactive storytelling" (narrações interativas). Dentre as produtoras que se especializavam nesse gênero específico, a Lucas Arts se destacou. Não por acaso a Lucas Arts é ligada a uma empresa cinematográfica - a Lucas Films, ambas de George Lucas. O gênero desenvolveu-se rapidamente, numa seqüência de títulos que exemplificam sua evolução. O uso da linguagem cinematográfica como recurso narrativo era maior a cada novo lançamento. A utilização de dispositivos como o corte, a montagem contínua, a trilha sonora e principalmente o roteiro ficaram cada vez mais evidentes. Junto com a evolução dos jogos de aventura com gráficos, um autor se destacava - Tim Schafer. Em quase todas as equipes dos jogos lançados pela

\footnotetext{
${ }^{2}$ Termo usado por Genette ao tratar do destinatário da narração.
} 
Lucas Arts, Schaffer era integrante. Em 93 estreou como autor no jogo "Day of the Tentacle", que ajudou a consolidar o novo gênero, tornando-se um dos mais aclamados "game designers" mundiais. Esse autor de jogos foi um dos primeiros criadores de jogos a ganhar status de artista - como um diretor de cinema; sua assinatura em um trabalho atestava a qualidade da obra e seu nome ajudava a vender os jogos. Em 1995, a Lucas Arts lança "Full Throttle", que rapidamente se torna uma referência dos jogos de aventura com gráficos, mostrando a possibilidade de um jogo contar uma história complexa, sem que a jogabilidade fosse comprometida.

$\mathrm{O}$ argumento do jogo

"Full Throttle" se passa num futuro próximo e conta a história de Ben, líder dos polecats, uma gangue de motoqueiros à procura de trabalho. Malcon Corley, proprietário da maior fabricante de motocicletas dos Estados Unidos, a Corley Motors, e o vice-presidente da companhia, Ripburger, oferecem um trabalho à gangue - escoltá-los à próxima reunião dos acionistas da empresa. Ben não aceita a proposta e os capangas de Ripburger o deixam desmaiado em uma caixa de lixo. A gangue acredita que seu líder acabou aceitando o trabalho e junta-se aos empresários como escolta. Ao acordar, Ben descobre que é uma armadilha e tenta interceptar a comitiva antes que cheguem ao destino. Enquanto tenta alcançá-los, Ben descobre que os parafusos que prendem a roda dianteira ao garfo de sua moto foram soltos e sofre um acidente. Miranda, uma jornalista fotográfica, o encontra desacordado e o leva a Maureen, uma mecânica local. Ben acorda na casa de Maureen, que tenta consertar a moto dele. O motoqueiro a ajuda a encontrar peças e, com a motocicleta recuperada, volta à estrada. Mas já é tarde demais: Ripburger assassina Malcon Corley e os polecats são incriminados. Miranda consegue fotografar os golpes que mataram o velho Corley, mas é descoberta antes 
de fugir, deixando a câmera nas mãos dos capangas de Ripburger. Ao encontrar Malcon, Ben ainda consegue ouvir suas últimas palavras, e fica sabendo que o empresário tem uma filha bastarda: Maureen. Ripburger pede aos capangas que eliminem a herdeira e as fotos. Maureen está consertando uma torradeira quando vê o reflexo do assassino; ela aperta um botão que abre um alçapão sob os pés do bandido, derrubando e o deixando inconsiente. Maureen pega o filme da câmera que estava com o assassino e foge; quando Ben volta à oficina, já não há ninguém. Ben decide procurá-la no lugar onde a garota aparece numa fotografia num porta-retrato. Porém, como é acusado de ter sido o assassino de Malcon Corley, ao chegar no esconderijo de Maureen, ela foge mais uma vez. Pensando em atrair Maureen para uma cilada, Ripburger cria uma competição de destruição de carros que premiará o vencedor com a primeira motocicleta de Malcon Corley, veículo que havia sido consertado por Maureen e seu pai. Maureen é membro de outra gangue, os vultures, e esconde-se na caverna do bando. Ben a encontra mais uma vez, mas dessa vez é preso pelos vultures. Maureen o está torturando, quando descobre que ele não é o responsável pela morte de seu pai. Ao revelarem as fotos tudo se esclarece e os dois elaboram um plano para desmascarar Ripburger. Ambos se inscrevem na competição de destruição de carros e conseguem enganar Ripburger, fazendo-o acreditar que foram mortos por seus capangas. Com a motocicleta recuperada, Maureen descobre a chave de um cofre de seu pai escondida no motor. Esse cofre guarda uma fita com o testamento de Malcon Corley. Durante a cerimônia de posse de Ripburger, na Corley Motors, Ben interrompe a projeção da apresentação dos novos planos do novo presidente e exibe no telão a seqüência de fotos que mostram o assassinato de Malcon Corley. Em seguida reproduz a fita com o testamento narrado pelo próprio Malcon. Desmascarado na frente da multidão, Ripburger se desespera e foge, roubando um caminhão da companhia. Ben e Maureen voltam para a estrada, quando um enorme caminhão se aproxima e tenta atropelá-los. Numa emocionante seqüência final, Ben 
enfrenta Ripburger, conseguindo salvar Maureen e deixando o vilão cair num enorme precipício.

Histórias como a de Ben não são comuns nos jogos eletrônicos, mesmo quase dez anos após o lançamento de "Full Throttle". Poucos são os jogos com roteiros tão elaborados, personagens interessantes e tramas tão bem engendradas. Essa poderia bem ser a sinopse de um filme, uma história em quadrinhos, ou até mesmo de um conto; a diferença é que nessa história o narratário é convidado a uma participação ativa e a continuidade da história depende de suas ações.

A história de "Full Throttle" é contada dividindo-se em trechos interativos e não-interativos. O jogo começa com um longo trecho não-interativo - uma locução “em off”: "Quando sinto o cheiro de asfalto eu penso em Maureen. Essa foi a última sensação que tive antes de apagar, e a primeira imagem que vi quando acordei foi seu rosto. Ela disse que consertaria minha moto...". Enquanto ouvimos esse texto introdutório a câmera faz uma pan mostrando um vale no deserto, por onde passa uma estreita estrada de asfalto. A partir daí os personagens e a trama vão sendo apresentados até que finalmente alcançamos o primeiro trecho interativo, em que somos solicitados a participar da história e controlar as ações de Ben, tentando resolver os problemas propostos. Conforme atingimos os objetivos de cada trecho interativo do jogo, voltamos a uma nova seqüência não-interativa, que apresenta mais desafios que deverão ser solucionados no trecho interativo seguinte. A história é contada dessa maneira, intercalando trechos com e sem interatividade. 


\subsection{ORDEM}

No primeiro capítulo de "O Discurso da Narrativa”, Genette aborda a questão temporal relacionada às distorções temporais da narrativa. Numa narrativa há dois tempos: o tempo da história contada e o tempo que se leva para contar essa história - "uma das funções da narrativa é transformar o tempo em um outro tempo" (METZ, 1968, p. 27). Essa oposição entre essas duas temporalidades é um traço característico em qualquer tipo de narrativa cinematográfica, oral, literária... ${ }^{3}$. Porém a narrativa literária escrita tem um espaço mais difícil de se precisar do que as narrativas orais e fílmicas, já que seu consumo se faz no tempo variável da leitura. Essa relação de dualidade temporal nas histórias contadas por jogos acaba se assemelhando ao que acontece na narrativa literária. Se o tempo de leitura depende da velocidade de cada leitor, o mesmo podemos dizer dos jogos, que terão os tempos da narrativa variáveis dependendo de quão rápido os jogadores solucionam os desafios. Por outro lado, nos trechos onde não é exigido interação do jogador, a história é contada como num filme, em cenas de transição. Poderíamos dizer que os jogos acabam misturando uma temporalidade variável - própria da literatura - com a temporalidade fixa - oral e cinematográfica. As questões da "ordem" tratam das relações entre ordem temporal de sucessão dos acontecimentos na história contada e a ordem pseudo-temporal da disposição narrativa. $\mathrm{O}$ estudo da ordem temporal confronta a ordem em que os acontecimentos são dispostos no discurso narrativo com a ordem da história. A discordância entre esses dois aspectos é chamado de anacronia - um dos recursos tradicionais da narração literária. O início de uma história, por exemplo, já com uma ação em pleno desenvolvimento, seguido de um voltar atrás explicativo é um pilar tradicional do gênero épico (prática conhecida como in Media

\footnotetext{
${ }^{3}$ Genette julgava essa questão menos pertinente nas histórias em quadrinhos; porém, se considerarmos que o tempo na narrativa gráfica é marcado pelo espaço e não pelo tempo, veremos que mesmo aqui essa oposição se faz presente.
} 
res). Genette propõe o uso de novos termos para a análise dessas relações temporais:

- prolepse - toda a manobra narrativa consistindo em evocar ou contar de antemão um acontecimento ulterior;

- analepse - Toda ulterior evocação de um acontecimento anterior ao ponto que se está da história;

- anacronia - esse termo geral é reservado a quaisquer outras formas de discordância que não sejam prolepses ou analepses.

A elipse, que é um avanço sem recuo, não é uma anacronia e sim uma simples aceleração da narrativa; apesar de afetar o tempo, a ordem cronológica é preservada.

Toda anacronia constitui, em relação à narrativa na qual se insere, uma narrativa temporalmente segunda, subordinada à primeira. Podendo ir ao passado ou ao futuro, mais ou menos longe do momento "presente" (momento da história interrompido para dar lugar), o alcance da anacronia se refere a essa distância temporal E a amplitude refere-se a duração de história na anacronia.

Analepses

Genette classifica vários tipos de analepses, que podem ser:

externas - a amplitude total permanece exterior à narrativa primeira; por isso, esse tipo de analepse jamais interfere na narrativa primeira; sua função se restringe a um esclarecimento sobre algum antecedente. Genette denomina essas analepses de heterodiegéticas, pois reportam-se a linhas de histórias e a um conteúdo diegético diferente da narrativa primeira; 
internas - o alcance não é anterior ao início da narrativa, referindo-se a mesma linha de ação da narrativa primeira; portanto, analepses homodiegéticas. A interferência na narrativa primeira, neste caso, é praticamente inevitável, assim como a redundância, já que é um regresso a algo que já foi dito. A função mais freqüente deste recurso é a modificação posterior de eventos passados. Essa dupla interpretação propicia-nos uma espécie de narrativa dupla, dando novo ponto de vista e significado a um acontecimento já abordado pela narrativa;

mistas - o ponto de alcance é anterior ao início da narrativa primeira, mas a amplitude é posterior;

completivas (ou reenvios) - compreendem segmentos retrospectivos que preenchem uma lacuna deixada pela narrativa primeira;

parciais - retrospecção que termina numa elipse, sem alcançar a narrativa primeira; completas - a amplitude alcança a narrativa primeira, cobrindo toda a sua duração; esse recurso está ligado à prática de iniciar uma história já com a ação em desenvolvimento. Uma analepse mista vai ao encontro da narrativa primeira não no início, mas no próprio ponto onde havia sido interrompida para dar-lhe lugar. A amplitude é igual ao alcance, por isso podemos chamá-las de analepses internas completas. A narrativa analéptica interrompe-se numa elipse e a narrativa primeira é retomada onde havia sido abandonada.

\section{Prolepses}

Bem menos usuais do que as analepses são as prolepses. A antecipação é muito pouco freqüente na tradição narrativa ocidental. A preocupação com o suspense narrativo - própria da concepção clássica do romance - não se ajusta a tal prática. Do mesmo modo, as prolepses se dividem em externas e internas. Certas prolepses externas põem em jogo a própria 
instância narrativa, por isso essas antecipações no presente não afetam apenas a temporalidade da narrativa, mas também questões relacionadas à voz.

As prolepses internas têm as mesmas características das analepses desse tipo.

As prolepses completivas compensam futuras elipses, enquanto as prolepses repetitivas dobram um segmento narrativo a vir - um anúncio -, assim como as analepses repetitivas, um retorno. A função das prolepses repetitivas está ligada à expectativa que criam no espírito do leitor. É importante não confundir esses anúncios explícitos com sugestões, que não são mais do que esboços para preparar os leitores. Há também o recurso de lograr falsos esboços para induzir o leitor a uma projeção falsa.

Genette não encontra exemplos de prolepses completas, que se prolongassem até o momento do desenlace ou até o momento narrativo, apontando que prolepses são sempre parciais, porque mesmo com todas as anacronias, a direção temporal é sempre respeitada. Enquanto numa analepse o tempo corre ao encontro da narrativa primeira, numa prolepse o tempo se distancia do ponto onde a narrativa deu lugar a esse novo segmento, ficando impossível um reencontro.

\section{Anacronias}

Em À la Recherche du Temps Perdu Genette encontra anacronias duplas, que criam verdadeiros ziguezagues: analepses sobre prolepses e prolepses sobre analepses. Analepses abertas, cuja terminação não é identificável, provam a existência de segmentos narrativos temporalmente indefinidos. Nos capítulos seguintes Genette expõe outros critérios para 
agrupamentos sem que a ordem cronológica dos acontecimentos seja a dominante - por exemplo, agrupamentos de eventos que acontecem em um mesmo local.

\section{A ordem em jogo}

Mesmo tendo Gérard Genette direcionado "O Discurso da Narrativa” para uma análise de uma obra literária, os conceitos que menciono acima são perfeitamente aplicáveis a qualquer outra forma narrativa. Não é difícil encontrar exemplos dessas anacronias no cinema, no teatro ou mesmo em histórias em quadrinhos. Aliás, o conhecimento dessas questões beneficia a compreensão de inúmeras narrativas. Porém raramente essas distorções de ordem temporal são exploradas nos jogos. Em geral as histórias contadas em videogames são simples e lineares, não tendo nenhuma alteração da ordem cronológica. Mesmo nas produções em que a história ganha destaque a narrativa mantém essa característica. Esse tipo de linguagem está diretamente ligado ao momento presente, em que o jogador controla um personagem em “tempo real”, respeitando uma seqüência de acontecimentos interligados por causalidade. Criar uma obra onde o jogador controla um personagem noutro tempo que não seja o presente não é tarefa fácil, pois conceitualmente o controle do personagem está diretamente ligado a idéia da ação e reação instantânea ${ }^{4}$. Bem mais simples de se imaginar é o uso de anacronias nos trechos não-interativos dos jogos, que nada mais são do que seqüências audiovisuais sem nenhuma interferência do jogador. Tal recurso seria extremamente eficaz para explicar eventos anteriores ao tempo presente, ou mesmo mostrar como as ações do jogador interferirão no futuro. Mesmo assim, raros são os jogos que utilizam as cenas não-interativas para abordar um tempo que fuja ao da cronologia da história.

\footnotetext{
${ }^{4}$ Podemos encontrar jogos que distorcem a ordem cronológica e que mostram relações entre ações em diferentes pontos temporais, como em "Day of The Tentacle", também de Tim Schaffer, ou mesmo o recente "Onimusha 3". Porém em ambos os jogos a distorção do tempo faz parte da diegése, pois tratam-se de histórias sobre viagens no tempo, em que algo feito no
} 
"Full Throttle" inicia a história num tempo posterior ao da história, com uma locução que indica que a narração é feita por alguém que viveu os fatos e conta o que se passou. Após essa locução introdutória, feita pelo próprio Ben, retornamos no tempo em um salto com alcance indeterminado. Porém não se trata exatamente de uma analepse, pois jamais esse instante inicial em que é feita a locução é recuperado. Por outro lado, esse início num tempo que não é aquele em que vamos vivenciar a aventura é muito inovador para a época em que foi apresentado, além de trazer questões que serão novamente abordadas quando tratarmos das questões do modo e da voz.

Estrutura narrativa semelhante à apresentada por "Full Throttle" é utilizada no game "Deus da Guerra" (2004), com a diferença que desta vez as cenas não-interativas retrocedem temporalmente em analepses heterodiegéticas parciais que vão contando eventos que explicam a história pregressa do personagem que controlamos. Do mesmo modo, a narração tem início num tempo posterior ao da história que vamos vivenciar, mas desta vez, ao final do jogo reencontramos esse ponto inicial: analepse completa. "Deus da Guerra" é de longe uma das mais competentes formas de narrar uma história num jogo, mas é claro que a contribuição da estrutura proposta nos jogos de aventura dez anos antes foi uma das grandes colaborações para que a narrativa dos jogos se desenvolvessem. Porém nos trechos interativos de "Deus da Guerra" o enredo elaborado se dilui e o controle que o jogador exerce no herói se restringe à rápida manipulação de botões que disparam golpes de espada ao enfrentar inimigos que tentam abatê-lo e o acionamento de alguns dispositivos espalhados pelos caminhos trilhados por ele. O mesmo não acontece em "Full Throttle", que por não ter características de jogo de ação, mantém o enredo como o principal dos elementos que estabelecem os desafios do jogo.

Apesar dos exemplos de "desordens temporais" encontrados em jogos, a presença de passado enquanto controlamos determinado personagem interfere num futuro quando controlamos outro personagem. 
anacronias ainda é rara e tímida, distantes do verdadeiro potencial oferecido por essa nova mídia. Imagino que tais recursos, tão eficazes em quaisquer formas narrativas, dariam aos autores de jogos possibilidades inéditas que os levariam à criação de obras muito mais ricas.

\subsection{DURAÇÃO}

Numa narrativa temos o tempo da história e o tempo que se leva para contá-la. Na literatura não podemos medir com exatidão a duração de uma narrativa, diferente do que acontece no cinema ou na música, e não é possível fixar uma velocidade normal de execução. O tempo da leitura é sempre variável.

"Grau zero", ou ponto de referência, é a isocronia rigorosa, a coincidência entre o tempo da história (sucessão diegética) e da narrativa. Na literatura poderíamos atribuí-la um diálogo sem intervenção do narrador e sem elipses - uma espécie de igualdade entre o segmento narrativo e o fictício. Ainda assim, esse não seria um indicador temporal rigoroso, já que não recria a velocidade com que as palavras foram pronunciadas. Por essa impossibilidade métrica na literatura renuncia-se medir as variações de duração em relação a uma inacessível igualdade de duração entre narrativa e história. Assim, a velocidade da narrativa é definida pela relação entre a duração da história, medida em unidade de tempo, e uma extensão espacial - o texto -, medido em linhas ou páginas. A narrativa isocrônica jamais poderia existir na literatura.

Uma narrativa pode passar sem efeitos de anacronias, mas jamais poderá existir sem efeitos de ritmos - ou anisocronias.

Genette verifica os efeitos do ritmo na narrativa proustiana - claro que tal estudo é sempre 
desenvolvido com pouca precisão, pois o tempo diegético quase nunca é indicado com rigor e constata que há um afrouxamento progressivo da rapidez da narrativa; a cada vez aumentase a presença de longas cenas que cobrem apenas uma duração curta da história. Esse afrouxamento é compensado pela presença cada vez maior de elipses, criando uma narrativa constituída de enormes cenas separadas por lacunas temporais.

Existem gradações contínuas entre a velocidade infinita que criaria uma lacuna na temporalidade diegética - a elipse - e a absoluta lentidão - a pausa descritiva. A tradição romanesca resume essas gradações em apenas quatro movimentos narrativos: os extremos elipse e pausa descritiva; cena, que convencionalmente teria igualdade entre o tempo da narrativa e o da história; e a narrativa sumária, que é uma forma de movimento de grande adaptabilidade de regime, cobrindo todo o campo entre a cena e a elipse.

Gérard Genette sugere fórmulas que exemplificam esses quatro movimentos narrativos: $\mathrm{TH}=$ Tempo da História, $\mathrm{TN}=$ Tempo convencional da Narrativa (pseudotempo).

$$
\begin{aligned}
& \text { Pausa: } \mathrm{TH}=\mathrm{n}, \mathrm{TN}=0, \log \mathrm{TN} \infty>\mathrm{TH} \\
& \text { Cena: } \mathrm{TN}=\mathrm{TH} / \mathrm{TN}>\mathrm{TH} \text {, seria uma cena retardada } \\
& \text { Sumário: } \mathrm{TN}<\mathrm{TH} \\
& \text { Elipse: } \mathrm{TN}=0, \mathrm{TH}=\mathrm{n}, \log \mathrm{TN}<\infty \mathrm{TH}
\end{aligned}
$$

Pausa - A pausa em geral é um instante atemporal onde o narrador detalha algum elemento relevante à história. Genette constata que na narrativa proustiana a descrição não determina nunca uma pausa narrativa ou uma suspensão da história. A descrição feita por Proust não congela a ação, mostrando uma paragem contemplativa do próprio personagem. Assim, a pausa proustiana deixa de ter o caráter passivo e repousante, transformando-se numa atividade intelectual que acontece sem que o tempo seja suspenso. A descrição se reabsorve em 
narração.

Cena - Na narrativa romanesca existia a oposição entre cena detalhada e narração sumária; tal confronto revelava uma oposição entre conteúdo dramático e não-dramático. Em Proust a totalidade do discurso narrativo poderia ser definido como Cenas.

Narrativa Sumária - Narra em alguns parágrafos ou algumas páginas vários meses ou anos sem pormenores da ação. Até o fim do século XIX a narração sumária era a forma tradicional de transição entre duas cenas. Em Proust a redução narrativa nunca passa por esse tipo de acelerações.

Elipse - As elipses podem ser:

determinadas, ao indicar-se a duração do salto pela linha cronológica diegética; indeterminadas, quando esse salto permanece sem definições de duração.

Do ponto de vista temporal, podemos elencar as elispes deste modo: explícitas, que, determinadas ou não, procedem por indicação do lapso do tempo que elidem; implícitas, cuja presença não é declarada na narração; hipotéticas, que posteriormente revelam uma analepse.

Jogando com a duração

Se o cinema difere da literatura ao determinar com exatidão o tempo de execução de uma narrativa, podemos neste sentido dizer que, em relação à duração, a narrativa interativa dos videogames está mais próxima da literatura do que do cinema. Num jogo raramente poderemos determinar um tempo único para sua conclusão. Assim como a literatura depende da velocidade de cada leitor, num jogo esse tempo dependerá de fatores como habilidade, interesse, raciocínio etc, que poderão variar de jogador para jogador. Com exceção dos trechos não-interativos, que procedem como seqüências de cinema comuns, o jogo sempre 
dependerá de fatores ligados a características de cada jogador.

Por outro lado, se na literatura a isocronia é algo hipotético, por mais que um jogo tenha a duração variável, seu tempo é quase sempre isocrônico. Isso porque estamos numa realidade simulada, e o herói controlado pelo jogador divide com ele o mesmo espaço de tempo contínuo (durante cada fase). Entretanto, essa percepção de isocronica pode ser desfeita ao ficarem explícitas irregularidades relacionadas à passagem de tempo. Em qualquer "fase" de "Full Throttle" em que o herói deve atingir determinado objetivo estaremos num período do dia determinado pela história; se realizarmos cada missão num espaço de tempo de duas horas, no máximo (o que se estima que aconteça), a isocronia funciona. Porém, se ficarmos 24 horas "presos" numa das fases do jogo, o tempo terá corrido no universo diegético sem que o dia virasse noite ou vice-versa. Esse tipo de distorção acaba não ficando evidente porque o tempo médio que um jogador permanece numa fase do jogo não atinge uma duração que a explicite. Tentando oferecer uma solução para esse "bug" diegético jogos mais preocupados com uma simulação da realidade forjam a rotação da terra, fazendo o sol nascer e se pôr. “GTA-Vice City" (2002), por exemplo, é ambientado numa cidade onde os dias e noites passam, porém a duração de um ciclo não é de 24 horas, mas de 24 minutos. Evidentemente a relação entre o tempo da narrativa e o da história se afasta do "grau zero", mas essa aceleração do tempo diegético não transforma a narrativa em sumária, pois os eventos são contínuos, e a aceleração temporal pouco afeta a estrutura narrativa. A diferença entre "Vice City" e "Full Throttle" no modo como lidam com o tempo está na importância que o período em que os eventos acontecem tem na história. Enquanto em "Vice City" o horário em que as missões são realizadas não tem grande importância, em "Full Throttle" esses horários são elementos fundamentais. 
Na literatura, para que um leitor "complete" determinado texto, ele deverá apenas seguir um percurso textual em sua totalidade. Completar um jogo está ligado ao cumprimento de objetivos pré-determinados como encontrar a solução de um problema, eliminar ou vencer um personagem específico, ou mesmo percorrer um caminho desviando de obstáculos. Por isso, mais do que a variação do tempo narrativo, um jogo poderá oferecer uma livre transição entre movimentos narrativos distintos (dependendo das opções do jogador e desde que isso tenha sido planejado pelo autor).

Em "Full Throttle", por exemplo, nos trechos interativos da história, temos que cumprir missões indicadas pelas cenas não-interativas. A primeira delas começa logo apos o herói recobrar a consciência, e devemos fazê-lo conseguir pegar a estrada e ir na direção de seus companheiros de gangue. Com conhecimento desse macro-objetivo, devemos solucionar pequenos enigmas que vão nos levando ao objetivo principal desse trecho. Primeiro devemos conseguir tirar Ben de dentro de uma grande lata de lixo que fica atrás de um boteco de estrada; em seguida, podemos indicar o caminho que o herói deve seguir até encontrar sua motocicleta. Porém suas chaves foram roubadas e precisamos encontrá-las para que o herói parta em busca de seus parceiros. O boteco está trancado e só com nosso comando para que Ben arrombe a porta é que será possível levá-lo para dentro. Podemos procurar a chave por todo o bar; também é possível fazer com que Ben converse com o barman, tentando conseguir informações sobre o que aconteceu enquanto estava desacordado ou para onde seus amigos foram. Apesar das informações contribuírem para entendermos o que está acontecendo, só com um comando indicando que Ben agrida o barman é que descobriremos onde estão as chaves de sua moto e o que aconteceu de fato. Todas as ações tomadas pelo protagonista, assim como as perguntas que fará aos outros personagens, são escolhidas pelo jogador. Desse modo podemos, ao controlar Ben, transitar entre movimentos narrativos. Enquanto Ben anda de um lado para o outro, executa as ações que indicamos, conversa com outros personagens 
ou mesmo cumpre as nossas solicitações estamos numa cena, mas, se pararmos para contemplar um cenário em busca de pistas ou mesmo ao analisar um simples objeto, teremos transitado para um novo módulo: a pausa. Claro que essa pausa não é uma suspensão do tempo -como a pausa proustiana, comentada por Genette, é uma atividade intelectual -, mas desta vez, dividimos a contemplação com o personagem; aliás, somos nós que determinamos a duração desta pausa. Há também a pausa onde o tempo é suspenso, recurso aliás muito comum em todos os jogos. Nessas pausas totais, o tempo diegético pára de correr - esse recurso pode ser usado ou para comandos que nos retiram da diegése, como nos momentos em que alteramos as configurações do jogo, ou mesmo em ações dentro da história do jogo ao examinar objetos no inventario do herói, ao trocar de arma ou mesmo ao ler alguma informação ou pista fornecida pelo jogo. Em geral essas ações congelam o tempo para que o jogador possa analisar objetos e mapas, deixando-o momentaneamente isento dos perigos. Por outro lado, essa pausa na continuidade temporal durante as pesquisas no inventário e nos mapas, pode deixar de existir e transformar esse momento num novo desafio. A ausência da pausa total em "Resident Evil Outbrake", faz com que o jogador procure as armas e pesquise os caminhos sem que o tempo congele e os inimigos deixem de se aproximar do protagonista.

As elipses em geral estão nas seqüências não-interativas dos jogos, mas não tenho maior preocupação em estudá-las pois funcionam do mesmo modo que no cinema. Provocar uma elipse ao jogar já é um pouco menos provável, mas ainda sim possível. Mas, se considerarmos o uso da tecla "esc", que corta as cenas não-interativas, enviando-nos direto à próxima fase interativa do jogo, podemos dizer que há controle do jogador nas elipses. Esse é o único caso em "Full Throttle" de elipses dentro da interatividade. O uso desse recurso seria algo que teria contribuído para o próprio conceito da jogabilidade. Anos depois de "Full Throttle", em “Grim Fandango" (1998), também criado por Tim Schaffer, os eventos disparados por nossos 
comandos são exibidos na integridade apenas uma vez; todas as repetições são evitadas e, com o uso de fade-in e fade-out, a história dá um salto no tempo sem precisarmos assistir mais vezes ao evento que já conhecemos. Com esse recurso o jogo ganha agilidade.

Não encontro exemplos de narrativa sumária nos momentos interativos de qualquer jogo. Porém acredito que isso não seja uma limitação da linguagem narrativa dos jogos; é apenas algo que não foi planejado pelos criadores de jogos. Mesmo o uso da pausa, da elipse ou da cena, ainda podem ser recursos muito mais explorados, o que dará aos game designers novos horizontes.

\subsection{FREQÜÊNCIA}

No terceiro capítulo de "O Discurso da Narrativa", Genette estuda as relações temporais de freqüência entre narrativa e diegése, assunto pouco estudado pelos teóricos do romance. Um acontecimento pode acontecer mais de uma vez, reproduzindo-se inúmeras vezes; entretanto, é evidente que nenhuma ocorrência é materialmente por completo idêntica às outras - cabe ao discurso narrativo contar esses episódios por repetições narrativas que eliminam de cada ocorrência tudo o que lhe pertence de específico e só conserva o que partilha com as outras.

Entre as capacidades de repetição de acontecimentos narrados (da história) e dos enunciados narrativos (da narrativa). Estabelece-se um sistema de relações que se dividem, a priori, em quatro tipos distintos:

1 - Contar uma vez aquilo que se passou uma vez $(1 \mathrm{~N} / 1 \mathrm{H})$. A singularidade do acontecimento responde à singularidade do acontecimento narrado. Genette chama esse 
recurso de narrativa singulativa.

2 - Contar $n$ vezes aquilo que se passou $n$ vezes $(\mathrm{nN} / \mathrm{nH})$. As repetições da narrativa respondem segundo uma correspondência isônica às repetições da história.

3 - Contar n vezes aquilo que se passou uma vez somente $(\mathrm{nN} / 1 \mathrm{H})$. Genette nomeia esse recurso de narrativa repetitiva.

4 - Contar numa única vez aquilo que se passou n vezes $(1 \mathrm{~N} / \mathrm{nH})$, em que uma única emissão narrativa assume conjuntamente várias ocorrências do mesmo acontecimento. Genette dá o nome de narrativa iterativa a esse recurso.

Enquanto os dois primeiros tipos respondem exatamente a uma relação de igualdade entre os acontecimentos da história e da narrativa, a narrativa repetitiva e a iterativa criam relações de disparidade que se transformam em recursos da narrativa.

\section{A narrativa repetitiva}

Crianças gostam que lhes contem várias vezes a mesma história; tal característica não é privilégio da infância. Esta forma pode parecer puramente hipotética e sem qualquer pertinência literária, mas Genette nos relembra que textos modernos utilizam a repetição da narrativa, que pode, além de contar um mesmo episódio mais de uma vez com variantes estilísticas, acrescentar variações de ponto de vista. Mesmo assim, Gérard Genette não se estende nesse tipo de relação, focando-se no quarto tipo, bem mais comum às narrativas literárias.

\section{A narrativa iterativa}


Na narrativa clássica os segmentos iterativos estão quase sempre em estado de subordinação funcional em relação às cenas singulativas. A função da narrativa iterativa está bastante próxima da descrição. No romance tradicional a descrição está, assim como a narrativa iterativa, a serviço da narrativa propriamente dita (singulativa).

Flaubert, em Madame de Bovary, é o primeiro romancista a emancipar a iteração, dando a ela autonomia e amplitude inéditas. Entretanto, Gérard Genette ressalta que nenhum outro romance fez do iterativo uso comparável à de Recherche du Temps Perdu, em que o campo temporal coberto pelo segmento iterativo por várias vezes é maior do que o da cena em que se insere: o iterativo abre um tipo de parêntese que passa a ser chamado de Iterações Generalizantes ou Iterações Internas. Outro tipo menos clássico de passagem ao iterativo no decorrer de uma cena singulativa é tratar parcialmente de forma iterativa a própria duração da cena. Genette chama esse segundo tipo de iteração interna ou sintetizante; a silepse iterativa se exerce não sobre uma duração exterior mais vasta, mas sobre a duração da própria cena. A mesma cena pode conter os dois tipos de iteração, que podem se confundir a ponto de o leitor já não poder distingui-los.

Há também o pseudo-iterativo, um recurso em que se apresenta cenas singulativas como iterativas, ao passo que a riqueza e a precisão dos pormenores fazem com que nenhum leitor suponha que elas aconteceram realmente várias vezes. Tal recurso é usado como figura de retórica na narrativa clássica. Já em Proust, mais do que isso, os instantes têm a tendência de se agrupar e se confundir.

O simples fato da recorrência não define a iteração. A repetição deve ser regular e obedecer uma lei de freqüência; esta lei tem que ser destrinçável e formulável - logo, previsível nos 
efeitos. Toda a narrativa iterativa é uma narração sintética dos acontecimentos produzidos e reproduzidos no decorrer de uma série iterativa composta por certo numero de unidades singulares.

A série é definida pelos limites diacrônicos e pelo ritmo de recorrência das unidades que as constituem. O primeiro traço é a determinação e o segundo, a especificação. A amplitude diacrônica será a extensão.

A determinação dos limites diacrônicos de uma série pode permanecer implícita, sobretudo ao tratar de um acontecimento ilimitado (o nascer do sol, por exemplo). Pode ainda ser indefinida ou definida. A especificação também pode ser indefinida (por vezes... certos dias...) ou pode ser definida (todos os dias... todos os domingos...). Existem especificações complexas: formadas por leis de recorrências que se sobrepõem, podendo encaixar várias unidades iterativas. Por exemplo, uma especificação como "todos os meses de maio", conjugada com outra especificação simples, “todos os sábados”, originando a especificação complexa "todos os sábados do mês de maio". A extensão de algumas unidades iterativas possuem amplitude bastante para constituir objeto de uma narrativa desenvolvida. Nesses casos os meios de diversificação (de variação) das determinações e especificações internas da série iterativa oferecem possibilidades que intervêm para "concretizar a narrativa".

Além da determinação marcar os limites exteriores de uma série iterativa, pode também segmentar as suas etapas dividindo-as em sub-séries que funcionam como variantes de unidade sintética. Porém devemos distinguir os episódios singulativos intercalados num segmento iterativo dentre aqueles que têm uma função determinada e aqueles que não têm. $O$ acontecimento pode ser uma simples ilustração sem modificar em nada a iteração. 
A narrativa iterativa, por intermédio das determinações e especificações internas, pode integrar a diacronia na sua própria progressão temporal e utilizar as modificações trazidas ao seu desenvolvimento pelo tempo decorrido. Os pontos impossíveis de serem classificados como singulativos e tampouco como iterativos, por não terem relação temporal assimilável, encontram-se nos chamados segmentos neutros que podem ser de três espécies:

- Excursos discursivos no presente; segmentos que evidentemente têm o status de extra-narrativos.

- Diálogos sem verbos declarativos (diálogos diretos, expostos sem transições entre as partes), que eventualmente podem ser reduzidos a uma única réplica.

- Segmentos mistos, que interpõem-se entre iterativo e singulativo imperfeitos, cujo valor aspectual não é determinável. Sem dúvida o mais sutil dos segmentos neutros.

O jogo com o tempo

Não é possível caracterizar o teor temporal de uma narrativa sem considerar todo o conjunto de relações estabelecido entre sua temporalidade e a da história que conta. Em alguns momentos de "Recherche", por exemplo, a passagem de tempo se disfarça sob as aparências de repetição. Genette diz que papel do analista é, apos a descoberta do processo, ver como a motivação invocada funciona na obra como meio estético. Minha tarefa aqui é tentar fazer o mesmo, e encontrar as analogias entre a freqüência narrativa descrita por Genette e a freqüência narrativa nos games .

Dos quatro tipos de sistemas narrativos divididos por Genette - singulativo, isônico, de repetição e iterativa, os dois primeiros seguem a mesma fórmula $<\mathrm{nN} / \mathrm{nH}>$; o número de vezes que uma ocorrência foi verificada é o mesmo número de vezes a ser contado. Minha 
tendência inicial era assumir que esses dois tipos de freqüência narrativa resumiam a grande maioria dos momentos interativos ${ }^{5}$ das produções de jogos eletrônicos. Isso porque, como já mencionei anteriormente, um dos fundamentos da linguagem dos games é o conceito de momento presente durante o controle do avatar, simulando que tudo está acontecendo no exato momento que o jogador comanda cada uma das de suas ações. Porém, um olhar mais atento desvenda o uso da narrativa de repetição para simular a própria narrativa singulativa.

Em "Full Throttle" quando é necessário o cumprimento de uma tarefa específica podemos tentar e falhar infinitas vezes até sermos bem sucedidos e desencadear um novo status. Na primeira fase do jogo, por exemplo, depois de receber o objetivo de encontrar peças para a moto quebrada, temos três objetivos primários: conseguir um garfo de motocicleta, um maçarico e gasolina. Para cada um desses objetos teremos um enigma a ser desvendado. Para conseguir o maçarico precisamos, exatamente nesta ordem, levar Ben até uma casa onde uma janela emana flashes de luz, bater na porta e aguardar o exato momento em que o proprietário usa o olho mágico; então Ben deve chutar a porta, derrubando o homem. O maçarico está no andar debaixo, ao lado das esculturas de metal. Mas se ao invés disso, fizéssemos Ben bater na porta mas não chutar no momento oportuno, o proprietário apenas gritaria e voltaria ao seu trabalho. Isso não quer dizer que o jogo foi perdido e que deveríamos recomeçá-lo; ao contrário, Ben pode retornar ao local de qualquer "missão" incompleta e repeti-la até que o objetivo seja finalmente atingido. Enquanto isso não acontecer toda missão incompleta volta automaticamente ao seu status inicial, repetindo cada passo até ser concluída. O roteiro é engenhosamente escrito e as repetições acabam nos iludindo com a idéia de que é mais uma tentativa do protagonista e de que não estamos revendo uma mesma ação $n$ vezes, mas sim

\footnotetext{
${ }^{5}$ Os trechos não interativos dos jogos, por funcionarem como tradicionais seqüências cinematográficas, são muito mais livres para utilizar as variações narrativas de freqüência como o próprio cinema o faz. Acredito que questão maior encontra-se ao procurar esses recursos no jogo em si durante o controle exercido pelo interador.
} 
que essa ação acontece $n$ vezes $(\mathrm{nN} / \mathrm{nH})^{6}$.

Sem dúvida a narrativa iterativa cobre a grande maioria dos romances e por isso mesmo recebe um estudo mais detalhado no livro de Genette. Nos jogos, entretanto, acredito que a narrativa de repetição também é importante. A repetição esta presente na simulação de uma temporalidade contínua, como exemplifiquei em "Full Throttle", ou ainda na utilização comum à maioria dos games do "salva jogo". Com esse recurso, sempre que uma ação mal sucedida acontece, o jogador pode reiniciar no momento em que o jogo foi salvo e repetir a ação até que ele obtenha o resultado necessário para o progresso da história. De fato não há grande diferença conceitual entre esses dois modos repetitivos; tanto "Full Throttle" como os jogos que permitam o "salva jogo", utilizam-se da repetição para possibilitar novas tentativas. Mas se a repetição fosse aliada a novos pontos de vista a cada vez que a narrativa regressasse, como Genette menciona referindo-se aos romances modernos, os jogos apresentariam novas possibilidades narrativas, e tal recurso, aliado à interatividade própria da mídia, possibilitaria desdobramentos impensáveis para a literatura, o teatro ou o próprio cinema.

A narrativa iterativa parece estar distante dos jogos, mas acredito que há uma forte relação entre a iteração e a repetição dos jogos de ação, em que o protagonista enfrenta várias vezes inimigos idênticos ou desvia do mesmo obstáculos por fases inteiras. Apesar da aparente isonomia $(\mathrm{nN} / \mathrm{nH})$ dessa relação de freqüência, parece-me que aqui a repetição funciona como mero enunciado que nos informa que o herói passou por muitos desafios até chegar ao final daquele módulo. Em um jogo de ação como "Mário Bros", o protagonista precisa superar ou derrotar uma infinidade de opositores iguais, repetindo as mesmas ações. Ao final da fase, não

\footnotetext{
${ }^{6}$ Vale lembrar que no caso de um jogo a ação já está pré-programada na memória e exatamente a mesma ação será repetida, respondendo a um mesmo comando armazenado em um trecho da mídia. Num livro, para descrever uma ocorrência repetitiva não seriam usadas as mesmas palavras e mesmo que fossem, não estariam na mesma página.
} 
há como saber o numero certo de vilões derrotados. Sugiro que o número de obstáculos vencidos não representaria necessariamente o número exato de obstáculos na história, servindo apenas de representação para indicar que o protagonista superou um grande número de dificuldades. Teríamos então uma nova fórmula: $\mathrm{n} 1 \mathrm{~N} / \mathrm{n} 2 \mathrm{H}$, onde $\mathrm{n} 1<\mathrm{n} 2$. Porém acredito que uma nova nomenclatura seria necessária para se fazer mais eficiente a classificação dos games e, portanto, um estudo mais detalhado seria requerido. Isso me distanciaria do foco inicial que propus a manter nessa pesquisa.

\subsection{MODO}

Gramaticalmente modo é o nome dado às diferentes formas do verbo empregadas para afirmar mais ou menos, e para exprimir diferentes pontos de vista. Sob esta definição é possível que se conte "mais" ou "menos" daquilo que se conta, e contá-lo segundo um ou outro "ponto de vista". A função de uma narrativa não é dar uma ordem, formular um desejo ou enunciar uma condição, mas simplesmente contar uma história relatando os fatos reais ou fictícios que a construíram. O seu modo único só poderia ser o indicativo, a menos que houvesse um alargamento da metáfora lingüística. Porém há diferenças nesse grau de afirmação que são expressadas por variações modais, seja o infinito e o conjuntivo do discurso indireto em latim ou o condicional, marcando uma informação sem confirmação. Analogicamente o modo narrativo também tem seus graus e pode fornecer ao leitor mais ou menos detalhes, e de forma mais ou menos direta. É pelo modo que o narrador escolhe tanto a graduação da distância daquilo que se conta quanto a credibilidade da informação passada de acordo com as capacidades de conhecimento das diferentes partes integrantes da história, tomando uma certa perspectiva que determina o que se chama de visão ou ponto de vista. Distância e perspectiva são as duas modalidades essenciais que regulam a informação 
narrativa. Genette percorre alguns momentos na história da teoria literária, que tratam desse problema.

A questão da distância é abordada pela primeira vez por Platão no terceiro livro d’A República. São opostos dois modos narrativos: um em que o poeta fala em seu próprio nome, sem tentar nos iludir que é outro quem fala - a narrativa pura; outro, em que o poeta faz parecer que quem fala é um personagem da história contada. Platão chama esse estilo de imitação ou mimese, e para explicitar essa diferença utiliza o termo diegése para definir o outro.

Na narrativa pura uma cena dialogada diretamente torna-se uma narrativa mediatizada pelo narrador - as falas de cada personagem se misturam juntando-se num discurso indireto. Genette assume provisoriamente que a narrativa pura é mais distante do que a narrativa mimética, por dizer menos e de forma mediada.

No final do século XIX e início do XX, Henry James e seus discípulos abordaram o assunto mostrando a diferença entre mostrar showing e contar telling. $\mathrm{O}$ ato de mostrar, de caráter ingenuamente visual e perfeitamente ilusório, era criado pela imitação ou representação narrativa. No entanto, ao contrário da representação dramática, a narrativa não pode imitar ou mostrar a história que conta; no máximo pode contar de maneira mais detalhada e precisa, criando assim a ilusão da mimese. Para James, a linguagem significa e não imita.

Existe uma diferença entre a "narrativa de acontecimentos" e a "narrativa de falas". 
A “narrativa de acontecimentos" sempre transforma o não-verbal em verbal e, portanto, sempre será uma ilusão de mimese. A grande quantidade de informação na narrativa e a ausência (ou presença mínima) do narrador caracterizam uma forma de contar em que se diz o mais possível sem mostrar que é o narrador quem conta. Não à toa, nas narrativas que "mostram" (showing), existe uma dominância da cena.

É possível entender a oposição do mimético e do diegético pela relação entre informação e informador. A quantidade de informação e a presença do informador estão na razão inversa a mimese é definida por um alto grau de informação e um baixo de informador; a diegése é definida pelo inverso. Essa definição nos reenvia a uma questão temporal: a velocidade da narrativa, pois a quantidade de informação está na razão inversa da velocidade da narrativa. Para os partidários pós-jamesianos do romance mimético a melhor forma narrativa seria aquela em que a história é contada por um personagem na terceira pessoa. Nesse processo o narrador não é um dos personagens, mas adota o ponto de vista como se fosse.

\section{Narrativa de falas}

Se a imitação verbal de acontecimentos não-verbais é uma ilusão, a "narrativa de falas" parece não poder fugir dessa absoluta imitação. Entretanto, podemos distinguir dois estados possíveis nos discursos de personagens: um deles imitado, de fato, como se supostamente pronunciado pelo personagem, e outro narrativizado, tratado como um acontecimento e assumido pelo próprio narrador. Platão tinha a preocupação de conservar um maior grau de detalhamento mesmo no discurso imitado; para isso inseria elementos intermediários em estilo indireto. Isso cria mais uma opção - o discurso transposto, levando-nos aos três estados 
do discurso:

Narrativizado ou contado - o mais distante e redutor dos três.

Transposto - em estilo indireto, um pouco mais mimético do que o discurso contado; esse estado não permite o sentimento de fidelidade literal, pois o narrador interpreta e integra falas a seu próprio discurso. Uma variante é o "discurso indireto livre", em que a economia da subordinação autoriza uma certa emancipação.

Relatado (reportado) - esta é a forma mais mimética dos três estados. Nela o narrador simula uma cessão da palavra às suas personagens. Por suas características miméticas puras é o tipo de discurso massivamente concedido à dicção dramática. A evolução desse estado na literatura permitiu a diluição total do enunciado introdutório entre as falas - o discurso imediato, um discurso relatado levado ao extremo.

A grande diferença entre o discurso imediato e o discurso indireto livre é a postura assumida pelo narrador. No discurso indireto livre o narrador assume o discurso do personagem como se ele falasse por sua voz, enquanto no discurso imediato o narrador dilui-se e o personagem o substitui. Na narrativa proustiana o discurso relatado é interior ao personagem. Claro que o pensamento é um discurso, porém esse discurso é enganador (como qualquer outro) e infiel ao sentimento real do personagem.

Além da opção da focalização narrativa, há um segundo modo de regulação da informação: a perspectiva narrativa, que é definida pela escolha (ou não) de um "ponto de vista" restritivo. Genette faz um levantamento de vários trabalhos teóricos sobre esse assunto, mas constata que todos confundem modo e voz, ou seja, confundem o personagem a partir do qual é orientada a perspectiva narrativa e quem narra a história. Simplificando: havia confusão entre duas instâncias - "quem vê" e "quem fala". 
Seria admissível entender uma tipologia das "situações narrativas" que envolvessem simultaneamente dados de modo e de voz, mas não funcionaria uma classificação como essa sob a categoria unificada do "ponto de vista".

Há um consenso no estabelecimento de uma tipologia dividida em três termos. O primeiro deles corresponde ao que a crítica anglo-saxônica chama de "narrativa de narrador onisciente", simbolizada pela fórmula de Todorov NARRADOR > PERSONAGEM, em que o narrador sabe mais do que o personagem. O segundo tipo trata da narrativa em que o narrador diz somente o que determinado personagem sabe. Esse tipo seria simbolizado pela fórmula NARRADOR = PERSONAGEM. O terceiro é a narrativa objetiva, em que o narrador diz menos do que sabe o personagem, simbolizado por NARRADOR < PERSONAGEM.

Genette rebatiza esses três tipos a partir da focalização; assim, o primeiro tipo passa a ser a narrativa não-focalizada ou de focalização zero. O segundo será a narrativa de focalização interna, podendo ser fixa - com restrição de campo, variável - em que o personagem central muda no decorrer da história, ou múltipla, em que o mesmo acontecimento pode ser evocado várias vezes com alterações de pontos de vistas de personagens diferentes. O terceiro tipo será a focalização externa, em que o herói age à nossa frente sem que possamos partilhar seus sentimentos e pensamentos.

Apesar de a focalização ser essencialmente uma restrição, a decisão da focalização não é obrigatoriamente constante em toda a narrativa. Michel Raimond expõe que os romances de intriga ou aventura baseiam seu ponto de interesse no fato da existência de um mistério. Por 
isso o autor deixa de dizer tudo o que sabe de um momento para o outro. Não é à toa que grande número nos romances de aventura as primeiras páginas são focalizadas externamente. A fórmula de focalização se aplica a segmentos narrativos que podem ser muito curtos.

Não poderíamos falar de uma focalização interna no sentido estrito, pois raramente sua aplicação é totalmente rigorosa. Por princípio esse modo narrativo implicaria um absoluto rigor que não permitiria que o personagem fosse descrito externamente, do mesmo modo como seus pensamentos e sentimentos jamais poderiam ser analisados pelo narrador. A focalização interna só encontraria de fato na narrativa em monólogo interior.

A focalização externa, ao contrário, marca a ignorância do narrador em relação aos pensamentos autênticos do personagem. Mas esse critério não deve criar confusão às instâncias da focalização e da narração, que continuam distintas até mesmo na narrativa da primeira pessoa, quando as duas instâncias são assumidas pela mesma pessoa. O narrador sabe, quase sempre, mais que o herói - mesmo que esse herói seja ele mesmo. A focalização sobre o herói é, para o narrador, uma restrição de campo artificial na primeira ou na terceira pessoa.

\section{Alterações}

Mudanças de focalização isoladas em contextos coerentes são infrações momentâneas ao código que rege o contexto da narração e não colocam em questão a existência desse código. Essas alterações são infrações isoladas e concebíveis de duas formas:

- Dar menos informação do que aquela que seria requerida - omissão lateral, conhecida como paralipse. 
- Dar mais informação do que seria autorizado pelo código de focalização que rege a narrativa; o fornecimento de uma informação que deveria ser deixada de lado - paralepse.

A paralipse pode ser encontrada no mais clássico dos romances policiais - mesmo que seja focalizado pelo detetive investigador, deixa de nos informar todas as suas descobertas até a revelação climática do final. Muitas paralipses são descobertas apenas ulteriormente por revelações feitas pelo narrador.

A paralepse pode ser verificada, por exemplo, numa incursão na consciência de um determinado personagem durante o desenrolar de uma narrativa que vinha sendo estabelecida em focalização externa.

"A narrativa diz sempre menos do que aquilo que sabe, mas faz muitas vezes saber mais do que aquilo que diz", conclui Gérard Genette.

Polimodalidade

O emprego da "primeira pessoa" não implica nenhuma focalização da narrativa sobre o herói. O narrador autobiográfico tem maior autonomia para falar em seu próprio nome do que o narrador em terceira pessoa. $\mathrm{O}$ narrador autobiográfico não responde a qualquer suposta discrição, ao contrário do narrador pessoal.

A opção pela focalização interna do ponto de vista de um personagem ao mesmo tempo explicita sua psicologia e deixa numa completa obscuridade os pensamentos dos demais; assim, acaba por constituir-lhe uma personalidade misteriosa. Incursões na psicologia de personagens que não seja a do herói são indícios de focalização que a narrativa pratica sob 
uma forma hipotética.

A experiência posterior do herói pode ser revelada por expressões como "vim depois a saber...”. Essas intervenções não devem ser atribuídas ao autor onisciente. "Entre a informação do herói e a onisciência do romancista há a informação do narrador”, define Genette.

Criando uma analogia entre a música e a narrativa, o sistema tonal equivaleria ao sistema modal. Um sistema narrativo livre poderia ser chamado de amodal quando as infrações (paralipses e paralepses) alterassem o código que rege a narrativa, estendendo a analogia ao atonal, em que nenhum código prevalece. Genette traça tal paralelo para mencionar que "Recherche" estaria num estágio intermediário, a polimodalidade.

O modo do jogo

$\mathrm{O}$ modo narrativo num jogo funciona com funções semelhantes às que estabelecem a distância e perspectiva abordadas por Genette. O jogo é uma forma de narrativa dramática e, portanto, não se trata de imitação; a narrativa de um jogo é diegética ${ }^{7}$. Do ponto de vista da distância, os jogos funcionam de forma semelhante ao teatro e ao cinema, mas acredito que os jogos passam a potencializar maiores variações narrativas em relação à perspectiva.

A confusão entre modo e voz a que Gérard Genette se refere em seu livro não é privilégio da literatura; a mídia especializada em jogos eletrônicos compartilha essa mesma confusão. A visão de um jogo é definida como em primeira pessoa quando enxergamos a partir dos olhos

\footnotetext{
${ }^{7}$ Salvo jogos que não fazem uso de imagens em movimento - como os adventures em texto, em que o jogador resolve os problemas propostos de forma escrita, podendo haver em seu enunciado diálogos miméticos.
} 
do herói ou em terceira pessoa, ao visualizarmos o herói. Tal terminologia acabou por se tornar praxe em qualquer resenha que descreve um jogo. Mas na realidade, ao determinar a visão não estamos tratando da "pessoa"(voz), mas sim da perspectiva (modo).

Não é difícil notar esse equívoco ao voltarmos a "Full Throttle", que é iniciado com uma longa narração em "primeira pessoa" que desencadeia os acontecimentos da história do jogo. O narrador é o próprio herói, o motoqueiro Ben. Se tomarmos como base a nomenclatura tradicional dos críticos de videogame, "Throttle" seria definido como jogo em "terceira pessoa", apesar de a narrativa ser explicitamente realizada em "primeira pessoa". O ideal seria definir a visão pelos critérios de focalização que tratam do ponto de vista. O uso dos termos definidos por Genette - narrativa não-focalizada, narrativa de focalização interna $\mathrm{e}$ narrativa de focalização externa - seriam bem mais apropriados. Não há polêmica ao afirmar que "Full Throtle" é uma narrativa de focalização externa em primeira pessoa.

Se ficássemos presos aos termos primeira e terceira pessoa para definirmos a visão dos jogos, teríamos problemas em tentar distinguir um jogo como "Throttle" - em que o jogador acompanha a aventura enxergando o personagem principal sempre à sua frente - de um jogo como "Black or White", em que o jogador assume o controle de uma deidade que determina os acontecimentos de um povoado. Usando o método tradicional, estaríamos falando de dois jogos em terceira pessoa, e deixaríamos de lado características de focalização importantes. Usando a classificação proposta por Genette, classificaríamos "Throttle” como um jogo com focalização externa e "Black or White" como um jogo de focalização de grau zero - ou melhor ainda, nesse caso: narração onipresente. Jogos como "Doom" ou "Riven", aos quais a visualização em primeira pessoa são atribuídas, na verdade são jogos com narrativa de focalização interna. 
Essa confusão nasce do modo como uma história é contada num jogo eletrônico. Se na literatura a distinção entre "quem vê" e "quem conta" é mais explícita, o mesmo não acontece nos jogos. A presença do narrador num jogo é camuflada para que a impressão de que o jogador está vivendo aquela aventura em tempo real seja preservada ${ }^{8}$. Mas jamais poderíamos dizer que não há narrador numa história contada num videogame. Em teatro, cinema e literatura há sempre alguém contado a história de maneira mais ou menos aparente. O que acontece num jogo é que a história não é contada, ela é previamente criada para que o narratário (jogador) não a escute ou a assista, mas a descubra. Por esse prisma fica claro que a decisão do modo em que o jogador visualizará a história é da narração; o narrador, então, não é "quem conta", mas é "quem deixa saber".

A determinação da focalização tem um poder de definição muito maior do que o modo com que o jogador visualiza o jogo. Ao jogar "Full Throttle", por mais que o usuário se envolva com a aventura, não podemos dizer que o jogador conheça os pensamentos e sentimentos do herói (salvo nos momentos em que isso é verbalizado). Já num jogo de focalização interna, como "Riven" ou mesmo "Doom”, poderíamos imaginar que também não compartilhamos nenhum sentimento ou pensamento do personagem, pois tal informação jamais é mostrada. Os jogos baseados na focalização interna validam-se dessa característica focal como recurso imersivo ${ }^{9}$, fazendo o jogador mergulhar na aventura como se fosse ele mesmo quem estivesse vivendo naquele mundo virtual. Para que a imersão seja criada, o "personagem" é esvaziado a ponto de existir uma fusão entre o narratário e o herói. Desse modo os pensamentos e sentimentos do herói já não são apenas partilhados com o jogador, pois os sentimentos e

\footnotetext{
${ }^{8}$ Algo semelhante acontece no cinema, mas por maior que seja a imersão do expectador ao assistir a um filme, ele não sente que está vivendo aquela história ou que possa influenciar seu desenrolar.
} 
pensamentos de herói passam a ser os do próprio jogador. Vejo aqui uma das grandes possibilidades narrativas dos jogos, pois nenhuma outra mídia narrativa possibilita tal maneira de contar histórias.

As alterações de focalização, que provocam infrações ao código regente da narração, também ocorrem nos jogos. Em geral essas infrações acontecem nas cenas não-interativas (cut scenes) e funcionam para dar informações necessárias ao jogador, para que tome conhecimento das missões que deverão ser cumpridas. "Full Throttle" é orientado por uma focalização externa no herói. Mas logo no início, após sua locução introdutória, assistimos a um diálogo dentro de uma limusine entre o dono da companhia e seu braço-direito. Ben não estava presente e jamais poderia saber o que se passou naquele carro, pois todos os personagens, incluindo o motorista, morrem durante a história sem conversar com o herói sobre o episódio. Essa cena é indispensável para que o jogador entenda o que deverá fazer, e a utilização da paralepse é um recurso eficaz. Por outro lado, acredito que todas as informações escondidas ao jogador são paralipeses - um determinado objeto que o herói se recusa a analisar, ou mesmo um caminho que não pode ser seguido em "Full Throttle"; um prédio que não permite que o personagem nele entre em "Vice-City", ou até uma porta trancada em "Doom" são exemplos dessa omissão de informações.

Um jogo não precisa manter a focalização por toda sua duração, podendo mudar a focalização interna para externa, ou mesmo de um personagem para outro. "Dark Forces II - Jedi Knight" era um jogo de focalização interna que permitia, ao apertar-se uma tecla, que o jogador mudasse a "câmera" para a focalização externa. Um jogo adventure, semelhante a "Full Throttle", de nome "Gabriel Knight - The Beast Within", alternava fases onde o jogador

\footnotetext{
${ }^{9}$ Imersão é um termo originário na metáfora que sugere que um receptor (leitor, expectador ou jogador) mergulha no universo artificial da obra.
} 
controlava (sempre em focalização externa) dois personagens diferentes. Tal maleabilidade da focalização usada em conjunto com a freqüência repetitiva - comentada anteriormente - traria aos autores de jogos possibilidades muito ricas na criação de novas obras.

\section{$2.5 \mathrm{VOZ}$}

A voz cuida das questões da ação verbal em suas relações com todos aqueles que participam da atividade narrativa, incluindo quem a relata e quem participa passivamente, não se restringindo a quem sofre ou provoca a ação apenas. A lingüística levou certo tempo para tratar da "subjetividade da linguagem", que é a análise dos enunciados, e da relação entre eles e sua instância produtiva, hoje chamada de enunciação. A instância produtiva do discurso narrativo é definida pelo termo narração.

Há uma confusão ao se pensar que narrador e autor são a mesma pessoa. O próprio narrador é um personagem fictício numa narrativa de ficção, mesmo que esse narrador seja diretamente assumido pelo autor.

A instância narrativa é variável no decorrer de uma obra. As aventuras de Ulisses, por exemplo, são narradas por dois diferentes narradores. Assim, a situação narrativa é composta por uma série de relações entre o ato de narrar, seus protagonistas, suas determinações espaciais e temporais, etc. 
Tempo de narração

Uma história pode ser contada sem que o local onde se passa seja especificado, mas é praticamente impossível não situá-la no tempo em relação à narração. Necessariamente, essa história será contada num tempo verbal do presente, do passado ou do futuro. Genette sugere que talvez as determinações temporais seriam manifestamente mais importantes do que as determinações espaciais, lembrando que na literatura o lugar narrativo, onde o narrador conta a história, raramente é especificado e quase nunca pertinente.

A principal determinação temporal da instância narrativa é sua posição em relação à história, o que obriga o narrador a situá-la entre passado, presente e futuro. Sob esse aspecto, pode-se classificar quatro tipos de narração:

- Ulterior - a posição clássica da narrativa no passado, sem dúvida a forma mais freqüente.

- Anterior - a narrativa preditiva, geralmente no futuro, mas que também pode ser conduzida no presente.

- Simultânea - a narrativa é contemporânea à ação e, por isso, no presente.

- Intercalada - entre os momentos da ação.

A narrativa intercalada é, em princípio, o tipo mais complexo, por se tratar de uma narrativa com instâncias distintas. A história e a narração podem enredar-se a ponto de a segunda reagir sobre a primeira. A proximidade entre a história e a narração produz um atrito entre o ligeiro afastamento temporal da narrativa de acontecimentos e a simultaneidade na exposição dos sentimentos e pensamentos - o quase monólogo interior e o relato feito depois. "Aí o narrador 
é ao mesmo tempo ainda o herói”, conclui Genette.

A narração simultânea é, em princípio, a mais simples, pois há uma rigorosa coincidência entre a história e a narração, eliminando toda a interferência e jogo de tempo. A distância temporal entre a história e a narração desaparece numa transparência total da narrativa. O uso do presente favorece a absoluta transitividade da narração. Porém isso se inverte se o acento é posto na própria narração, como os "monólogos interiores". A coincidência passa a jogar em favor do discurso e é a ação que parece reduzir-se a um estado de simples pretexto.

A narração anterior até hoje é o menos comum dos quatro tipos. Em geral é usada no gênero profético e pós-datam a instância narrativa, implicitamente posterior a sua história. Em geral são preditivas em relação a sua instância narrativa imediata, mas não em relação à última instância.

A narração ulterior engloba a grande maioria das narrativas produzidas. O emprego de um tempo no pretérito é usado sem que seja necessário indicar a distância temporal que separa os momentos da narração e da história. Na narrativa clássica (em terceira pessoa) a distância é geralmente indeterminada. Os efeitos de convergência final jogam com o fato de que a duração da história diminui progressivamente a distância que a separa do momento em que a narração é produzida. A história, assim, segue para reunir-se com a narração, porém é importante que a duração da narração não exceda a da história.

A narração ulterior apresenta o paradoxo de possuir simultaneamente uma situação temporal em relação à história contada e uma essência atemporal da narrativa. O mesmo não acontece na narração simultânea ou intercalada, já que se baseia na relação entre a sua própria duração 
e a da narrativa. Proust passou mais de dez anos escrevendo seu romance, mas o ato da narração de Marcell não traz marcas de duração, funcionando como se fosse instantâneo. $O$ presente do narrador, intercalado com vários momentos passados do herói, é um momento sem progressão, praticamente instantâneo.

Segundo a prática corrente da narrativa autobiográfica, a narrativa conduz o herói até o ponto em que o narrador o espera. “O narrador conduz precisamente a história do seu herói - até o ponto em que o herói vai se tornar narrador" (Jean Rousset). A distância temporal e espacial que separava a história do ato narrativo reduz-se progressivamente até ser reduzida a zero quando se une à narração.

\section{Níveis narrativos}

Todo acontecimento contado por uma narrativa encontra-se num nível diegético imediatamente superior àquele que se situa o ato narrativo que produz tal narrativa. $\mathrm{O}$ ato de escrever uma história fictícia é um ato literário - extradiegético, portanto. Os eventos narrados nessa história estão na primeira narrativa, sendo diégeticos, ou ainda, intradiegéticos. A instância narrativa de uma narrativa primeira é, por definição, extradiegética. Uma história contada dentro de uma outra história é chamada de narrativa segunda, e sua instância narrativa, metadiégetica. Narradores-autores, como M. de Renoncourt e Crusoé, estão no mesmo nível narrativo extradiegéticos que seu público (os leitores).

A narrativa no segundo grau é uma forma tradicional e diretamente ligada às origens da narração épica. Pode-se classificar três tipos principais de relação de união entre a narrativa metadiegética e a narrativa primeira: 
1 - Causalidade direta entre os acontecimentos da diegése e da metadiegése, que acaba por dar à narrativa segunda uma função de explicação. Essas narrativas respondem a uma pergunta: “Quais acontecimentos que conduziram à situação presente?”. Esse tipo de narrativa metadiegética é uma variante da analepse explicativa.

2 - O segundo tipo não evoca nenhuma relação de espaço ou tempo entre a diegése e metadiegése, que se ligam apenas por uma relação temática. Mesmo assim, essa relação temática, ao ser percebida, pode influenciar a situação diegética. A parábola e a fábula são gêneros que se baseiam na analogia.

3 - O terceiro tipo não liga a diegése e à metadiegése por nenhuma relação explícita entre os níveis da história. O próprio ato da narração desempenha uma função na diegése, não importando o conteúdo metadiegético. A função pode ser, por exemplo, de obstrução, como em “As Mil e Uma Noites”, em que Xerazade utiliza as histórias narradas para distrair o sultão.

Podemos notar que do primeiro ao terceiro tipo, a instância narrativa ganha cada vez mais importância. No primeiro a relação de encadeamento é direta, não passando pela narrativa; no segundo, a relação é rigorosamente mediatizada pela narrativa; no terceiro, por fim, a única relação que garante a passagem é o próprio ato narrativo.

\section{Metalepses}

O trânsito entre os níveis narrativos só pode acontecer mediante a própria narração, que por 
meio de um discurso introduz numa determinada situação o conhecimento de outra. Quaisquer outras formas de transição entre os níveis narrativos são impossíveis ou transgressivas. Cortázar, por exemplo, ao se dirigir ao leitor sugerindo que alguma atitude seja tomada, cria uma espécie de transgressão conhecida como metalepse do autor.

Segunda a definição de Gérard Genette, “toda intrusão do narrador ou do narratário (leitor) extradiegético no universo diegético (ou de personagens diegéticas num universo metadiegético)" são metalepses narrativas. Algumas transgressões são mais discretas e inocentes, mas há outras bem mais ousadas, em que, por exemplo, o narrador extradiegético obriga o personagem diegético a tomar esta ou aquela atitude.

As metalepses jogam com a transposição de limites criados por uma fronteira oscilante e sagrada - o mundo em que se conta e o mundo contado. O que há de mais perturbador na metalepse é a hipótese de que o extradiegético é talvez diegético: o narrador e seus narratários fazem parte de alguma narrativa.

Pessoa

Genette não emprega a terminologia primeira e terceira pessoa por considerar que, apesar de comuns, têm efeito inadequado ao colocar o acento da variação num elemento invariante da situação narrativa - a presença explícita ou implícita da pessoa do narrador que, como qualquer sujeito de enunciação em relação ao seu próprio enunciado, está na primeira pessoa. Supor que essa seja uma escolha meramente gramatical é um equivoco. O autor não faz uma escolha entre duas formas gramaticais, mas entre duas atitudes narrativas: contar a história por uma das suas personagens ou por um narrador alheio à história. A gramática é uma 
conseqüência quase mecânica. Se considerarmos que o narrador pode a qualquer instante intervir na narrativa, toda narração é feita em primeira pessoa. A questão é saber se o narrador pode ou não empregar a primeira pessoa para designar um de seus personagens. Sob esse aspecto, Genette classifica a narrativa em dois tipos: uma, em que o narrador é ausente da história que conta, e outra, em que é presente. O primeiro tipo será chamado de heterodiegético e o segundo homodiegético.

A ausência do narrador é absoluta, mas sua presença pode variar em graus. O tipo homodiegético é então subdividido em duas variantes - uma em que o narrador é o herói, e outra em que desempenha um papel secundário, como testemunha e observador. A primeira variante recebe o nome de autodiegético e representa o grau mais forte do homodiegético.

A relação entre narrador e história é, em princípio, invariável, porém esse limite foi ampliado pelo romance contemporâneo que permitiu que se estabelecesse entre narrador e personagens uma relação mais variável, flutuante.

Definido o estatuto do narrador pelo seu nível narrativo - extra ou intradiegético - e sua relação à história - hetero ou homodiegético -, teremos quatro tipos possíveis de estatutos:

Extradiegético-heterodiegético - exemplificado por Homero, narrador do primeiro nível, que conta uma história da qual está ausente.

Extradiegético-homodiegético - exemplificado por Gil Blas, narrador do primeiro nível que conta a sua própria história. 
Intradiegético-heterodiegético - exemplificado por Xerazade, narradora do segundo nível, que conta histórias das quais está, em geral, ausente.

Intradiegético-homodiegético - exemplificados por Ulisses, nos cantos IX a XII, narrador do segundo nível que conta sua própria história.

Uma das dificuldades da narrativa autobiográfica é o fato de que alguns eventos ultrapassam o campo dos conhecimentos do herói. Segundo Genette, surge uma situação paradoxal, uma narrativa "em primeira pessoa", mas, por vezes, onisciente.

O herói narrador

Atribuir a qualquer narrador outro papel que não seja o da narração pode causar estranhamento; entretanto, o discurso de um narrador pode assumir funções distintas.

A primeira dessas funções é a própria função narrativa - a história - e nenhum narrador pode fugir desta tarefa. O segundo aspecto está ligado ao texto narrativo, que organiza internamente o discurso - a função de regência (direção). O terceiro está ligado à situação narrativa, protagonizada pelo próprio narrador e o narratário, que pode ser presente, ausente ou virtual. A preocupação com o estabelecimento e manutenção de uma relação com os narratários faz com que os narradores muitas vezes se interessem mais para essa relação do que pela própria narrativa e voltem-se primordialmente ao seu público, privilegiando a função de comunicação.

Genette cita Jakobson ao mencionar a orientação do narrador para ele próprio, que designou 
ao narrador uma função emotiva ao tratar da parte tomada pelo narrador na história que conta. Além de afetiva, acrescenta Genette, essa função tem caráter moral e intelectual. Podendo assumir também uma função de testemunho, quando o narrador indica a fonte ou cita seus próprios conhecimentos. A função ideológica ${ }^{10}$ aparece em formas mais didáticas de comentários autorizados feitos pelo narrador. Evidentemente essas cinco funções não são puras, agindo sempre em conjunto com outras. Nenhuma - exceto a primeira (função de narrativa)-é completamente indispensável.

O narratário

Poderíamos atribuir ao papel do destinatário um caráter meramente passivo, limitado a receber a mensagem. Entretanto, assim como o narrador, o narratário protagoniza a situação narrativa, ocupando obrigatoriamente o mesmo nível diegético. Não devemos confundir o narrador com o autor e narratário com o leitor. Uma narrativa realizada por um narrador intradiegético, por exemplo, destina-se a um narratário igualmente intradiegético. Os leitores jamais poderiam se identificar com esses narratários, já que sua presença é sequer suposta por esses narradores mergulhados na lógica da história contada. Tal recurso permite a manutenção de uma certa distância entre os leitores reais e o narrador.

Ao contrario, o narrador extradiegético só pode visar um narratário extradiegético - uma espécie de leitor virtual com quem qualquer leitor poderia identificar-se. Este narrador fora da diegése poderia até fingir não se dirigir a ninguém, mas toda narrativa - como todo discurso é necessariamente dirigida a alguém.

\footnotetext{
${ }^{10}$ Comentários ideológicos não são monopólios do narrador. Alguns personagens recebem de seus autores a tarefa do comentário e do discurso didático.
} 
A obra proustiana se vale de um intenso recurso ao leitor, atribuindo a ele funções de adivinhações e interpretações. Segundo o próprio Proust, a obra é um instrumento de ótica que o autor oferece ao leitor, para o ajudar a ler em si. "Cada leitor é, quando lê, leitor de si próprio".

Genette conclui "O Discurso da Narrativa" dizendo que "o verdadeiro autor da narrativa não só é quem a conta, mas também, e por vezes muito mais, quem a escuta. E que não é necessariamente aquele a quem é dirigida - há sempre gente ao lado.”

A voz do jogo

Talvez a instância narrativa de um jogo esteja na criação da jogabilidade, ao definir como o narratário vai interferir ou não no desenrolar da narrativa. Genette lembra que as determinações temporais na literatura são sempre mais relevantes do que as espaciais, porém em geral não é o que acontece nos jogos, que acabam sempre privilegiando as determinações espaciais. O tempo de um jogo é sempre imediato ao da narrativa simultânea. "Full Throttle" inicia a narração de sua história no presente, remetendo a um tempo passado onde a história aconteceu; porém essa narrativa ulterior procede apenas até o momento em que o narrador desaparece e a história passa a acontecer no presente, diante de nossos olhos, até que finalmente somos "convidados" a participar da trama orientando as ações do herói. A infinita maioria dos jogos, ao simular uma realidade, abre mão de outra temporalidade que não seja a simultânea. Ao criar uma rigorosa coincidência entre o tempo da narração e o da história, esse recurso possibilita a transparência narrativa, possibilitando as simulações de realidade próprias dos jogos. Mesmo os jogos que brincam com o tempo apenas fazem isso nas seqüências não-interativas, e ao chegarem nos momentos de interação, tratam o tempo como 
presente simultâneo. Como algo que aconteceu no passado poderia ser passível de interação? As ações estão no passado e um jogo eletrônico exige que seu usuário controle ações. Acredito que a pista para uma nova possibilidade temporal nos jogos esteja na grande ação que se faz obrigatória ao abordar algo que ocorreu anteriormente - o ato de lembrar; o jogador, numa narrativa interativa ulterior, não deveria fazer o que o herói fez, mas apenas lembrar, ou até mesmo descobrir. "Riven" (seqüência de "Myst"), de certa forma, faz exatamente isso - o herói deve descobrir as ações que fizeram o mundo em que ele está preso, deve se transformar. Para isso o jogador deve ler uma série de diários de vários personagens, aproximando-se de uma narrativa ulterior. Mesmo assim "Riven” não é um jogo de narração ulterior, pois a ação não deixa de acontecer no presente, apenas remete-se ao passado.

Não podemos dizer que nos jogos as determinações espaciais sejam alguma vez irrelevantes, conforme é dito em relação a literatura. O espaço num jogo é quase sempre indispensável para que sua história proceda. As determinações espaciais dos jogos estão em geral relacionadas à focalização da narrativa, pois é através da definição desse ponto de vista que enxergaremos o espaço em que vamos imergir - da mesma forma que a focalização na literatura acaba por influenciar na maneira como experimentamos a temporalidade.

\section{Niveis narrativos}

"Full Throttle" é narrado pelo próprio herói, narrador intradiegético então. Será? Apesar de a narrativa ser iniciada por uma locução do próprio protagonista num tempo futuro, o restante da narração me parece apenas ser feito em focalização no herói, mas já não narrada por ele. A narração de "Full Throttle", como na maioria dos jogos, é quase transparente, camuflada na realidade artificial que proporciona a imersão do jogador. Em geral é essa transparência que 
faz com que o interador esqueça por alguns instantes que aquele não é o seu mundo. Mesmo escondido, como qualquer narrativa, todo jogo que conta uma história tem obrigatoriamente um narrador. Esse narrador se revela em vários momentos: no modo de controle, na interface, na trilha sonora, no visual e em todos os desafios que o jogador deve superar. No caso de “Throttle” apenas parte da primeira seqüência inicial é narrada pelo herói; a partir daí a narração muda e passa a escolher os eventos que o narratário deve conhecer (independente do fato de Ben conhece-los ou não) para tentar desvendar os enigmas propostos pelo jogo. Mas Ben não é de fato o narrador da história, há uma outra narração por trás, onde Ben está inserido.

Enquanto fala-se em narrador-herói na literatura, em jogos poderíamos usar o termo “narratário-herói”. A identificação entre o receptor da narração e seu protagonista não encontra meio mais propício do que os jogos. Essa presença do narratário em maior evidência do que na literatura - ou mesmo no cinema -, aliada a uma constante transparência do narrador, aponta-nos que o modo mais indicado para descobrir o nível narrativo estabelecido por um jogo é procurando a relação entre o narratário e a história. Podemos descobrir o nivel em que se encontra o narrador, descobrindo o nível em que se encontrao narratário, ja que narrador e narratário estão, obrigatóriamente, sempre no mesmo nível narrativo ${ }^{11}$.

Um jogo como "Doom”, focalizado internamente no protagonista, usa o recurso da transparência de narrativa às últimas conseqüências. Fazendo com que, além do narrador, o herói também se dilua, mas nesse caso fundindo-se com o narratário e compartilhando suas ações. Desse modo podemos dizer que se trata de uma narração intradiegética, já que o narratário faz parte do universo diegético junto com um personagem que protagoniza os

\footnotetext{
${ }^{11}$ A relação entre os comandos e interações e o nível narrativo poderia criar uma nova análise na forma como a interação é feita em qualquer obra narrativa interativa, possibilitando uma nova classificação dos níveis de interação baseados na
} 
acontecimentos da história. Em "Full Thottle" o narratário não está na diegése acompanhando a história a partir de outro nível narrativo; isso é perceptível não só pela focalização externa, mas também por todos os mecanismos que itermedeiam o controle e acompanhamento da história. Se em "Doom” o controle do personagem é feito da forma mais direta possível, simulando a presença do jogador na cena, “Thotlle”, como a maioria dos "adventures", usa uma série de interfaces para que o jogador possa interagir. A forma como o jogador comanda o herói também nos dá pistas de sua posição exterior à diegése - todos os comandos são espécies de sugestões, podendo o herói acatá-las ou não. Não se pode atribuir à focalização a definição de uma narração extra ou intradiegética. Os jogos de ação são exemplos que dissipam esse equívoco. Apesar de o jogador controlar o personagem a partir de um ponto de vista externo, a resposta aos comandos é imediata, voltando herói e narratário a se fundir, agindo diretamente nos acontecimentos de dentro da história, narração intradiegética, portanto.

A relação do narrador com a história, que determinaria a homodiegése ou a heterodiegése, não poderia ser medida pela posição do narratário. Desta vez é somente através do narrador que poderíamos definir essa característica de seu estatuto.

\section{Metalepses}

Sendo o jogador extradiegético em "Full Throttle", a comunicação entre personagem e narratário é uma transgressão, conforme relata Genette em seu livro. Os comentários feitos pelo herói aos comandos do jogador são metalepses usadas como recursos do humor que pontua o jogo. Dependendo da nossa sugestão de comando Ben responde: "Só por que você 
quer!", “Eu não vou pôr meus lábios nisso!" e assim por diante. O preço desses comentários é o prejuízo da imersão, que é automaticamente quebrada, e a cada momento somos lembrados de que não estamos vivendo aquela realidade. Mas em "Full Throtle" as transgressões no estatuto de narração fazem parte da própria concepção do jogo, que acaba por criar uma reflexão sobre o controle jogador/personagem quando quebra o silêncio freqüente entre essas instâncias. De um certo modo, até a intervenção do jogador no universo do herói pode ser considerada uma metalepse, pois o narratário comanda o jogo a partir de um outro nível narrativo.

\subsection{REFLEXÕES DO ENCONTRO}

Curiosamente a conclusão de "O Discurso da Narrativa", ao tratar do narratário, faz muitas alusões que elevam o leitor à proximidade com o jogador. Ao falar das funções que o leitor recebe na obra proustiana, Genette quase o caracteriza como um jogador de um jogo "adventure", que precisa adivinhar e interpretar informações. Tal confirmação me aponta que escolhi o caminho certo ao buscar na narrativa literária susídios para compreender os jogos. Em muitos aspectos a transposição de conceitos foi direta, em outros algumas adaptações foram necessárias, e em alguns requerem uma nova conceituação. Percebi, ao fazer este comparativo, que ainda há muita limitação narrativa, mesmo nos mais competentes jogos que contam histórias.

Daqui para frente pretendo, na minha pesquisa, pôr em prática alguns recursos narrativos raramente usados nos jogos. Acredito que em muito me distanciarei do conceito de jogo que convencionalmente encontramos no mercado, mas é através dessa experiência que pretendo apontar novos caminhos. 


\section{CAPÍTULO 2}

\section{LIMBO - DOCUMENTO DE PRODUÇÃO DO JOGO (GAME DESIGN)}

\subsection{VISÃO GERAL}

LIMBO é um jogo de suspense em que o jogador controla um espírito desencarnado em busca de respostas que revelem quem foi o responsável por sua morte. O espírito terá habilidades crescentes que permitirão que a exploração seja cada vez mais eficiente assim o protagonista passará de testemunha imperceptível a personagem com poderes para alterar o rumo da história.

\subsection{SINOPSE}

Luiz Grandier, um homem de 38 anos, de hábitos incomuns e suposto praticante de magia negra vivia num prédio de três andares e cinco apartamentos. Durante uma tempestade o prédio ficou sem energia elétrica, impedindo qualquer pessoa de entrar ou sair. Luiz Grandier foi assassinado nessa noite e seu espírito passou a vagar pelos apartamentos em busca de respostas que expliquem sua morte. 


\subsection{DESCRIÇÃO DOS PERSONAGENS}

\section{O protagonista}

Luiz Grandier - Aos 38 anos de idade aparentava ser bem mais velho; era calvo e grisalho.

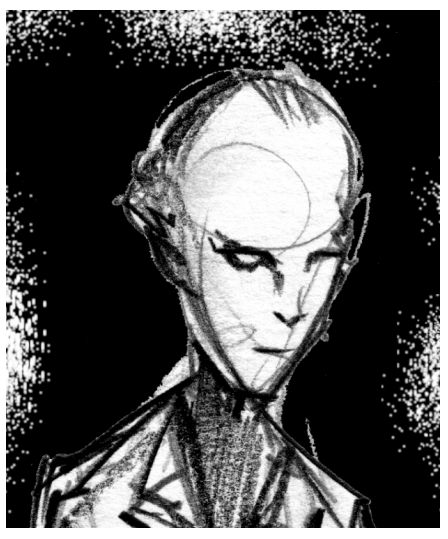

Por ser alto e ter má postura desenvolveu uma corcunda que completava seu visual funesto. Grandier era muito reservado, não tinha amigos e não saía com freqüência; era solitário e pouco se sabe sobre sua família. Deixou os pais aos 11 anos, quando decidiu abandonar sua cidade natal, no interior de Goiás; viveu nas ruas de Goiânia até ser adotado por um senhor, que passou a ser seu mentor. Quando Luiz completou 20 anos, seu pai adotivo faleceu e ele deixou Goiânia em direção a São Paulo, em busca de um velho amigo do pai. Por dezesseis anos viveu com Aníbal McFadden, que se transformou em seu mestre nas ciências ocultas. Grandier passou a trabalhar como vendedor na livraria que pertencia a McFadden. Após o recente desaparecimento de seu mestre, Luiz passou a cuidar da loja como se fosse sua.

\section{O mentor}

Aníbal McFadden - Velho, magro e bastante sisudo, raramente ria; porém, havia um certo tom de humor dúbio na maioria de seus comentários e muito rude ao se comunicar. Introvertido, o único contato que mantinha com outras pessoas era através da sua loja, que ficava no primeiro andar do prédio onde morava com Grandier. Aníbal não se interessava por

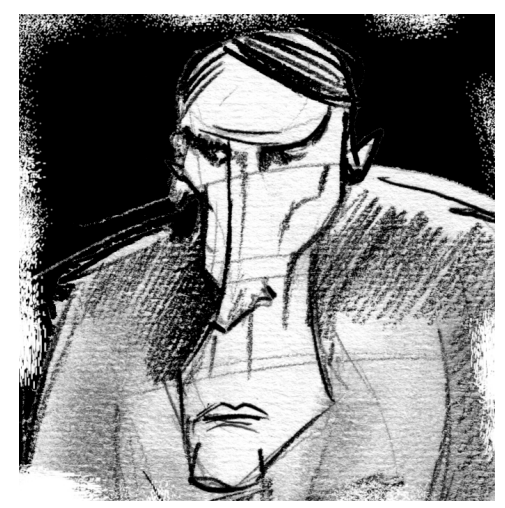


ninguém, por isso achava que não deveria perder seus preciosos segundos com "exemplares da estupidez humana", como ele costumava se referir aos outros. Difícil determinar a idade de McFadden; era um daqueles senhores que evitam mostrar traços de velhice. Apesar de ter pouco cabelo, não era calvo e penteava para trás os fios compridos, secos e tingidos de preto. Ao contrário de Luiz, Aníbal era muito vaidoso, física e sobremaneira intelectualmente, pois adorava ser elogiado por seus conhecimentos. Aníbal desapareceu sem deixar rastro; não se sabe se ele está morto, mas por dois anos não se tem notícia dele.

\section{Os vizinhos}

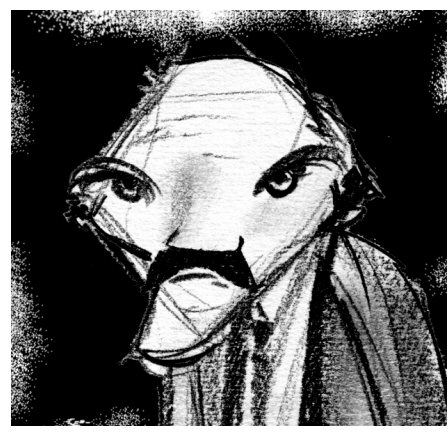

Edson Guariglia - Morador do sexto andar, num apartamento duplo que divide com sua esposa, Marília de Paula Guariglia. Trabalha como contador, tem 52 anos e estatura mediana, é barrigudo e careca, e usa um volumoso bigode. Um homem grosseiro, que fala e ri alto enquanto espalha fumaça de cigarro.

Edson jamais se pergunta se poderia estar incomodando alguém; é bastante encrenqueiro e, não obstante, freqüentemente sente-se ofendido por seus vizinhos. Síndico do condomínio, reclama e briga com todos os moradores do edifício. O relacionamento com sua esposa é bem atribulado - freqüentemente Edson a espanca durante acaloradas discussões causadas geralmente por Marília, que tenta mudar o comportamento de seu marido. Com exceção do senhor Yan, do primeiro andar, Guariglia não se relaciona bem com nenhum de seus vizinhos - especialmente Grandier, que se tornou amigo de sua esposa. 


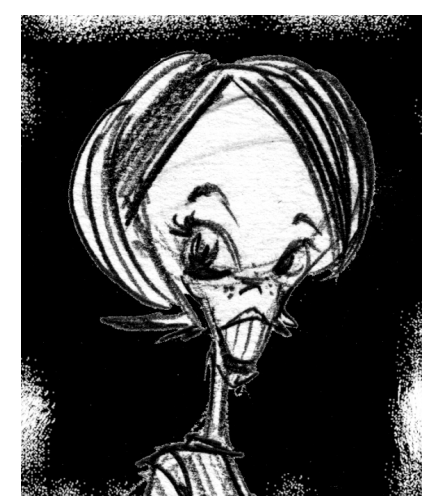

Marília de Paula Guariglia - Dona de casa, 45 anos; apesar de romântica, é resignada com o fato de estar casada há 20 anos com o grosseiro Edson. Muito vaidosa, Marília está sempre bem vestida, mesmo que o compromisso seja apenas uma ida à feira na esquina mais próxima. Marília é muito simpática e tem bom relacionamento com todos os vizinhos; aliás, é por respeito a ela que os moradores não respondem à altura às provocações de Edson. Marília gosta muito de Luiz Grandier; no início suas conversas eram breves e corriqueiras, mas com o tempo os dois passaram a ter uma relação mais próxima e Grandier passou a ser seu confidente.

Edwin Souza - Jovem tímido de 26 anos, vizinho de frente de Grandier. Edwin é estudante de teologia e trabalha numa igreja evangélica no centro da cidade como principal assistente do pastor. Muito religioso, é uma pessoa extremamente rígida, tanto no modo como se veste quanto em suas atitudes. Por causa disso julga qualquer comportamento que não se enquadre em suas crenças, ficando muito

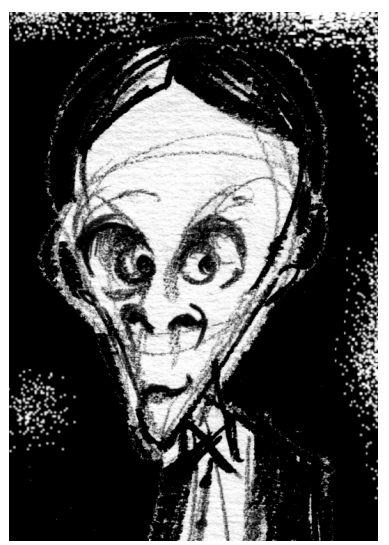
mal-humorado ao presenciar qualquer ato que julgue ofensivo a sua religiosidade. Edwin não se relaciona com muitas pessoas fora de sua comunidade evangélica; aliás, evita contato com quaisquer pessoas fora do círculo de sua igreja, a não ser que Edwin imagine que possa convertê-las. Após descobrir que Grandier é um praticante de magia, Edwin passa a agredi-lo verbalmente e a rezar em voz alta cada vez que o encontra pelo prédio. 


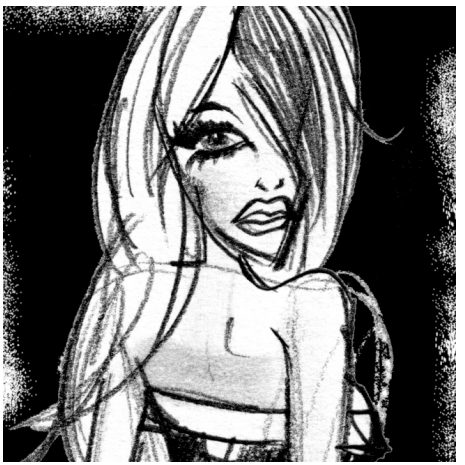

Alexia Oliveira - Uma loira de 23 anos, bonita, voluptuosa e muito sensual. Alexia é uma luxuosa garota de programa, vive no edifício há pouco tempo, mas rapidamente se transformou num dos principais assuntos da vizinhança. Alexia se veste de maneira provocante e alia a isso um comportamento nada

discreto. Ela faz questão de provocar todos os homens que cruzam seu caminho, como se fosse um hobby ou uma espécie de treinamento. Grandier ficou muito interessado na nova moradora. Até descobrir que ela era uma garota de programa a assediou inúmeras vezes, mas depois da descoberta acabou virando um cliente bem assíduo. A relação dos dois ficou muito forte, Alexia acabou se envolvendo com Grandier, que mesmo assim não deixou de ser seu cliente, o que deixou seu namorado, Alan que a visitava constantemente, muito enciumado.

Alan Marinho - Apesar de não morar no edifício, Alan é um visitante assíduo. Tem 34 anos, é musculoso, tatuado nos braços e tem o cabelo raspado. Namora com Alexia e age como se fosse seu protetor. Na verdade Alan é muito mais um aproveitador do que outra coisa; não tem emprego fixo, faz pequenos serviços e quando não está envolvido com algum trabalho muda-se para a

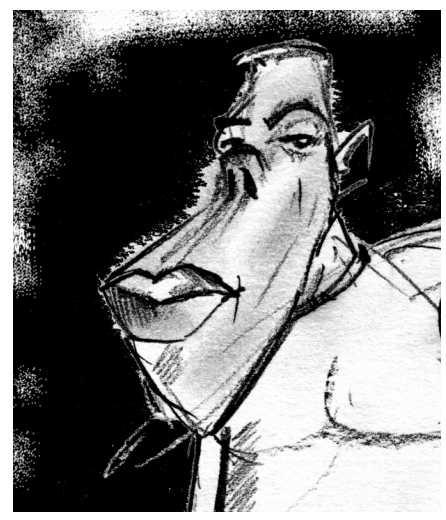
casa da namorada. Alan é muito agressivo, física e verbalmente.

Yan Sudslowsky - Yan é o morador mais antigo do prédio, um senhor de 78 anos, cabelos brancos, escassos e penteados para trás. Yan é muito ágil e ativo para sua idade, vive só e não precisa da ajuda de ninguém. Relaciona-se muito pouco com os vizinhos, é extremamente reservado e raramente sai de seu apartamento. Yan também é envolvido com as ciências 
ocultas. Era amigo de McFadden, mas a amizade foi perdida por divergências em relação ao uso dos supostos poderes adquiridos com os rituais. Yan é um homem muito ressentido, amargurado e seu passado é misterioso, provavelmente pelo que aconteceu entre ele e Aníbal McFadden, mas ninguém mais sabe o motivo do

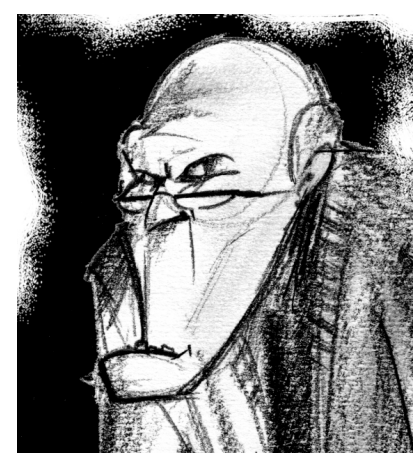
desentendimento dos dois. Yan Sudslowsky não confia no comportamento de Grandier por acreditar que é um mal discípulo de McFadden.

\subsection{DESCRIÇÃO DO MUNDO}

Todos esses personagens vivem num prédio antigo próximo à região central da cidade de São Paulo. A data dos acontecimentos retratados no jogo não é determinada, mas é por volta do final da década de 90. Esse edifício tem três andares e o térreo, onde fica a livraria de Aníbal McFadden.

O mundo em que esses personagens vivem e interagem, num primeiro momento, segue a lógica do mundo real, mantendo as leis físicas naturalistas que experimentamos na realidade.

Os acontecimentos que extrapolam o realismo estão nos eventos ligados à morte do protagonista. Após o assassinato de Grandier seu espírito passa a recordar os rituais e encontros com McFadden, e, ao lembrar das práticas e ensinamentos do passado, o espírito ganha gradualmente novas habilidades: passa a vagar livremente pelo prédio, interage com objetos inanimados, desvincula-se da ação temporal e materializa-se por um curto espaço de tempo. Os demais personagens reagirão a esses eventos de diferentes maneiras, mas com o espanto - o que é esperado, mantendo-se a lógica realista num universo em que eventos como 
esses não são normais.

As habilidades não-naturais que o espírito de Luiz Grandier obtém são frutos de sua relação em vida com as ciências ocultas. Tais habilidades só passam a ter efeito quando o espírito consegue lembrar-se de cada um dos ensinamentos e torná-los conscientes. Lembrar é um acontecimento ativo; só a partir da busca por essas memórias é que o conhecimento adquirido em vida servirá ao espírito. O ato de lembrar, no presente, é que fará com que o aprendizado no passado passe a ser útil. O espírito de Grandier se recorda de quando, ainda em vida, havia sido iniciado em magia e essas lembranças funcionam como uma ponte entre esses dois momentos, permitindo uma espécie de retorno feito pelo espírito ao momento das aulas.

Porém, o uso dessas habilidades, por não ser algo natural na lógica do mundo onde se passa o jogo, faz com que o espírito perca a energia consciente responsável pela sua existência. O uso excessivo desses artifícios ou a permanência prolongada no mundo dos vivos consome essa energia consciente até que o espírito deixe de existir. O único modo de recarregar essa energia é voltando para o corpo no centro da sala.

\subsection{DESCRIÇÃO GERAL DO FUNCIONAMENTO DO JOGO}

Apesar de continuar classificando esse projeto como jogo, pretendo "esvaziar" as características de competição e disputa típicas dos "games", valorizando os elementos narrativos e privilegiando a história. Porém, pretendo manter outros conceitos presentes em qualquer jogo eletrônico: fases, objetivos definidos, missões, obstáculos e recompensas. Esses 
elementos lúdicos serão ferramentas para que a história seja contada a partir dos comandos e escolhas do jogador.

Dependendo da forma como o jogador conduzir o protagonista a história a ser contada se transforma dentro de linhas pré-definidas. O jogador, porém, não irá decidir o que acontece com os personagens, mas optar por caminhos e ações que o levarão a desenlaces distintos. Se, por exemplo, o jogador optar por investigar a história focalizando um personagem em especial, o final será obrigatoriamente ligado a esse personagem.

A interação com a história acontece de duas formas: procurando as memórias do protagonista em uma tela com vários ícones móveis que nos permitem acessar às cenas (não-interativas), que são exibidas a partir de suas escolhas, e controlando o espírito desencarnado do protagonista que "vaga" por todo o prédio em que acabou de ser assassinado. A cada fase o espírito terá novas habilidades, fazendo com que deixe de ser uma simples testemunha das ações dos vizinhos até interagir com o ambiente e com os personagens e interferir no desenrolar da história.

A estrutura do jogo é formada por fases em que o jogador controla o personagem - "fases de controle", intercaladas por fases em que o jogador escolhe as memórias a que quer assistir "fases filmes".

As fases em que o jogador controla o espírito, as "fases de controle", serão ambientes tridimensionais navegáveis por onde o espírito terá livre movimentação. Se o espírito testemunhar um diálogo entre dois personagens poderá andar ao redor deles durante a conversa, escolhendo o ponto de vista mais apropriado. $\mathrm{O}$ jogador pode controlar o espírito 
por um ambiente em que ações simultâneas estão acontecendo, escolhendo qual delas ele prefere observar.

As fases em que o jogador escolhe e assiste às memórias do protagonista são as "fases filmes". Cada uma dessas fases inicia-se com uma interface em que vários ícones que representam momentos distintos da vida de Grandier estão escondidos na tela, e com o uso do mouse o jogador clica nos ícones que encontrar, desencadeando a exibição de seqüências audiovisuais que mostram partes da vida do protagonista. Essas seqüências são filmes comuns e durante a exibição não há interação.

Esses dois momentos do jogo são inter-relacionados - cada um deles influencia diretamente o outro. Durante as "fases filmes" o jogador pode assistir apenas a algumas memórias, mas dependendo das memórias escolhidas a narrativa toma uma direção diferente, transformando o enredo e encaminhando a história através de acontecimentos distintos. As memórias apresentadas, por sua vez, dependem da ação do espírito durante sua perambulação pelo prédio nas "fases de controle". Os personagens e objetos que forem encontrados pelo espírito durante esse tipo de fase, desencadeiam memórias ligadas a eles, que serão acionadas e apresentadas no próximo momento em que o protagonista recordar momentos da sua vida.

Algumas dessas memórias apresentadas nas "fases filmes" serão fundamentais para que o protagonista adquira habilidades necessárias para a continuação do jogo. Enquanto essas seqüências-chave não forem acessadas o jogo não volta para a "fase de controle". Da mesma forma, enquanto o protagonista está sendo controlado pelo jogador, algumas ações são chaves, e apenas quando todas essas ações forem realizadas é que a fase terá fim. 
A história muda determinada pelas opções do jogador. Se, por exemplo, as memórias e os cômodos visitados relacionados a um personagem específico forem maioria nas escolhas do jogador, a narrativa seguirá um caminho que leve a acontecimentos e ao desfecho ligado àquele personagem sem que o jogador determine o que acontecerá no final.

\subsection{MECÂNICA DO JOGO}

\subsubsection{OBJETIVOS E REGRAS}

O jogador deve procurar elementos que componham a trama navegando através da narrativa de duas formas distintas: assistindo às memórias do protagonista, nas "fases filmes" ou visitando os apartamentos dos vizinhos, controlando o fantasma do protagonista, nas "fases de controle". O jogo será composto por oito fases - quatro "fases filmes" intercaladas com quatro "fases de controle".

\section{"Fases filmes"}

As “fases filmes" oferecem seqüências audiovisuais não-interativas que mostram memórias dos eventos que aconteceram antes da morte do protagonista. Cada uma dessas cenas fornece dados a respeito da vida de Luiz Grandier. Usando o mouse, clicando em pontos móveis da tela, o jogador procura e escolhe memórias que acionam cenas. Cada ícone escondido aciona um filme respectivo, com uma cena da vida de Luiz Grandier. O objetivo é encontrar uma memória em particular (a seqüencia-chave) para que o jogo progrida e siga para a próxima "fase de controle". Essas seqüencias-chave mostrarão encontros entre Luiz Grandier e seu mentor, Aníbal McFadden. 
As “fases filmes" só terão fim depois que esse tipo de memória tiver sido acessada; porém, o número de memórias acessadas não poderá ser menor do que três. Por isso, mesmo que a seqüência-chave tenha sido descoberta na primeira tentativa, o jogador deve encontrar ainda mais duas memórias e assistir às respectivas cenas. $\mathrm{Na}$ "fase de controle" seguinte o personagem volta com um novo poder aprendido na seqüência-chave exibida.

\section{"Fases de controle"}

Usando o teclado e o mouse o jogador controla o espírito de Luiz Grandier por um ambiente tridimensional com todos os cômodos do prédio. A cada "fase de controle" o espírito adquire novas habilidades a partir das seqüencias-chave assistidas durante as "fases filme".

Na primeira "fase de controle" o espírito apenas se locomove pelo prédio, presenciando diálogos entre seus vizinhos. Na segunda "fase de controle" o fantasma já consegue interferir no ambiente e pode mover certos objetos de cada apartamento, procurando reações elucidativas dos vizinhos. Na terceira "fase de controle" o espírito volta no tempo e vê as ações dos suspeitos antes do momento do assassinato. Na quarta e última "fase de controle" o fantasma volta no tempo novamente, mas desta vez pode se materializar e tentar impedir o crime.

A simples permanência no mundo dos vivos consome a energia consciente do espírito. Toda vez que o personagem utilizar as habilidades mágicas sua energia sofrerá uma grande perda. Isso impossibilita o jogador de utilizar os poderes em demasia, o que o leva a fazê-lo de modo estrategicamente planejado. A limitação de energia também fará com que o jogador não possa visitar todos os apartamentos em determinadas fases. A energia só pode ser carregada nas 
proximidades do cadáver e para que o espírito não deixe de existir, terminando a partida, o jogador deve reconduzi-lo até o local do crime.

\subsubsection{SISTEMA DE PONTUAÇÃO}

Determinação do desenlace da trama

As escolhas das memórias nas "fases filmes" e das visitas aos apartamentos vizinhos nas "fases de controle" definem o final da história.

Há seis finais possíveis e cada memória ou visita fornece pontos que vão encaminhar o jogo para o final respectivo. O final relacionado ao personagem com maior pontuação será o escolhido. O jogador não tem acesso a esses valores e nem ao sistema de escolha dos finais. A pontuação segue o sistema abaixo:

- As memórias fornecem pontuação completa (2 pontos) ou parcial (1 ponto). Uma mesma memória pode fornecer pontos para mais de um final.

- As visitas também fornecem pontuação com a mesma lógica: pontuação completa (4 pontos) e parciais (2 pontos). Assim como as memórias, uma única visita pode fornecer pontuação a mais de um final.

\subsubsection{DESCRIÇÃO DE INTERFACE}

O jogo mistura a focalização interna, na qual vemos através dos olhos do personagem, e a 
focalização externa, que mostra o personagem em cena. Em geral os momentos nãointerativos, formados por seqüências audiovisuais que contam a história serão apresentados com a focalização externa, enquanto os momentos interativos trarão a visão para os olhos do personagem, com a focalização interna.

As "fases filmes" apresentarão seqüências audiovisuais comuns, fornecendo informações a respeito da vida pregressa do protagonista. Cada uma dessas seqüências poderá ser escolhida pelo jogador através de uma interface que mostrará uma tela escura repleta de ícones vagando aleatoriamente, representando as respectivas seqüências. Os ícones não ficam aparentes sem que o jogador os encontre passando o cursor sobre áreas móveis espalhadas pela tela. Ao serem encontradas, essas áreas mostrarão o ícone e, com um clique no mouse, serão ativadas e irão direcionar o jogo para a exibição da seqüência relacionada. As cenas audiovisuais serão formadas por animações bidimensionais visualizadas em tomadas fixas.

Durante as "fases de controle" o jogador visualiza o ambiente tridimensional navegável através dos olhos do personagem controlado (o espírito de Grandier). Esse espaço pode ser explorado pelo jogador através de comandos no teclado e no mouse.

Todo o tipo de informação necessária será indicada utilizando-se elementos dentro da estrutura diegética em que o personagem está inserido. Por isso a interface será "transparente" - não há informações visuais extra-diegéticas, como barras de energia, pontuação, radares e mapas. As informações oferecidas ao jogador serão apenas:

a) quantidade de energia consciente;

b) habilidades ativas (que podem ser utilizadas a cada uma das fases). 
Essas informações visuais serão disponibilizadas na palma da mão do corpo espiritual, na forma de uma tatuagem iluminada que só será visível quando o jogador ativar essa interface, fazendo que o espírito olhe para a palma da mão.

\subsubsection{DESCRIÇÃO DE COMANDOS}

O jogador controla as ações do fantasma da seguinte forma:

\subsubsection{CONTROLE DE MOVIMENTAÇÃO}

- setas do teclado ou teclas “ $W$ ”, “ $A$ ”, " $S$ ” $e$ " $D$ ”: indicam a movimentação do espírito; "W” faz o personagem se mover para frente, "A" para esquerda, "D” para a direita e "S" para trás.

\subsubsection{CONTROLE VISUAL}

- movimentação do mouse: a movimentação do mouse controla o olhar do espírito, permitindo ao jogador explorar visualmente cada cenário, sem que isso afete a movimentação do personagem;

- clique com botão esquerdo do mouse: analisa o objeto clicado; se for algo pertinente ao andamento da história, o espírito fará um comentário que colabore para a compreensão da trama; se não, um comentário padrão será executado; no caso das memórias ou objetos muito próximos aos olhos do protagonista, o simples clique já acionará a ação; 
• "T": o personagem olha para a tatuagem na palma de sua mão e tem acesso às informações de energia e habilidades ativas; o brilho da tatuagem indica a quantidade de energia, e um símbolo no polegar a habilidade que pode ser usada naquela fase.

\subsubsection{CONTROLE DE HABILIDADES AVANÇADAS}

Para que os poderes aprendidos em vida sejam acionados o espírito de Grandier deverá executar um pequeno ritual. Esse ritual ensinado nas exibições das cenas de memória deve ser controlado pelo jogador, que deve invocar esses poderes ativamente, usando os botões certos e as palavras "mágicas" que devem ser digitadas através do teclado. Apenas depois da execução desse procedimento as teclas funcionarão. Esses rituais funcionarão como códigos que deverão ser acionados, via teclado, apos a ativação desta função, ao apertar a tecla "X".

\section{Interferência em objetos ou personagens}

(ativa a partir da segunda "fase de controle")

- Tecla de espaço: faz o personagem interagir com o objeto / personagem que estiver a sua frente.

- "E": empurra objetos*.

- "P": puxa objetos*.

- "F": faz as pessoas próximas ao espírito sentirem calafrios*.

\section{Outros controles avançados}

- "C": faz o espírito parar, concentrar-se e recuperar a energia consumida; esse comando só pode ser ativado próximo ao cadáver de Grandier. 
- "V": volta no tempo* (apenas na terceira e quarta "fases de controle").

- "M": materializa o espírito* (apenas na quarta "fase de controle").

*Habilidades adquiridas pela prática da magia negra, com alto consumo de energia.

\subsection{ARGUMENTO}

Numa noite de tempestade um raio provoca falta de energia no edifício "Plaza Acali 330", na região central de São Paulo, um prédio de três andares onde moram sete pessoas. A porta elétrica do prédio trava, impedindo a entrada ou saída de qualquer um. O início da história é marcado por dois fortes trovões, seguidos por uma sirene de ambulância que passa nas proximidades do prédio, um trovão mais fraco e, por fim, um disparo. Durante a escuridão Luiz Grandier foi assassinado com um tiro nas costas. Grandier agoniza, perturbado por não saber quem o matou, não consegue morrer em paz e passa a se lembrar de vários momentos de sua vida.

Nesse momento inicia-se a participação do jogador, na primeira "fase filme" do jogo. A interface apresenta ícones animados vagando na tela; cada um desses objetos clicáveis dará acesso a cenas que mostram as memórias do protagonista. Uma dessas lembranças mostra um encontro com seu mestre, Aníbal McFadden, que havia lhe passado ensinamentos ligados ao ocultismo e à magia (essa é a primeira seqüência-chave audiovisual; só após sua exibição o jogo continua).

Durante todas as "fases filmes" as memórias das aulas com o mentor serão sempre seqüências-chave e farão os ensinamentos voltarem à consciência espiritual de Grandier, 
dando-lhe "poderes" pós-vida. O espírito passa a ter novas habilidades a partir da próxima "fase de controle". A primeira nova habilidade faz seu espírito adquirir consciência e permanecer num mundo que já não é seu lugar: o mundo dos vivos.

Deixando a primeira "fase filme" o jogo passa a uma nova forma de interação na "fase de controle". Agora o jogador comanda o espírito de Grandier, que passa a vagar livremente pelo prédio à procura de respostas que expliquem seu assassinato. Enxergando pelos olhos do espírito o jogador pode visitar todos os apartamentos do prédio e observar cada morador instantes após sua morte. Apesar da liberdade de controle, ao se distanciar do corpo o espírito perde energia; se essa energia chegar ao fim o espírito desaparece e o jogo acaba. A energia só pode ser recarregada no local do crime, nas proximidades do cadáver. Ouvindo os comentários dos vizinhos, todos pareciam ter motivos para odiar Grandier; nada fica esclarecido com as visitas.

Através dos eventos assistidos pelo espírito, seguindo as escolhas do jogador, o final da trama será definido. Sempre que os eventos assistidos pelo protagonista, entre memórias e visitas aos apartamentos, privilegiarem um determinado personagem, a trama será orientada numa direção que aponte um desfecho ligado a esse mesmo personagem.

Quando o espírito retorna ao local do crime o jogo segue numa nova "fase filme", que traz novas lembranças com informações que revelam o relacionamento de Grandier com os moradores do prédio. A seqüencia-chave mostra um novo ensinamento: Grandier passa a poder interferir sutilmente em determinados objetos inanimados de cada ambiente do prédio. 
Com essa nova habilidade adquirida o espírito de Grandier volta a vagar pelo prédio em uma nova "fase de controle". Porém, a partir desse momento o número de opções será limitado: o jogador poderá visitar apenas um número pré-definido de apartamentos.

O jogador poderá visitar até dois apartamentos e interferir nos objetos. Cada morador reage a esses estímulos de uma maneira:

- Yan, o velho do primeiro andar, ri e não se importa com nenhum movimento sobrenatural de qualquer objeto, apesar de entender a causa do fenômeno;

- Marília fica amedrontada e entende que aquilo é algum tipo de alerta ou sinal, e Edson, seu marido, a ridiculariza e atribui os movimentos ao vento;

- Edwin, o jovem evangélico, fica transtornado e passa a rezar repetidamente;

- Alexia e Alan reagem com apatia a qualquer estímulo, mas um objeto em especial cai no chão deixando Alan constrangido - um molho de chaves estava sobre seu criado mudo e Alexia percebe que ele esconde alguma coisa.

Depois das duas visitas aos apartamentos o espírito é obrigado a voltar para o local do crime, pois sua energia fica muito baixa. Ao se aproximar do corpo o jogo volta à interface em que as lembranças são escolhidas numa nova "fase filme". Munido das conclusões que tirou das reações dos suspeitos Grandier escolhe as lembranças ligadas a cada vizinho. Dentre as memórias escolhidas, a seqüencia-chave com o mentor mostra que Grandier havia aprendido que o tempo é um elemento do mundo dos vivos e um espírito desencarnado está livre das limitações temporais, já que sua existência segue uma outra lógica. Isso permite que Luiz Grandier tenha acesso ao passado recente e investigue a ação de cada morador nos instantes que precederam seu assassinato. 
Uma seqüência de filme mostra o espírito de Grandier rodando no centro do local do crime; ao fundo os acontecimentos acontecem de trás para frente, o espírito pára bruscamente e um flash interrompe a seqüência audiovisual. O jogo volta para a "fase de controle"; o espírito de Grandier voltou no tempo e pode explorar o prédio instantes antes do seu assassinato. $\mathrm{O}$ jogador pode determinar o tempo até o momento da morte de Grandier orientando-se pelos sons que marcaram seus últimos momentos de vida: os dois trovões fortes, a sirene, o trovão fraco e, se o jogador não conseguir interferir, o disparo final indicando que o assassinato aconteceu.

Nesta fase, o jogador poderá visitar apenas um apartamento. As ações de cada vizinho nos instantes que precederam o disparo:

Apartamento 1 - $\mathrm{O}$ velho Yan procura alguma coisa nas prateleiras de sua biblioteca. Ao achar um livro grosso sem título e quase destruído, Yan o retira com cuidado e leva-o para a mesa central. Sudslowsky senta-se, abre o livro e encontra algumas folhas avulsas escritas à mão: são cartas deixadas por McFadden. Yan as lê até descobrir algo que o deixa assustado. Ele fecha o livro, mantendo as cartas ali, e sai do apartamento pela porta da cozinha.

Apartamento 2 - Alan está ao celular tentando falar com Alexia, que não está no apartamento, mas está no prédio. A campainha toca, Alan corre até a porta e encontra Edson, que lhe entrega um molho de chaves. "Você sabe o que fazer", diz o marido traído antes de virar as costas e sumir na escuridão. Alan volta para o celular e, como não consegue encontrar sua namorada, irrita-se e joga o aparelho no chão, veste o casaco e sai do apartamento em direção à escada de emergência. 
Apartamento 3 - Edwin rezava na sala de sua casa até que um raio tirou sua concentração. Assustado, o jovem vai até a parede que faz divisa com o apartamento de Grandier e, por uma rachadura no canto, Edwin observa seu vizinho em algum ritual pagão. Com ódio o jovem vai até uma cômoda da sala, pega um pacote e sai da sala.

Apartamento 5 - Ao mesmo tempo Edson e Marília estão tendo uma discussão; o marido acusa sua esposa de traição e ela chora bastante. Edson sai do quarto batendo a porta, deixando a mulher às lágrimas; Marília vê um caderno de capa rosa - é o diário de Alexia. Marília lê um relato sobre os momentos de sexo que a garota teve com Grandier, o que a deixa muito nervosa. Levanta-se decidida, guardando o diário na bolsa e saindo do quarto.

Depois de testemunhar as ações do vizinho escolhido o espírito de Grandier volta ao momento presente numa cena não-interativa que o mostra perturbado - nenhuma informação parece ter sido conclusiva.

Uma nova "fase filme" oferece mais memórias que mostram os momentos climáticos do relacionamento de Grandier com cada um dos vizinhos. O jogo só prossegue após o acesso da seqüência-chave do encontro com MacFadden, em que Grandier aprendeu que a materialização de um espírito é possível por alguns instantes. Porém essa nova habilidade consome a energia consciente responsável pela existência; se algo o machucar enquanto seu espírito estiver materializado ou se esse estado não-natural for demasiadamente prolongado, os danos no espírito serão permanentes.

Mais uma vez o espírito de Grandier volta no tempo. Uma nova seqüência audiovisual 
focaliza o espírito rodando no centro da sala enquanto, ao fundo, os acontecimentos são mostrados de trás para frente.

O jogo passa para a última "fase de controle", em que o jogador pode vagar pelo prédio e fazer o espírito se materializar. Durante a materialização o espírito de Luiz Grandier passa a ter algumas limitações de percepção e de locomoção. A tela por onde o jogador enxerga os ambientes explorados será borrada e escura.

Dependendo das lembranças e cenas a que o jogador tiver assistido nas fases anteriores, a história seguirá por diferentes caminhos, levando a diferentes desfechos, com os seguintes finais possíveis:

$1-$ McFadden assassino

- Grandier foi o responsável pelo desaparecimento de seu antigo mestre; depois que aprendeu tudo que considerava necessário, Grandier matou McFadden e o incinerou na fornalha do porão da livraria, onde os rituais com animais eram feitos.

O espírito materializado caminha na direção do quarto e vê Grandier ajoelhado, meditando; nas costas dele um outro espírito se materializa - MacFadden, que levanta o braço apontando uma arma para a nuca de Grandier. O espírito de Grandier tenta impedi-lo, mas Yan Sudslowsky aparece e o segura, dizendo "Agora é a sua vez... depois da sua morte, você procurou o passado... Aníbal se ocupou do futuro...". O disparo é simultâneo ao corte que finaliza a história. 
- O espírito de Grandier se materializa enquanto Grandier meditava ajoelhado no centro da sala. Enquanto vê sua última meditação, ouve um barulho no quarto; ele corre para dentro e vê Alexia caída ao lado da cama, nua, com desenhos no corpo. Ela acorda, se assusta com os desenhos em sua pele e levanta-se com dificuldade. O espírito se esconde na sombra do guarda-roupa. Alexia vê sobre o criado-mudo um livro com gravuras que está aberto numa página e nota que uma outra foi arrancada. A ilustração mostra uma mulher com uma faca cravada no coração e abaixo se lê "Rito de Sacrifício do Amor". Assustada, abre a gaveta e encontra um revólver embrulhado num pano sujo. O espírito pula tentando impedi-la, mas o desenho no corpo da garota brilha, criando um escudo de luz que deixa o espírito sem sentidos. Alexia corre para a sala, aproxima-se de Grandier e hesita; os dois trovões ressoam; Grandier permanece em transe; a ambulância passa; um novo trovão assusta a garota; ela puxa o gatilho. Alexia vê ao lado do corpo a gravura arrancada do livro; é uma garota com desenhos como os que ela tem no corpo e envolta num círculo de luz; abaixo se lê "Rito de Proteção do Amor". Ela chora, pega a ilustração e sai do apartamento correndo. O espírito vê toda a cena e se desmaterializa.

\section{3 - Alan e Edson assassinos}

- O espírito se materializa no quarto, ao lado do criado-mudo, onde encontra a arma embrulhada num pano sujo. O espectro pega o revólver, deixa o quarto e vai para a sala, onde sua versão viva está em transe. Os dois trovões quebram o silêncio; em seguida um som vindo da lavanderia, da porta que dá acesso à escada de incêndio, chama a atenção do espírito. Ele corre para os fundos e vê Alan entrando na casa. Alan vê o espírito materializado e imagina tratar-se do próprio Grandier. A ambulância passa. O espírito levanta a arma apontando para Alan, que se assusta: "Não, não é isso, a gente só queria assustar você... abaixa isso, por favor...". O trovão mais forte antecipa o som de tiro, que não vem da arma de Grandier. Alan 
volta para a escada de incêndio assustado, enquanto o espírito corre para a sala e encontra seu cadáver caído na frente de Edson, que segura uma arma com o cano fumegante. Edson olha para o espírito: "Maldita escuridão, hein, Alan? Vamos embora...". O espírito se desmaterializa, Edson vai em direção à lavanderia e deixa o apartamento de Grandier.

\section{$4-$ Edwin assassino}

- O espírito se materializa no corredor de entrada do apartamento de Grandier e caminha enquanto sua visão fica mais clara. Na sala encontra seu corpo vivo meditando, em transe. $\mathrm{O}$ espírito vai até o quarto e pega a arma escondida no criado-mudo ao lado da cama e volta para a sala em que meditava. Os dois primeiros trovões rompem o silêncio, a porta do apartamento se abre e o espírito esconde-se atrás do sofá. Edwin entra cautelosamente no apartamento e aproxima-se de Grandier, que permanece imóvel no centro da sala. Edwin começa a orar repetidamente. Isso perturba o espírito, que deixa de ouvir qualquer coisa além da voz do evangélico repetindo frases bíblicas como mantras. O espírito começa a se desmaterializar; para ele já não há mais dúvida - Edwin é o assassino. O espírito pula na direção do rapaz, Edwin interrompe a reza e se espanta com um outro Grandier na sala: “O que é isso?... Está amarrado! Em nome de Jesus! Deus me protege dos demônios que você invoca... em nome de Jesus! Está amarrado!!! Em nome...”. O som da sirene de ambulância se junta à oração de Edwin. Grandier começa a se desmaterializar e o revólver cai no chão, ao mesmo tempo em que o terceiro trovão ressoa. Edwin pega a arma e dispara em Grandier. Tudo fica escuro ao som do tiro.

\section{5 - Marília assassina}

- O espírito se materializa no último andar; ainda lá ele ouve o primeiro trovão; desce correndo para seu apartamento, cuja porta já está aberta, entra e vê seu corpo vivo ainda em 
posição de meditação. Um barulho vem da cozinha; o fantasma vai até quarto à procura da arma, mas só encontra o pano. Olhando pela fresta da porta do quarto ele encontra Marília, que está com um copo de whisky nas mãos e tremendo muito. Do apartamento superior podese ouvir Edson gritando, pedindo para que a mulher abra a porta. Ela chora e cai sentada: "Eu não sei por que coloquei você nessa situação... você é mais do que um amigo...”. Em vão Marília tenta acordar Grandier: "Luiz, fala comigo!". Edson volta a gritar. Ela olha para cima e diz: "Eu não posso colocar meu marido em risco". Ela se levanta, pega a arma da bolsa e atira na nuca de Luiz Grandier. Tudo fica escuro, enquanto o choro da mulher se distancia lentamente.

\section{$6-$ Espírito assassino}

- O espírito se materializa no quarto e movimenta-se com dificuldade; a visão é embaçada e escura; na gaveta do criado-mudo ele pega um revolver enrolado num pano sujo e entra na sala. Um vulto pula em sua direção, o que cria duas subdivisões desse final:

a) o espírito de Grandier atinge o próprio Grandier ainda vivo; o assassino foi seu próprio espírito perturbado;

b) o vulto se aproxima e agarra o espírito materializado; o vulto é Luiz Grandier, que percebe que está diante dele mesmo; assustado, Grandier larga o espírito, que se desmaterializa; Grandier senta-se e fica perturbado com o que aconteceu; os dois trovões, a ambulância e o trovão fraco passam, mas dessa vez não há disparo; a energia elétrica volta ao prédio.

\section{"Vencendo o jogo"}

Durante os finais o jogador controla o protagonista materializado; com exceção do sexto final, ele pode impedir sua morte se conseguir atingir o seu assassino antes do disparo fatal. Se isso 
acontecer em qualquer um dos finais de 1 a 5 o espírito desaparece e Grandier desperta assustado de seu estado meditativo e, ao olhar ao redor, vê um corpo (do assassino do respectivo final exibido), a arma ao lado e, imaginando que em seu transe cometeu um assassinato, livra-se do corpo no incinerador da livraria.

\subsection{DESCRIÇÃO PROGRESSIVA FASE A FASE}

\section{Introdução - vinheta audiovisual não-interativa}

Durante uma forte tempestade um raio atinge o prédio deixando a porta trancada por falta de energia. Dois relâmpagos antecedem a passagem de uma ambulância. Outro trovão e em seguida um disparo. Um corpo está no centro da sala do apartamento. Foi atingido na nuca. É Luiz Grandier, que não consegue morrer em paz e passa a recordar momentos sua vida.

Fase Filme 01 - memórias da infância de Grandier

- Aos 9 Anos, no supermercado com o pai.

- Aos 10 anos, flagrando a mãe agredida.

- Aos 11 anos, presenciando uma briga entre os pais e fugindo de casa.

- Aos 12 anos, vivendo na rua e encontrando o pai adotivo.

- Aos 14 anos, recebendo aulas de seu pai adotivo.

- Aos 16 anos, conhecendo Anibal McFadden, amigo de seu pai adotivo.

- Aos 17 anos, presenciando uma discussão entre seu pai adotivo e McFadden.

- Aos 19 anos, morte de seu pai adotivo. Convite para mudar-se para o apartamento de McFadden.

- Aos 19 anos, mudança para o apartamento de McFadden. 
- Aos 20 anos, recebendo uma aula de magia em que aprende o controle da consciência (seqüência-chave).

Vinheta audiovisual não-interativa

O espírito de Grandier se desprende do corpo caído no chão. O fantasma olha o ambiente ao redor e percebe que pode explorar o prédio.

\section{Fase de Controle 01}

Fantasma visita os vizinhos logo após a morte

- Apartamento 01 - Yan entra no apartamento e procura livros de magia.

- Apartamento 02 - Alexia entra no apartamento e procura por Alan que aparece do lado de fora da lavanderia.

- Apartamento 03 - Edwin está assustado, andando pelo apartamento.

- Apartamento 04 - Marília chega à sala chorando; Edson a encontra vindo da área de serviço; eles brigam.

\section{Vinheta audiovisual não-interativa}

No apartamento de Grandier o fantasma retorna ao corpo.

\section{Fase Filme 02}

Memórias de Grandier no prédio

- Yan e Edson conversam no hall de entrada. Ao encontrar Grandier perguntam sobre o paradeiro de McFadden.

- Grandier na livraria observa Alexia saindo do prédio e a assedia.

- Durante uma conversa Grandier aborda o passado de McFadden que, irritado, não responde.

- Marília deixa o apartamento de Luiz Grandier, agradecendo sua atenção. O vizinho de frente Edwin vê e a repreende. 
- Edwin bate na porta de Grandier pedindo para que ele abaixe o som.

- Edson procura McFadden na livraria, a mulher entra logo atrás e troca sorrisos com Grandier.

- Alexia finge procurar um livro, Grandier a ajuda e flerta com a garota. Alan se aproxima e, violentamente, tira a garota de lá.

- Grandier visita o velho Yan, que lhe conta que era praticante de magia ao lado de McFadden.

- Marilia recebe Grandier na sala de seu apartamento. Ela confessa suas frustrações com o marido. Edson chega e se irrita com a presença de Grandier, que tenta se explicar.

- McFadden ensina Grandier a expandir seu campo consciente e a mover objetos (seqüência-chave).

\section{Vinheta audiovisual não-interativa}

O fantasma se desprende do corpo morto e movimenta os objetos da sala.

\section{Fase de Controle 02}

Fantasma visita os vizinhos e move objetos

- Apartamento 01 - Yan está à escrivaninha, lendo. O espirito move livros e apaga velas, mas o velho não se assusta.

- Apartamento 02 - Alexia está ouvindo música e Alan anda irrequieto. O espírito move vasos e porta-retratos, assustando apenas a garota. Quando derruba um molho de chaves, faz a garota ficar intrigada com Alan.

- Apartamento 03 - Edwin está sentado na poltrona da sala. O fantasma move quadros, apaga velas e abre a Bíblia, fazendo Edwin começar a rezar.

- Apartamento 04 - Marília está no quarto e Edson fuma na varanda. O espírito derruba a aliança, quebra o espelho e estoura a luz do abajur. Marilia fica amedrontada, Edson tenta acalmá-la. 


\section{Vinheta audiovisual não-interativa}

No apartamento de Grandier o fantasma se movimenta com dificuldade. Sem energia, retorna ao corpo, sendo absorvido pelas narinas.

\section{Fase Filme 03}

Memórias de Grandier no prédio

- Marilia beija Grandier à porta do apartamento dele.

- À procura de Alexia, Alan bate violentamente na porta do apartamento de Grandier.

- Antes de sair para trabalhar Alexia toma uma bebida com Grandier, contando sobre sua relação conturbada com o namorado.

- Grandier encontra um cofre na livraria, tenta abri-lo usando diversas combinações; McFadden entra na livraria, deixando-o sem ação.

- Edson vai ao apartamento de Grandier à procura de McFadden e encontra um brinco da esposa.

- Grandier folheia vários livros à procura de alguma coisa. McFadden se irrita com o comportamento do aprendiz.

- Edwin invade o apartamento de Grandier buscando algo nos livros. Grandier chega e Edwin foge assustado.

- Yan e Grandier conversam sobre o pai adotivo. Eles discutem.

- Alexia e Grandier estão em seu apartamento; vão se beijar quando Alan interrompe ao bater na porta.

- Grandier lê no diário de seu mestre um relato em que McFadden descreve Grandier.

- McFadden ensina Grandier que a cronologia dos espíritos é livre (seqüência-chave).

\section{Vinheta audiovisual não-interativa}

O espírito se descola do corpo e começa a girar rapidamente; ao fundo cenas de trás para frente aparecem. O espírito pára de rodar bruscamente e vê, no centro da sala, Grandier ainda vivo. meditando. 


\section{Fase de Controle 03}

Fantasma volta no tempo e visita os vizinhos

- Apartamento 01 - Yan pega um livro muito antigo e encontra cartas de McFadden; ao ler, o velho fica assustado e deixa o apartamento.

- Apartamento 02 - Alan tenta falar com Alexia pelo celular, Edson toca a campainha e lhe entrega um molho de chaves. Alan deixa o apartamento pela escada externa.

- Apartamento 03 - Edwin está rezando quando um raio tira sua concentração. Por uma fenda na parede ele vê Grandier meditando. Edwin deixa o apartamento.

- Apartamento 04 - Edson e Marília discutem. Edson deixa o apartamento acusando a mulher de traição. Marília se levanta e também sai do quarto.

\section{Vinheta audiovisual não-interativa}

O fantasma olha com atenção; um "flash" interrompe a cena; a câmera focaliza o cadáver no apartamento.

\section{Fase Filme 04}

Memórias de Grandier no prédio

- Alexia chega ao prédio machucada, Grandier vê a garota e a convida para seu apartamento. Ela aceita e os dois fazem sexo.

- Marília se desculpa com Grandier. A mulher suspeita que o marido está envolvido no sumiço de Aníbal McFadden.

- Grandier está meditando no centro da sala quando Edwin invade o apartamento e o interrompe com orações.

- Grandier está conversando com Yan quando Edwin entra e pede para Grandier conhecer o pastor de sua igreja. Edwin olha para o porão e Grandier fecha a porta. Yan percebe que Grandier esconde alguma coisa ali.

- Grandier descobre um código na contracapa de um livro de magia.

- Sem ser notado Grandier escuta uma conversa entre Edson e Alan a respeito de supostas barras de ouro de McFadden.

- Marília vai à livraria e puxa conversa com Grandier. Edson interrompe e é violento ao 
tirar a mulher da loja.

- Yan pede a Grandier que deixe o prédio, alertando que aquele não é seu lugar.

- Alexia e Grandier estão na cama; a garota se levanta, Grandier aponta para uma cômoda com dinheiro. Sem pegar nada ela simplesmente vai embora, despedindo-se com um beijo.

- Grandier lê no diário de seu mestre um relato em que McFadden descreve Grandier.

- McFadden ensina Grandier a materializar o espírito (seqüência-chave).

\section{Vinheta audiovisual não-interativa}

O espírito se descola do corpo e deixa o apartamento. No saguão de entrada volta a girar rapidamente; ao fundo mais cenas de trás para a frente aparecem. O espírito pára de rodar bruscamente, aparecendo na escadaria durante a tempestade.

\section{Fase de Controle 04}

Fantasma volta no tempo, materializa-se e tenta impedir o assassinato. - Finais Possíveis

- Luiz Grandier matou seu mestre. McFadden viajou no tempo para o futuro e se materializou para vingar-se.

- Alexia acorda no quarto de Grandier, que medita na sala. A garota se assusta com desenhos em seu corpo, acreditando que Grandier pretende sacrificá-la num ritual.

- Edson e Alan invadem o apartamento de Grandier para assassiná-lo e roubar o suposto ouro de McFadden.

- Edwin, convencido de que seu vizinho é um bruxo demoníaco, decide matar Grandier.

- Com medo que Luiz Grandier prejudique seu marido, Marília vai ao apartamento dele decidida a eliminá-lo.

- O espírito de Grandier volta no tempo; ao encontrar um vulto que se movimenta em sua direção imagina tratar-se do assassino, mas é ele mesmo momentos antes do assassinato. 


\subsection{DESCRIÇÃO DO ESPAÇO NAVEGÁVEL (“LEVEL” DESIGN)}

Todas as "fases de controle" acontecem num mesmo ambiente - o edifício em que morava

Luiz Grandier. Ao controlar o fantasma o jogador poderá acessar todos os cômodos do prédio: cinco apartamentos, uma loja de livros, o hall de entrada e as escadas.

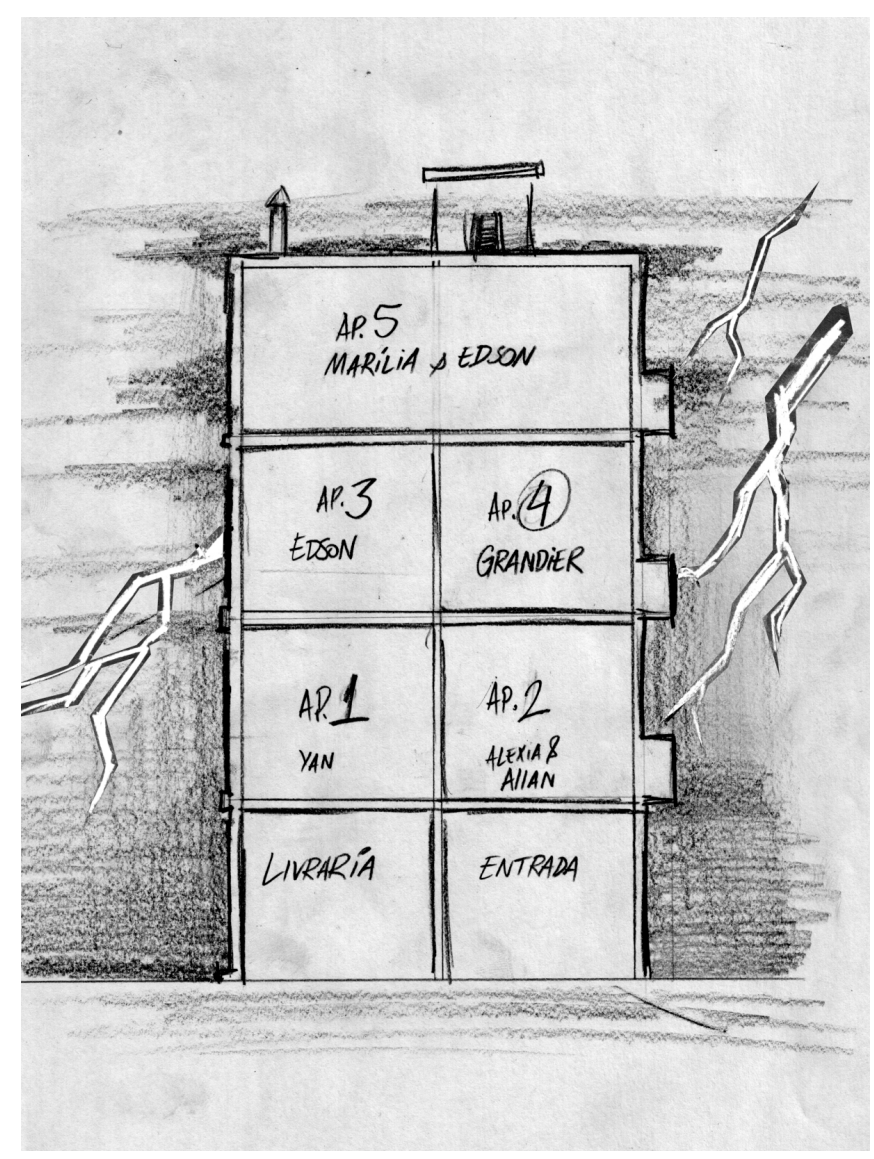

figura 1. Corte mostrando a distribuição de apartamentos e moradores

$\mathrm{O} 1^{\circ}$ e o $3^{\circ}$ apartamentos têm uma planta igual; o $2^{\circ}$ e o $4^{\circ}$ apartamentos têm a planta espelhada do $1^{\circ}$ e do $3^{\circ}$. O $5^{\circ}$ apartamento é duplo e sua área é formada pela fusão das duas plantas originais. Os três lances de escadas são iguais. A livraria tem uma planta própria, assim como o hall de entrada.

As ilustrações a seguir são plantas que mostram a distribuição espacial de cada andar do jogo. 


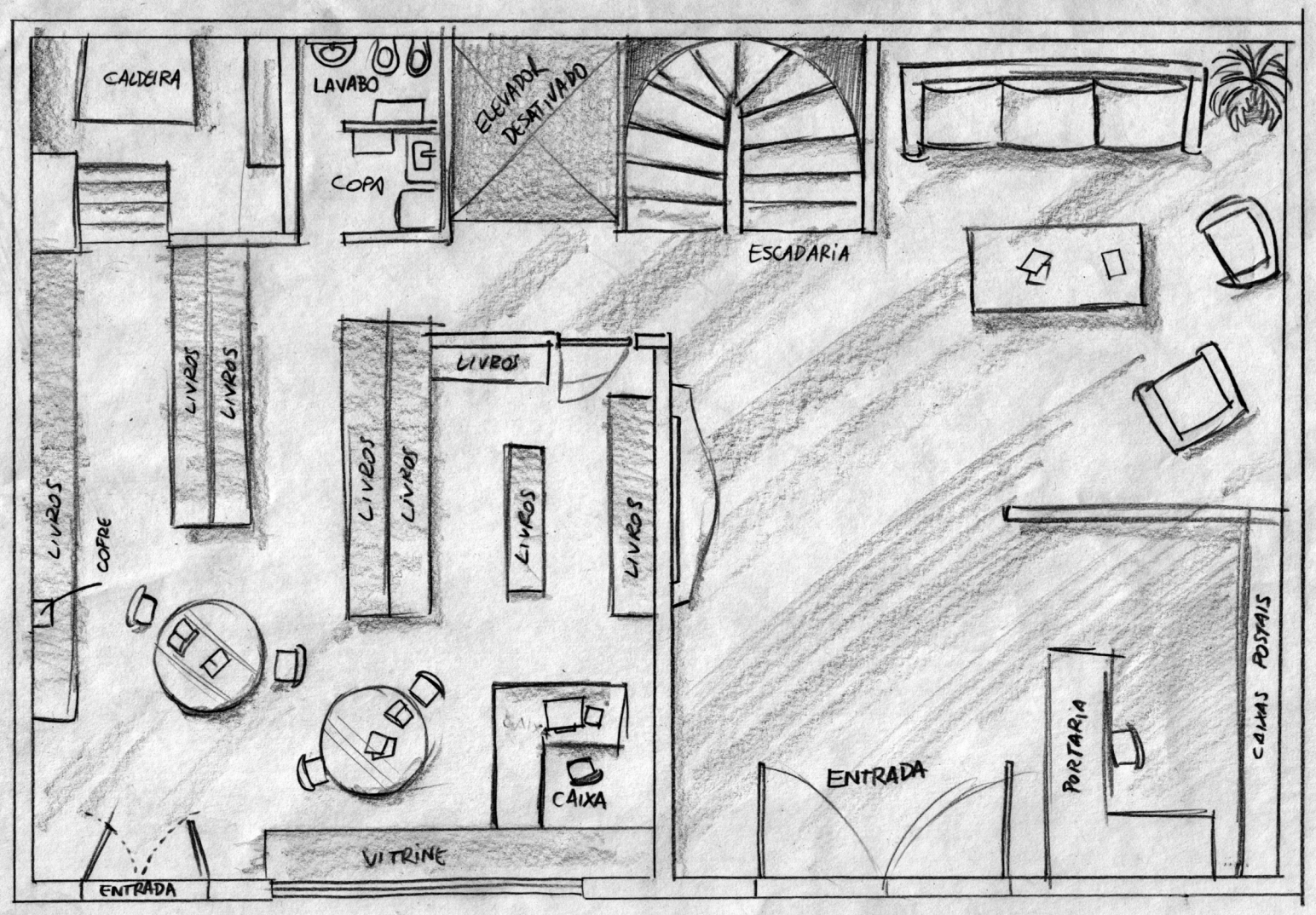

figura 2. Planta térreo

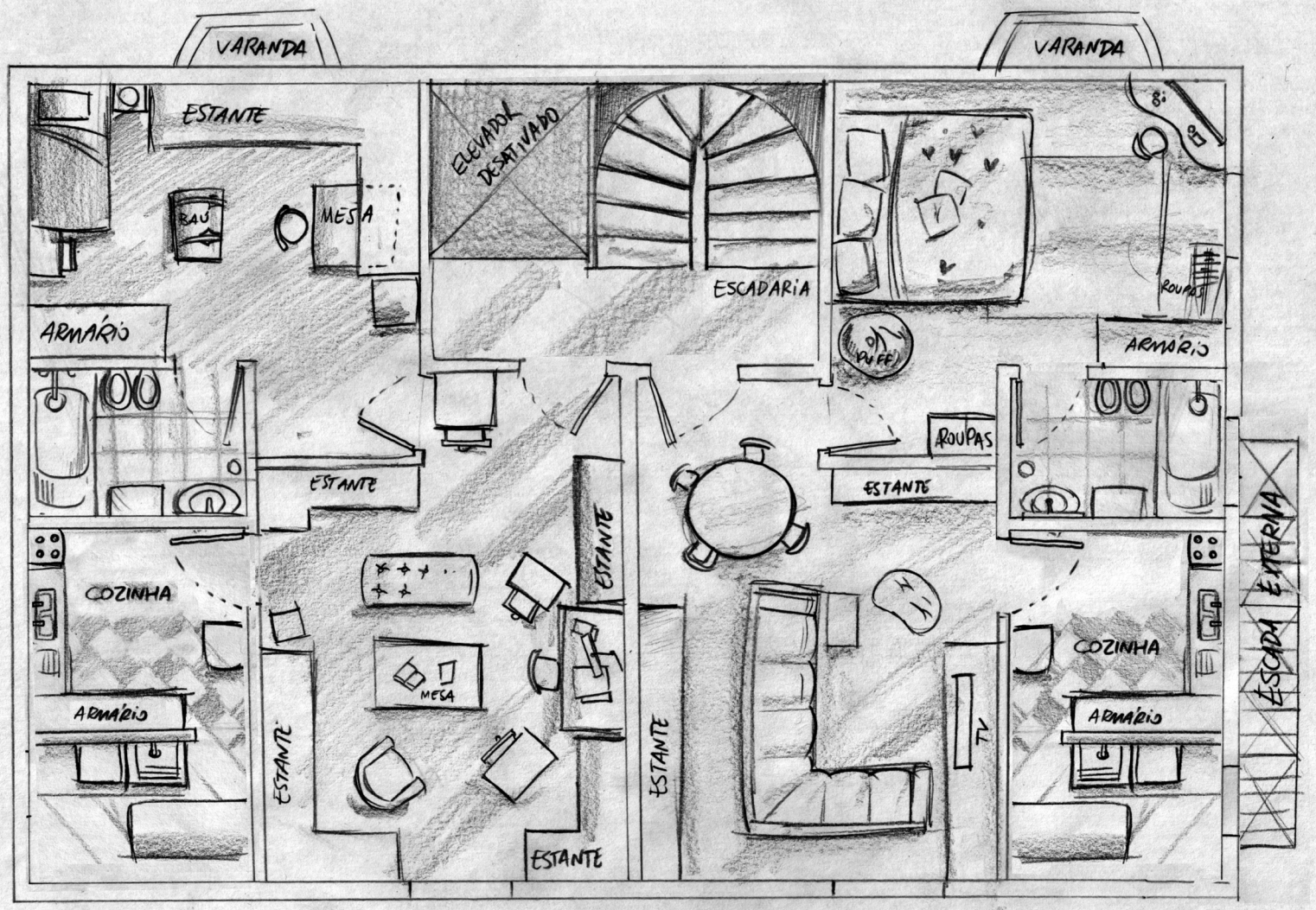

figura 3. Planta $1^{\circ}$ andar, apartamentos 1 e 2 


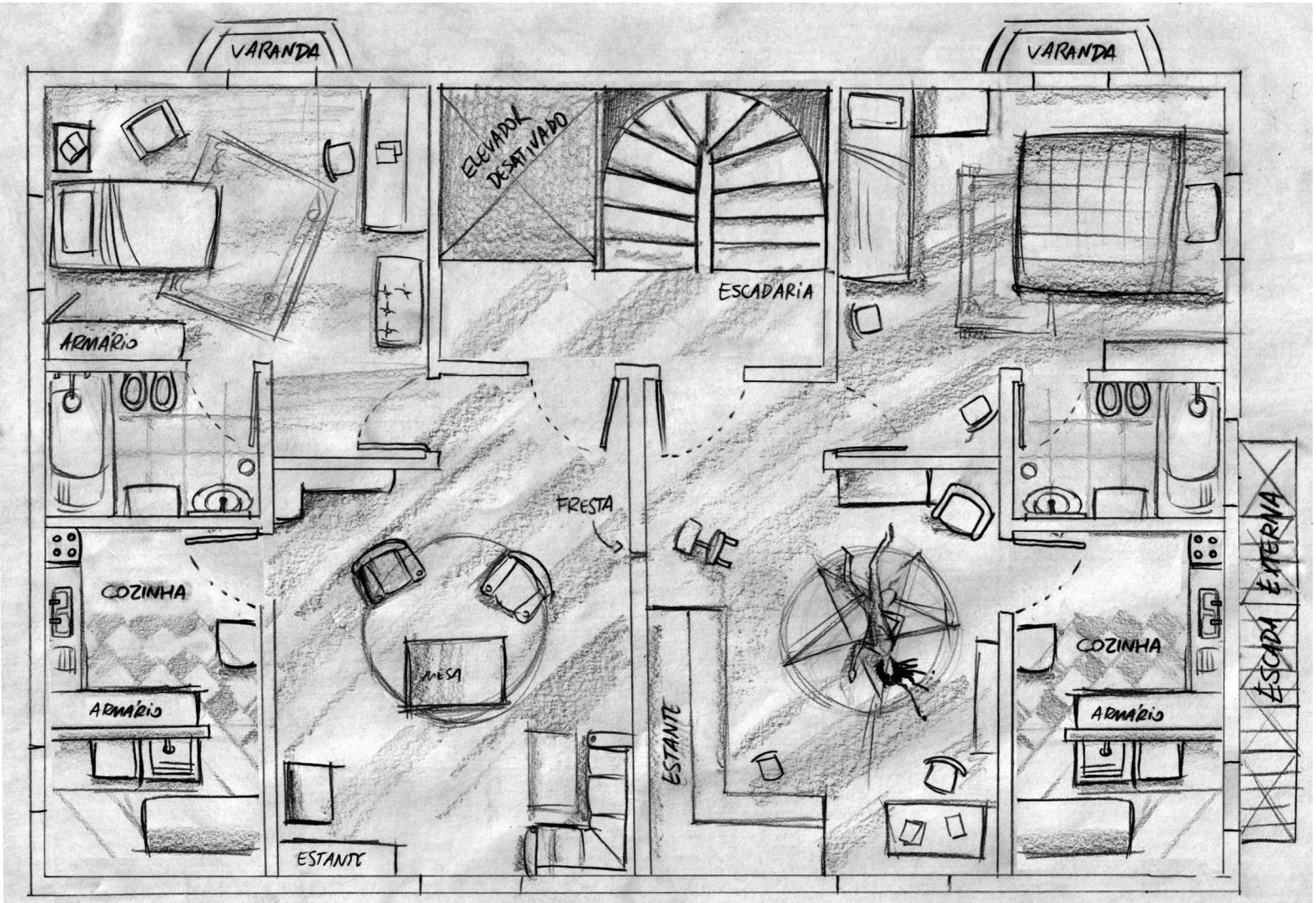

figura 4. Planta $2^{\circ}$ andar, apartamentos 3 e 4

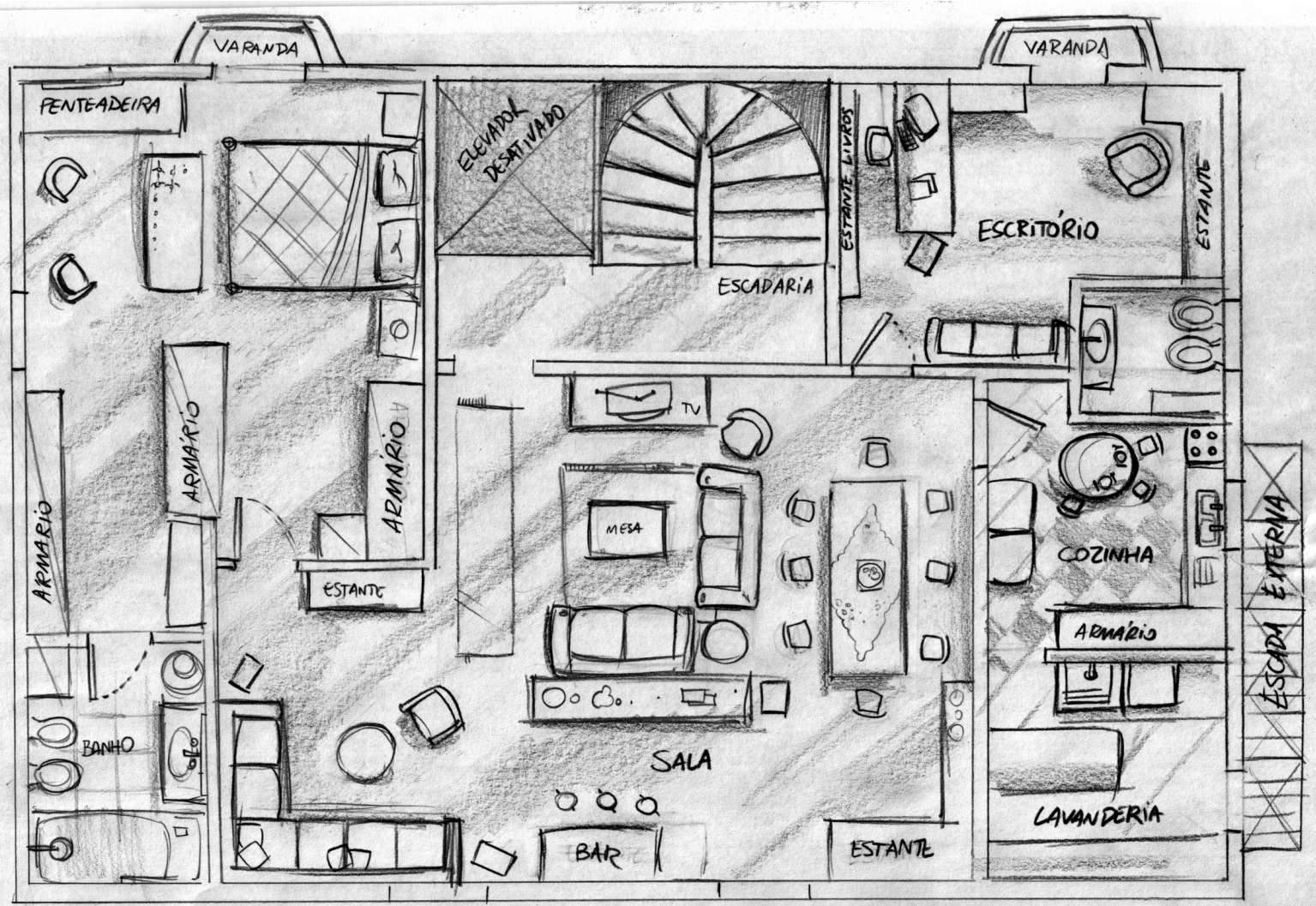

figura 4. Planta $3^{\mathrm{a}}$ andar, apartamento 5 


\subsection{DIREÇÃO DE ARTE}

Desenhos de conceito

LIMBO é um jogo de suspense e mistério. Para que esse clima seja construído, juntamente com a trilha sonora, a parte visual é uma ferramenta fundamental para o desenvolvimento desse universo sombrio. O visual de LIMBO leva o jogador a um pesadelo; tudo é escuro, contrastado e muitas vezes confuso.

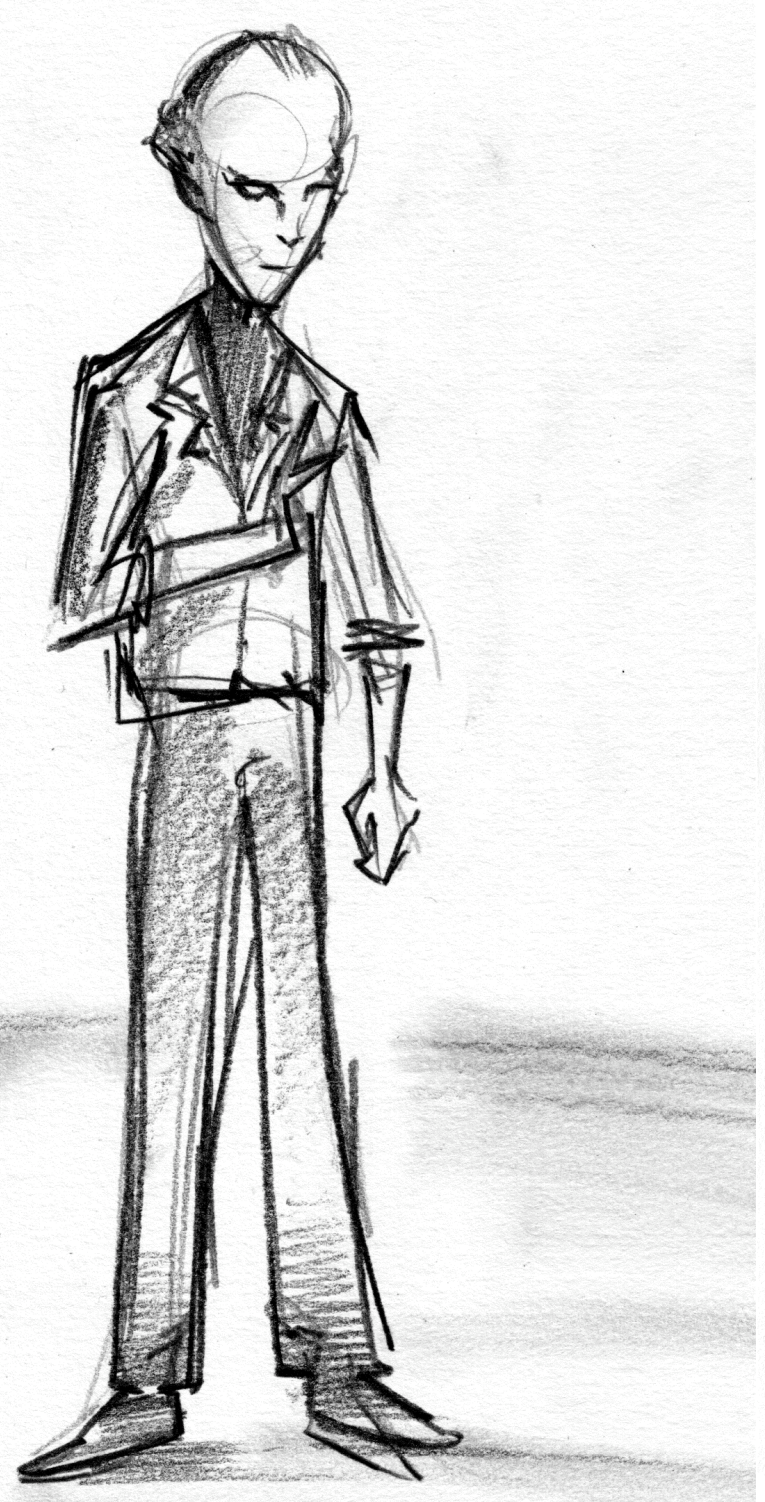

Figura 5. Luiz Grandier, vista de corpo inteiro
Os personagens serão estilizados, distantes das proporções realistas, mas nem por isso aproximam-se do estilo "cartunesco". Os cenários, por sua parte, também serão distorcidos, embora sejam alterações sutis se comparadas à deformidade dos personagens.

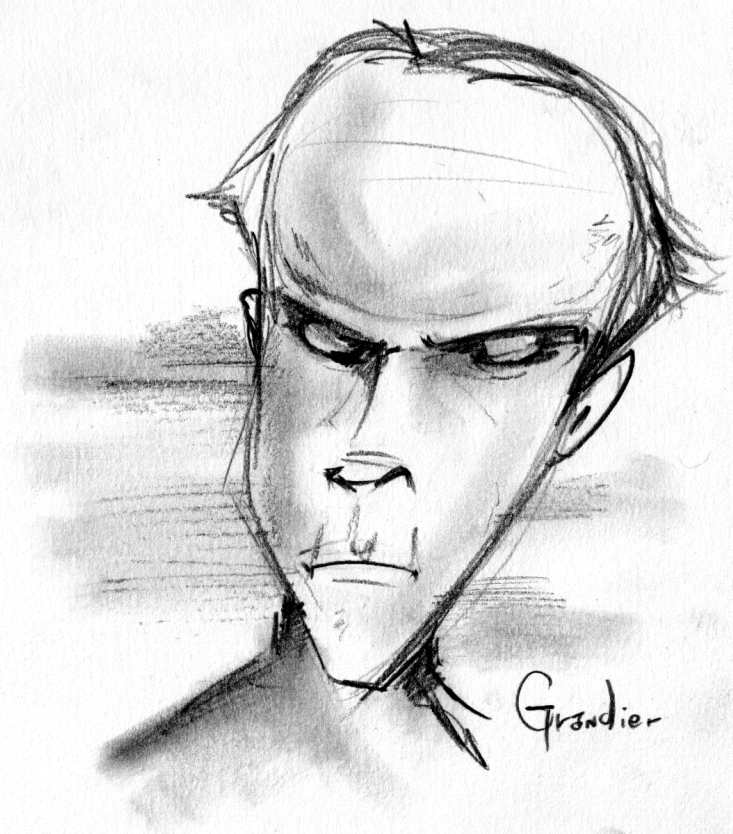

Figura 6. Luiz Grandier, rosto. 


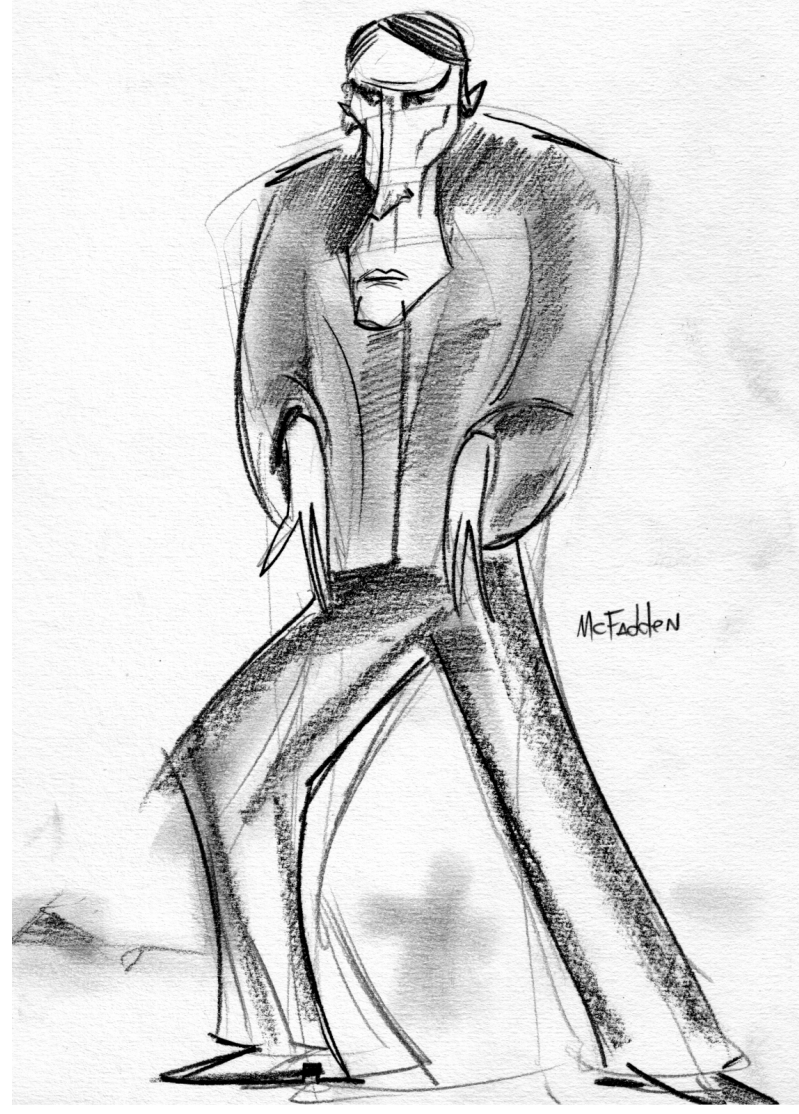

Figura 8. Aníbal McFadden, vista de corpo inteiro

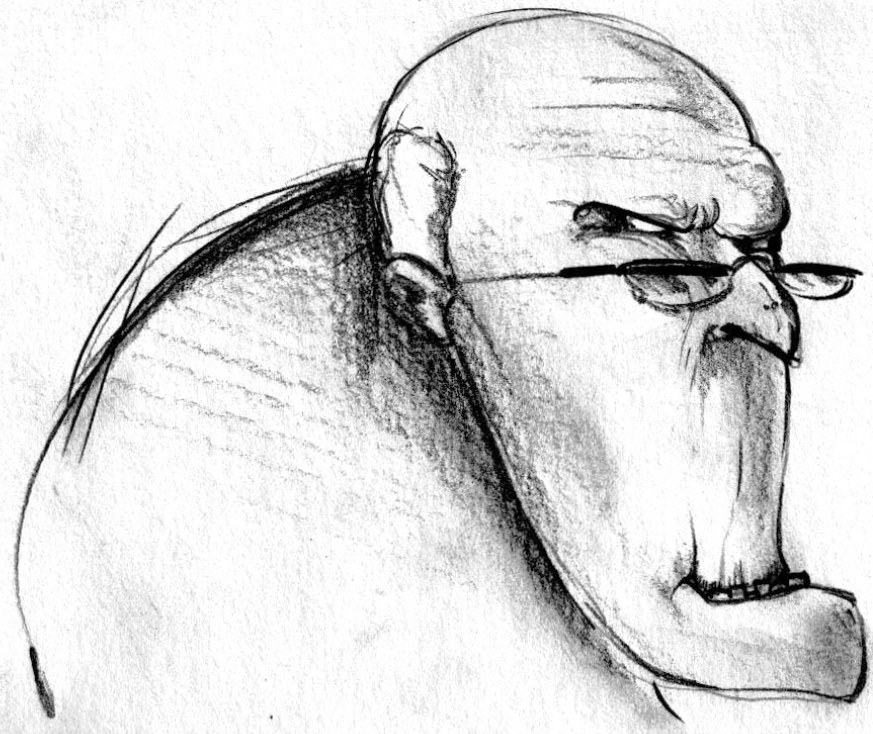

Figura 9, Yan Sudslowsky, rosto

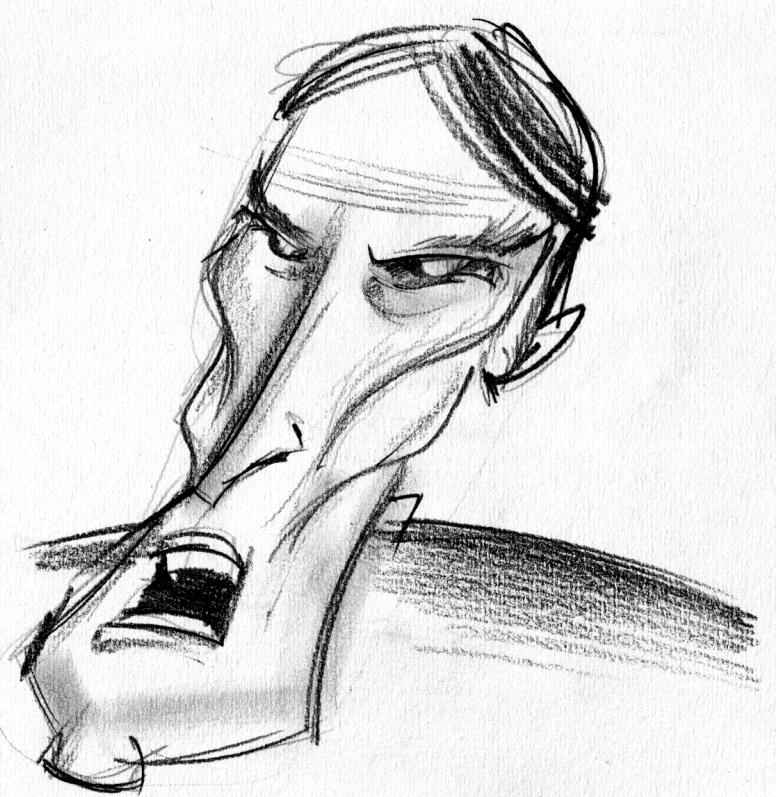

Figura 7. Aníbal McFadden, rosto

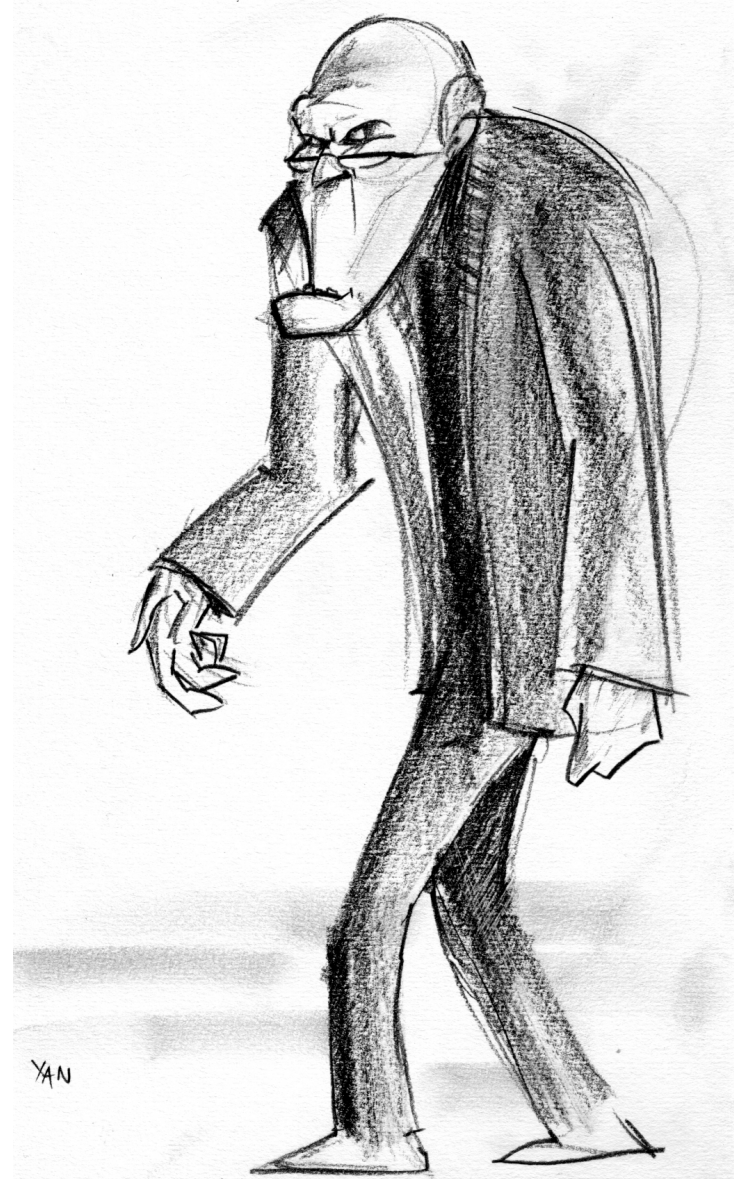

Figura 10. Yan Sudslowsky, vista de corpo inteiro 


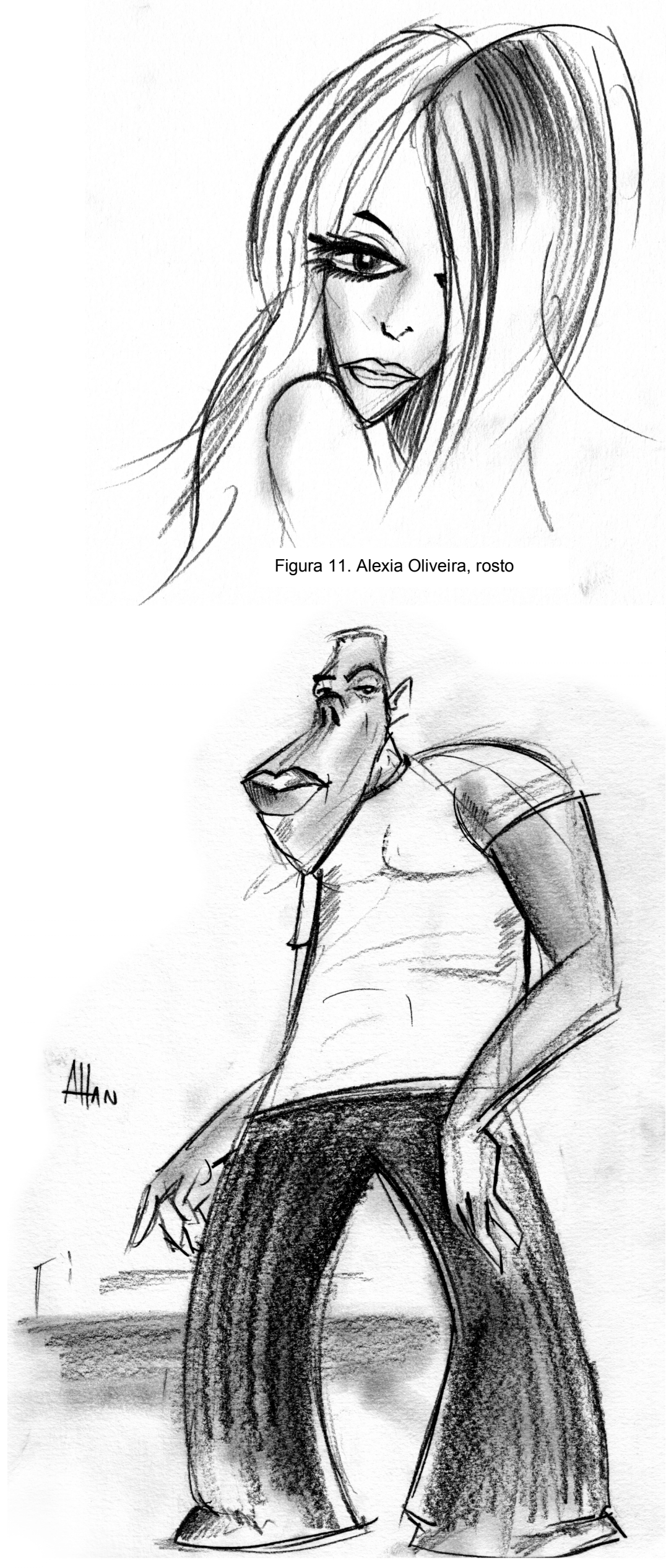

Figura 13. Alan Marinho, vista de corpo inteiro

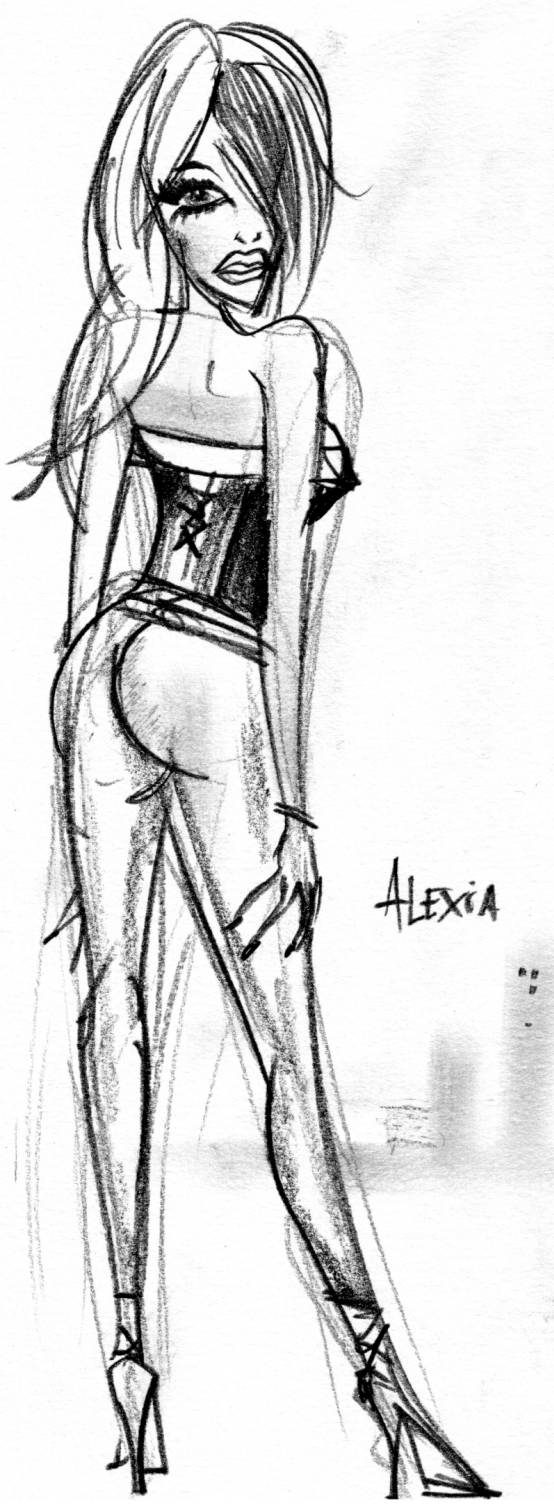

Figura 12. Alexia Oliveira, vista de corpo

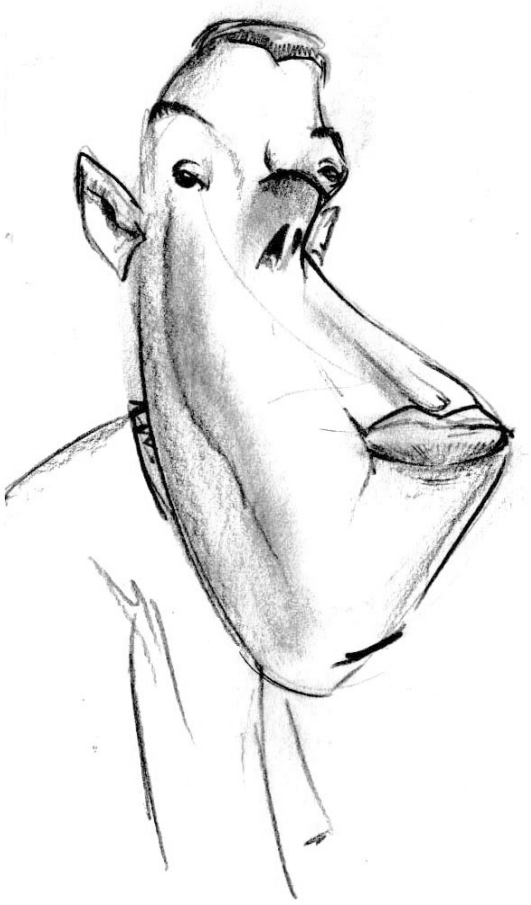

Figura 14. Alan Marinho, rosto 


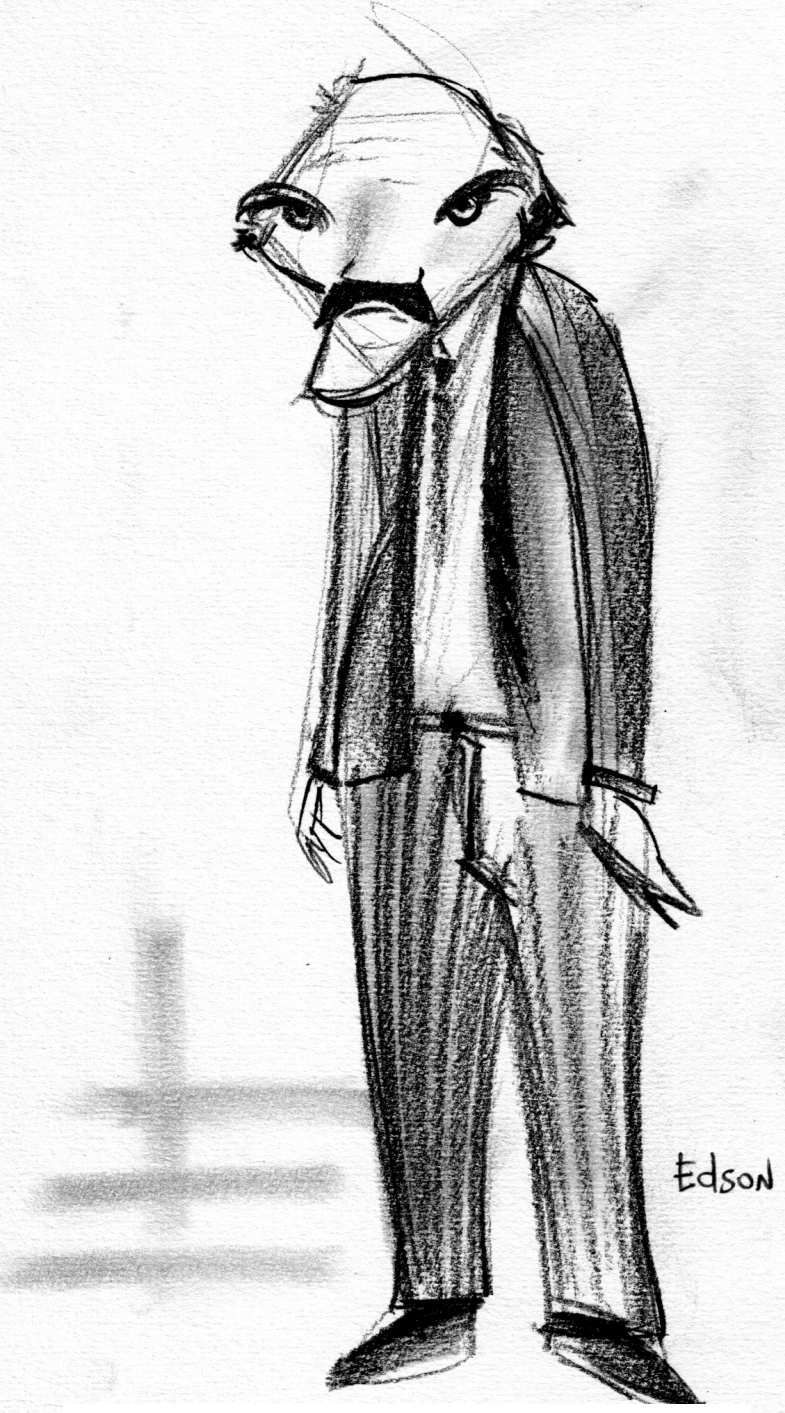

Figura 15. Edson Guariglia, vista de corpo inteiro

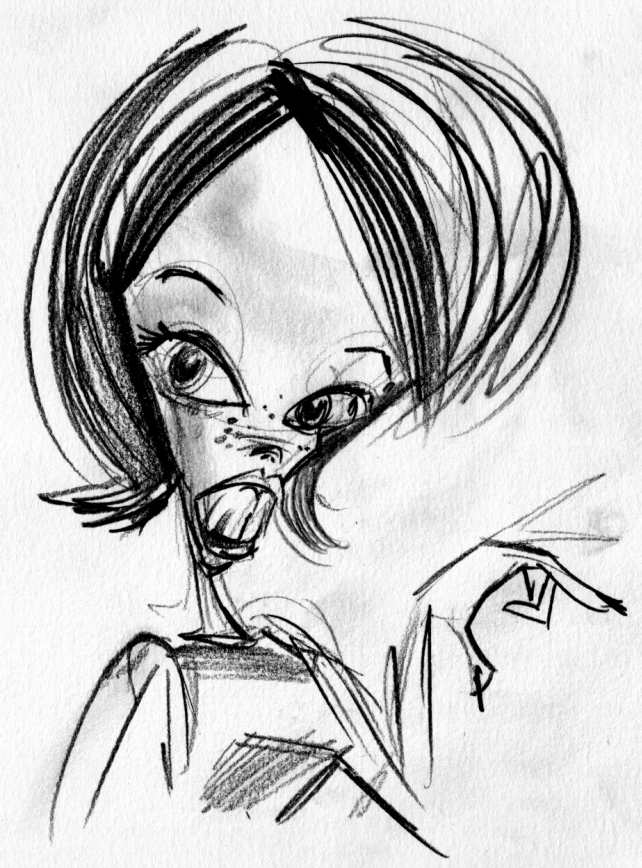

Figura 17. Marilia Guariglia, rosto

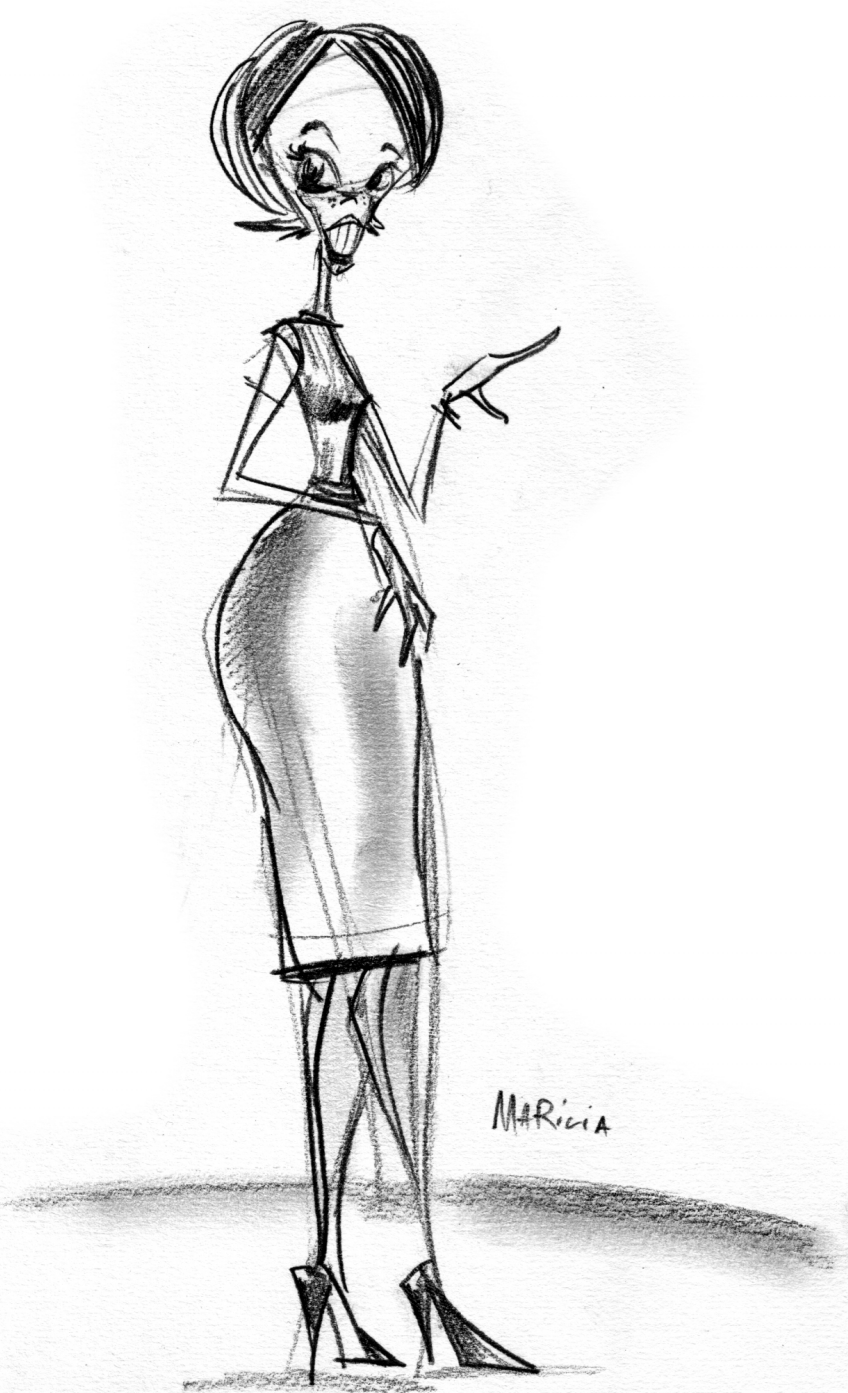

Figura 16. Marília Guariglia, vista de corpo inteiro

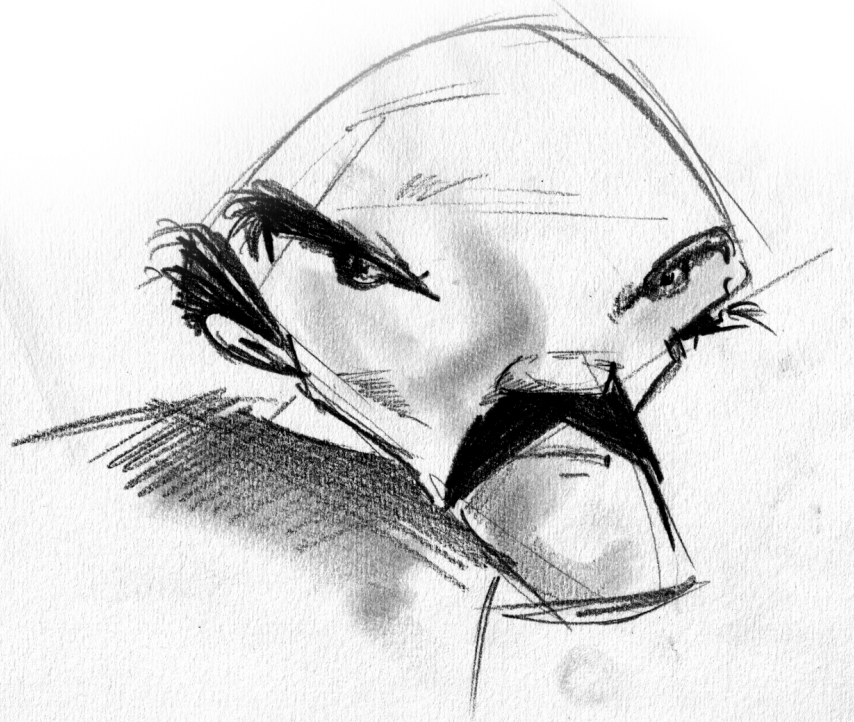

Figura 18. Edson Guariglia, rosto 


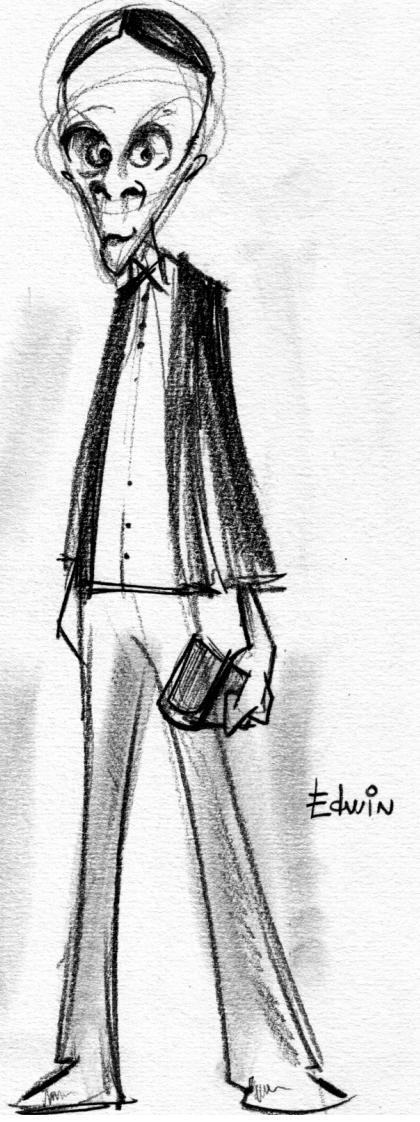

Figura 19. Edwin Souza, vista de corpo inteiro

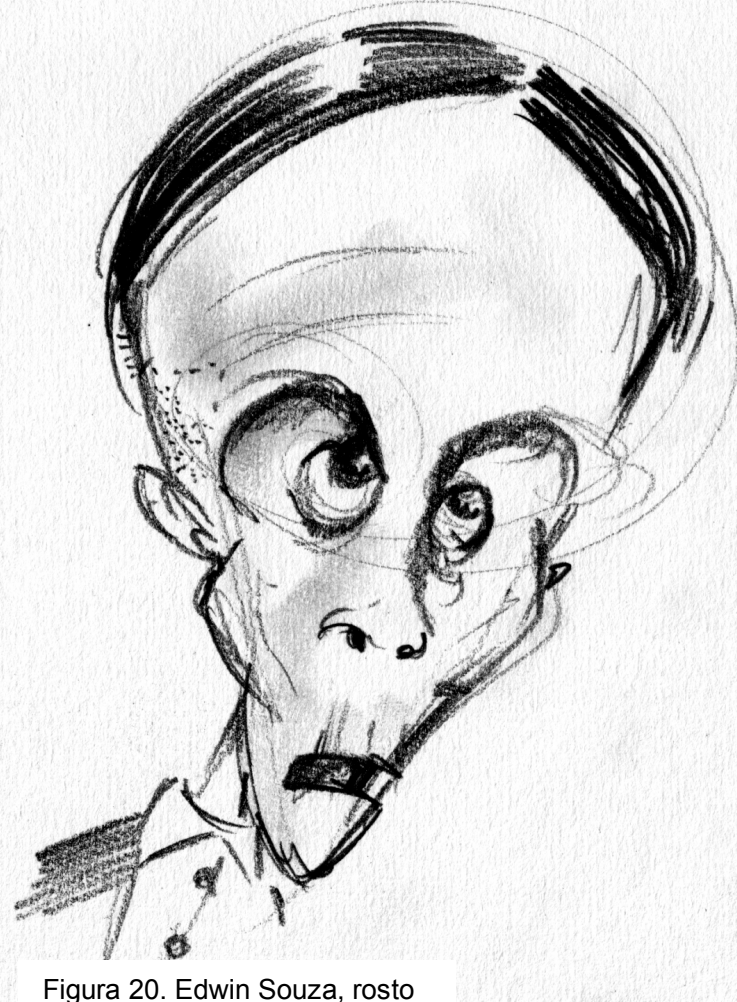

Figura 20. Edwin Souza, rosto

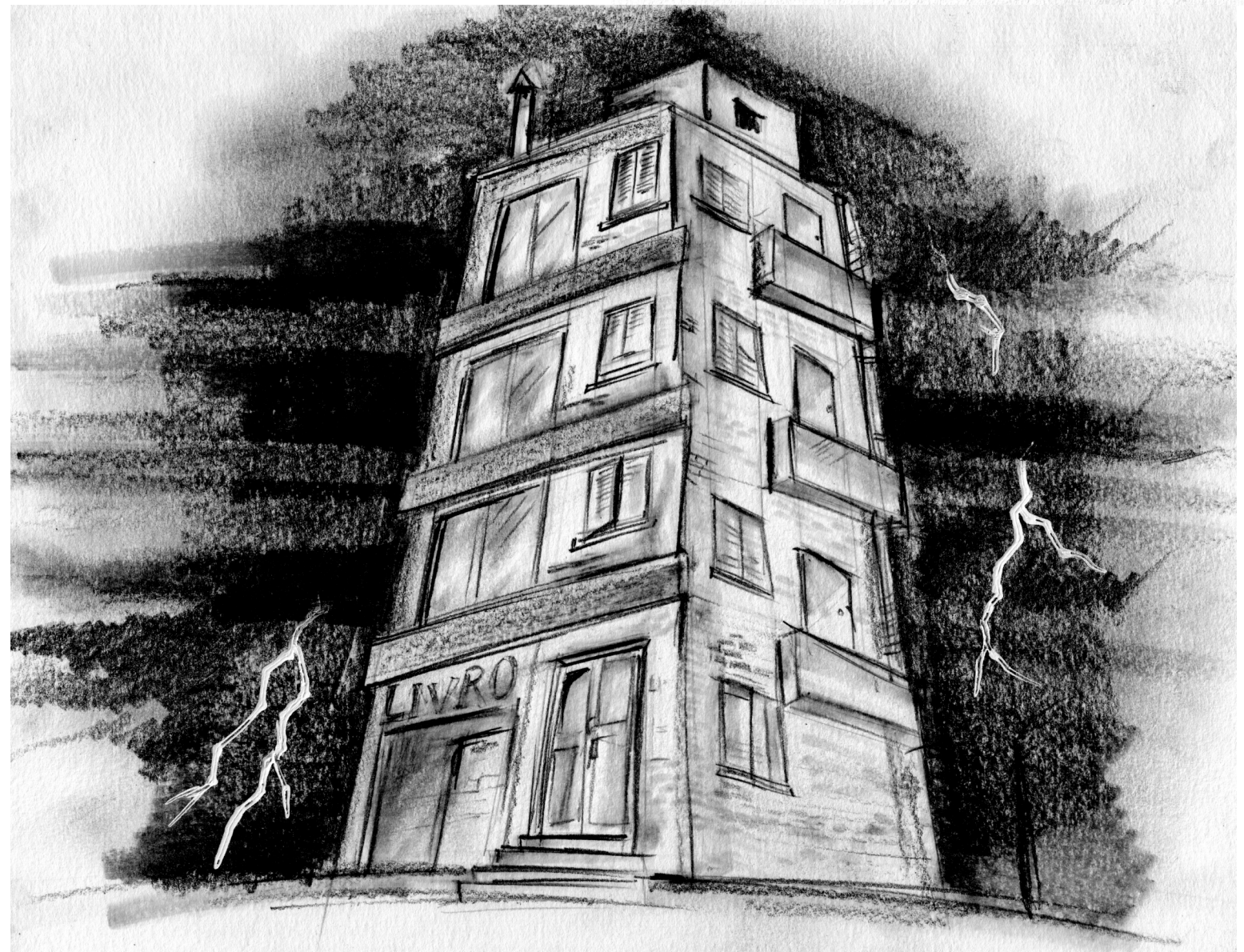

Figura 21. Edificio Plaza Acali 330 durante a tempestade 
Todas as telas do jogo serão em tons de preto e branco - não as escalas de cinza da fotografia comum, mas o preto e branco dos desenhos a grafite, com a granulação da textura formada pelo grafite impresso no papel e a gestualidade própria dos rascunhos. Mesmo na animação 3D os modelos serão envolvidos por uma textura feita com desenhos a lápis.

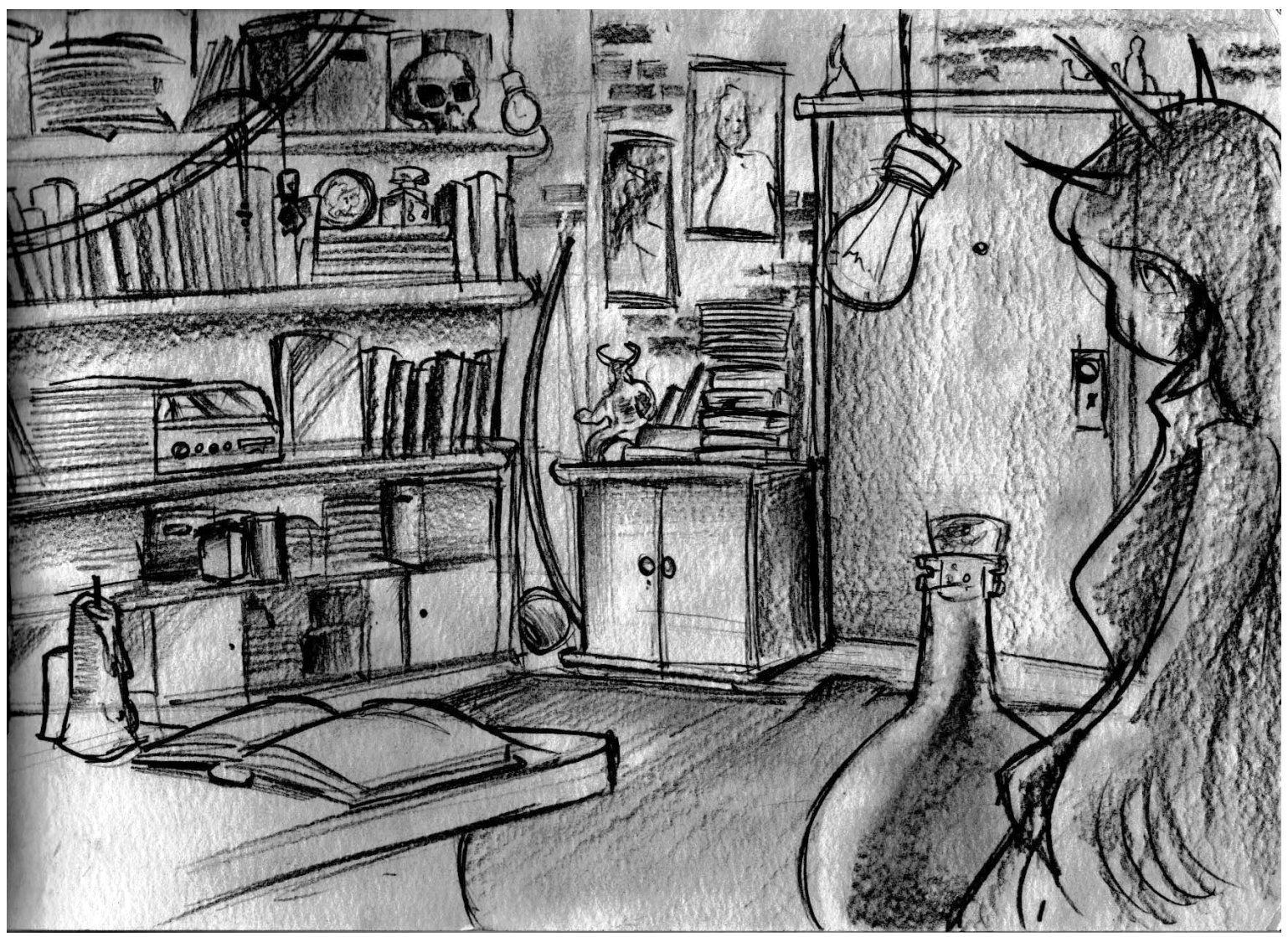

Figura 22. Vista interna do Apartamento de Grandier.

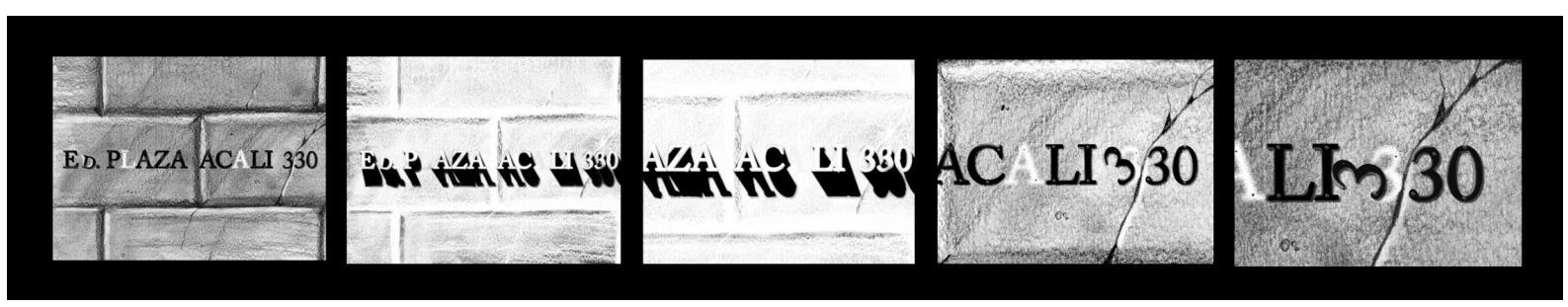

Figura 23. Sequência de imagens mostrando a placa do edifício dando origem ao nome do jogo: "LIMBO" 


\section{CONCLUSÃO}

Foi muito importante começar a criação desse jogo logo após o estudo de "Full Throttle" a partir da ótica de "O Discurso da Narrativa". Durante o desenvolvimento do documento de produção do jogo LIMBO, pude trabalhar com os conceitos narrativos de tempo, modo e voz desde a concepção do jogo. A escolha de contar a história através da ótica de um espírito desencarnado permitiu que eu pudesse usar algo na própria história para fazer referência a essas questões narrativas.

A utilização das memórias de Luiz Grandier me permitiu explorar as questões de anacronia levantadas no primeiro capítulo. Por outro lado, esses retornos ao passado do protagonista são não lineares, dependendo das escolhas do narratário, e é a sua percepção que vai compor a cronologia regular da trama. Todas as analepses criadas pelo retorno às memórias são externas, porém, devido às características da mídia interativa, em LIMBO as analepses externas interferem na narrativa primeira, alterando o desenrolar da história de acordo com as memórias que forem acessadas. Em LIMBO, lembrar deixa de ser um simples retorno e passa a ser uma busca que deve ser realizada pelo protagonista sob o comando do jogador. Sem que Grandier lembre dos encontros com seu mentor, tudo o que ele aprendeu em vida não lhe servirá e só a lembrança das aulas fará o conhecimento ganhar valor. No trecho formado pelas terceira e quarta "fases de controle" de LIMBO o retorno de Grandier ao passado através de seu espírito é uma analepse completiva que permite ao protagonista compreender os eventos passados que levaram aos do início da narrativa primeira. Mas não se trata apenas de

\footnotetext{
${ }^{12}$ É importante fazer uma ressalva ao classificar a quarta "fase de controle" como analepse, já que esse trecho da história traz algo novo: permitir a interferência do personagem, alterando os eventos passados. Porém, se levarmos em conta a possibilidade de o narratário optar por não interferir e apenas assistir ao acontecimento, a quarta fase de controle passa a ser o ponto de encaixe da analepse completiva iniciada na fase anterior.
} 
um recurso narrativo autoral alheio à diegese; na lógica da história de LIMBO o retorno acontece dentro dos princípios estabelecidos por aquele universo diegético.

Confesso que, de certo modo, as questões relacionadas à duração acabaram não sendo aprofundadas em LIMBO. Acabei não fugindo do tratamento praticamente isocrônico em que os "games" acabam por se basear. Porém, o fato de deixar algumas cenas das "fases de controle" acontecerem simultaneamente faz com que a isocronia se transforme num elemento de desafio, já que o jogador deve abrir mão do conhecimento de uma cena específica que acontecerá ao mesmo tempo e com a mesma duração das demais. A isocronia também vai orientar o jogador sempre que ele retornar aos momentos que antecederam a morte do protagonista. A duração dos eventos sempre será a mesma e isso será marcado pelos sons que compõem o assassinato, exibidos na introdução do jogo a partir da focalização externa, que mostra apenas o prédio. Isso nos leva a uma aliança eficaz da duração e do modo.

Genette afirma que pelo modo é que o narrador escolhe tanto a graduação da distância daquilo que se conta quanto a credibilidade da informação passada. Pelas próprias características conceituais de LIMBO, em que a busca por informações - sejam elas nas suas memórias, em eventos presentes e passados - é o que levará o jogador ao objetivo proposto, o controle da informação narrativa é um recurso que vai ajudar a construir os desafios. O narrador em LIMBO é discreto, mas bastante presente, regula a qualidade e quantidade de informação oferecida e está disfarçado entre as regras do jogo.

Acredito que uma das descobertas mais valiosas que fiz ao investigar os jogos usando os elementos narrativos está ligada ao modo tratando-se da focalização narrativa. Genette alerta para uma confusão comum entre modo e voz, uma confusão entre a perspectiva narrativa com 
quem conta a história. Como abordei no primeiro capítulo, nos jogos eletrônicos essa confusão é quase uma constante, presente até em tentativas de definições de gêneros (jogos em "primeira pessoa"). Mas se entendermos que nos "games" a diferença entre quem conta e quem vê traz novas questões, isso pode ser usado como recurso eficiente. Em LIMBO, o jogo é centrado no protagonista e é através de sua percepção que o jogador descobre a história. A história não é contada por Grandier, é vista por ele; entretanto, são as opções do narratário que levarão a história aos desfechos possíveis. Acredito que pude experimentar algo novo ao trabalhar com o modo narrativo dessa maneira, mas as possibilidades são inesgotáveis.

As questões da voz foram as que mais bem pude discutir ao criar LIMBO. Foi justamente para utilizar esses conceitos que optei por trabalhar num universo fantástico, com um personagem póstumo. Assim pude abordar diferentes níveis narrativos através da diegese. Todo os jogos permitem que o narratário - jogador - interfira na narrativa; assim sendo, a metalepse narrativa já é algo pertinente aos "games". O que pude fazer ao escrever LIMBO foi dar um trânsito maior aos níveis narrativos experimentados pelo protagonista. A história de Luiz Grandier começa numa narrativa primeira no início do jogo, durante sua agonizante morte. Em seguida o personagem passa a recordar memórias, numa narrativa de segundo grau, com eventos extra-diegéticos explicativos que não interferem na narrativa de primeiro grau. Depois de desencarnar, o espírito de Grandier deixa o mundo dos vivos, passando a perceber aquele mundo como um intruso, uma testemunha alheia, que pode apenas observar sem nenhuma possibilidade de interferência. Relacionei propositalmente essa alienação do personagem ao universo observado, criando uma metalinguagem para discutir a presença extra-diegética do protagonista. À medida em que Grandier adquire poderes pós-vida, ganha a capacidade de interferir no mundo dos vivos, ou melhor, na narrativa primeira, fazendo sua participação narrativa transitar de uma presença testemunhal extra-diegética até transformar- 
se num personagem intra-diegético com capacidade de interferir no desenrolar dos eventos da diegése.

Do mesmo modo que Genette sugeria que o estudo de "À La Recherche du Temps Perdu" teria sido um pretexto para o estudo da própria narrativa, LIMBO também me serviu de pretexto para investigar a aplicação dos conceitos narrativos aos videogames. Não questiono que ao fazer isso talvez tenha me distanciado do termo "jogo", mas simplesmente recriar um jogo nunca foi o meu objetivo; minha pesquisa procurou algumas possibilidades da interação na narrativa, e as deixo aqui para que futuros autores e "game-designers" possam utilizá-las e levá-las a fronteiras que LIMBO não atingiu. LIMBO mostra o uso de algumas dessas possibilidades narrativas, mas termino esta pesquisa convencido de que não há limites para o uso da interação na narrativa, desde que o autor conheça as questões pertinentes a essas duas áreas, ou, para citar LIMBO, as habilidades só poderão ser utilizadas quando forem conscientes. 


\section{LISTA DE OBRAS UTILIZADAS}

Bibliografia

SALEN, Katie e ZIMMERMAN, Eric. Rules of Play - Game Design Fundamentals,

- 1 ed. Cambridge, Massachusetts, London, England The MIT Press, 2004

GENETTE, Gérard. O Discurso da Narrativa, - Tradução: MARTINS, Fernando

Cabral. 1 ed. Lisboa, Portugal: Vega/Universidade Lda, 1985

TODOROV, Tzevetan. Lês Categories du Récit Littéraire, Communications 8. Litterature et Signification, Larousse, 1967

METZ. Christian. Linguagem e Cinema, Tradução: PEREIRA, Marilda. 1 ed. São Paulo, Brasil: Perpectiva Editora.

Jogos

Super Mario World. Dirigido por Takashi Tezuka. Japão. Publicado por:

NINTENDO. Jogo de ação para Super Nintendo. 1990

Day of the Tentacle. Escrito por Tim Schafer e Dave Grossman. EUA. Publicado por: LUCASARTS. Jogo de aventura para $P C$ 's 1993

Full Throttle. Escrito e dirigido por Tim Schaffer. EUA publicado por:

LUCASARTS. jogo de aventura para PC's. 1994

Grin Fandango. Escrito e dirigido por Tim Schafer. EUA. Publicado por:

LUCASARTS. Jogo de aventura para $P C$ 's. 1998

Grand Theft Auto: Vice City. Escrito por Dan Houser e James Worrall, dirigido por Leslie Benzies. EUA. Publicado por ROCKSTAR NORTH. Jogo de ação para Playstation 2 e PC's. 2002

Resident Evil OutBreak File\#2. Escrito por Kazunori Kadoi, dirigido por Yasunori Ichinose. Japão. Publicado por: CAPCON. Jogo de ação e aventura para Playstation 2. 2004

Onimusha 3. Escrito por Hiroaki Kanazawa e Minoru Nakai, dirigido por Minoru Nakai. Japão. Publicado por: CAPCON. Jogo de ação para Playstation 2. 2004

God of War. Escrito por Keith Fay, David Jaffe, dirigido por Douglas Carrigan. EUA. publicado por: SCEA. jogo de ação para Playstation 2. 2005 


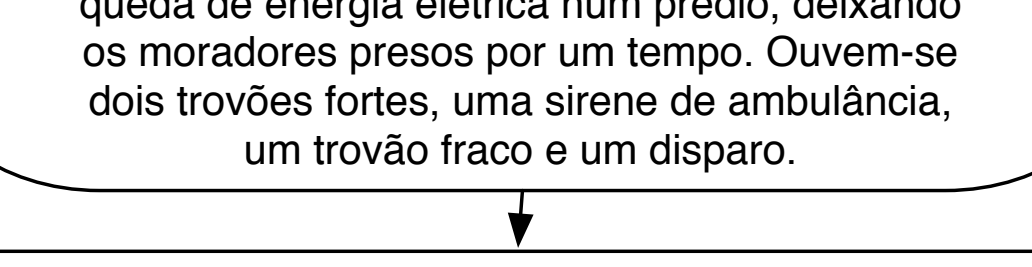

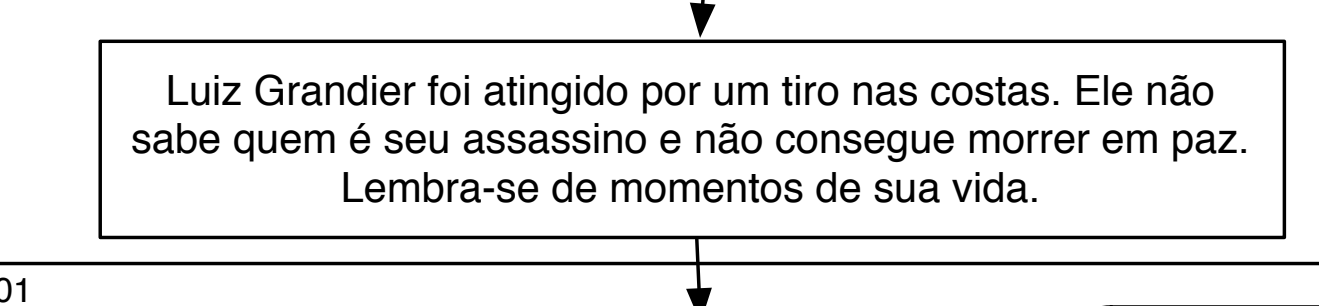

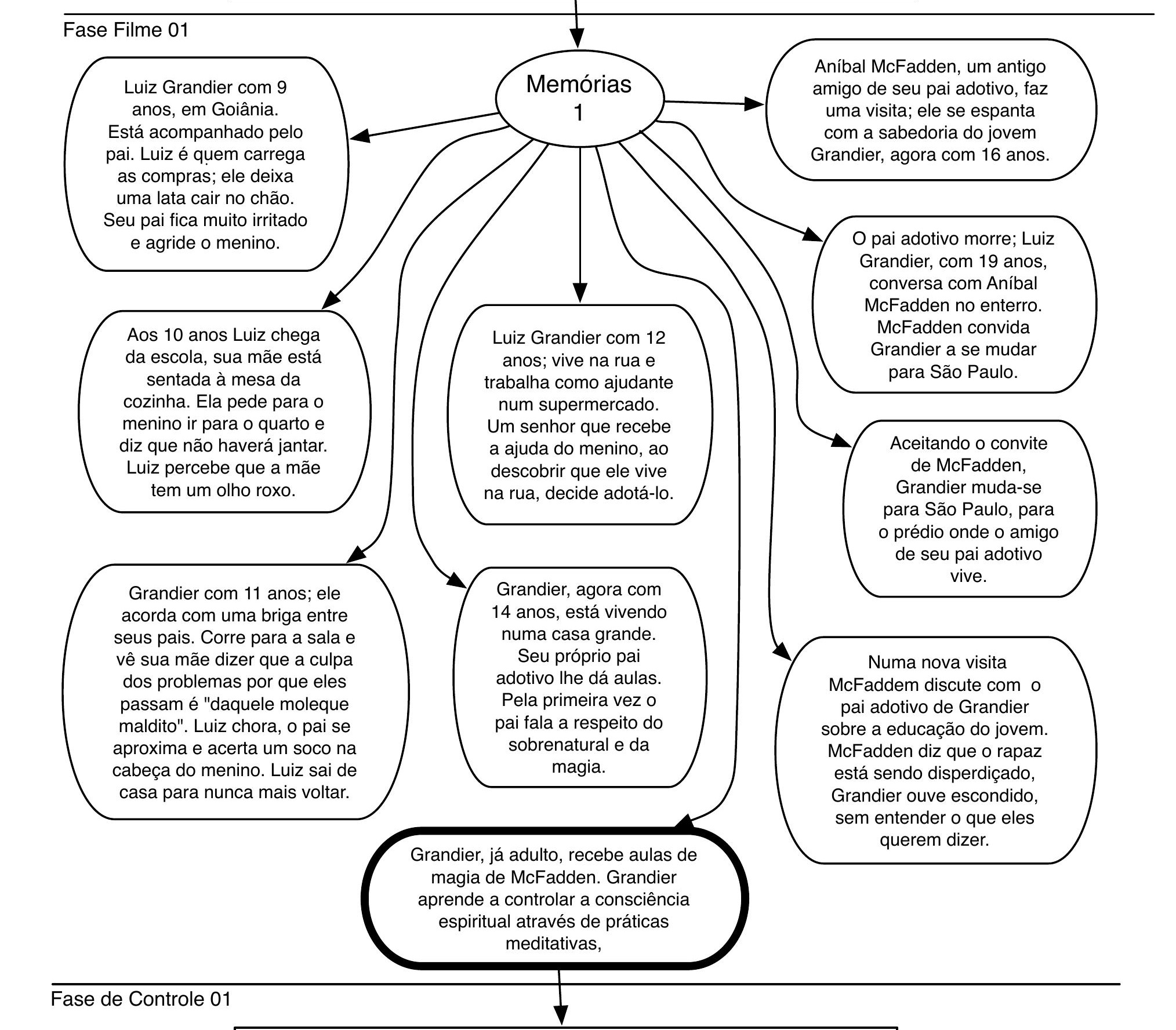

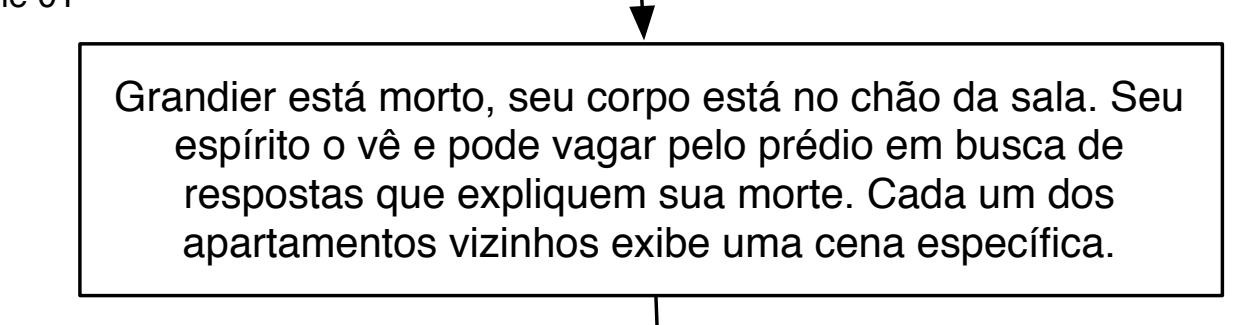

$\equiv=0$

$=3 \quad=3$

$\begin{aligned}= & = \\ = & =\end{aligned}$

$\begin{aligned}= & = \\ = & = \\ = & = \\ = & =\end{aligned}$

T

$=0$

$\equiv$

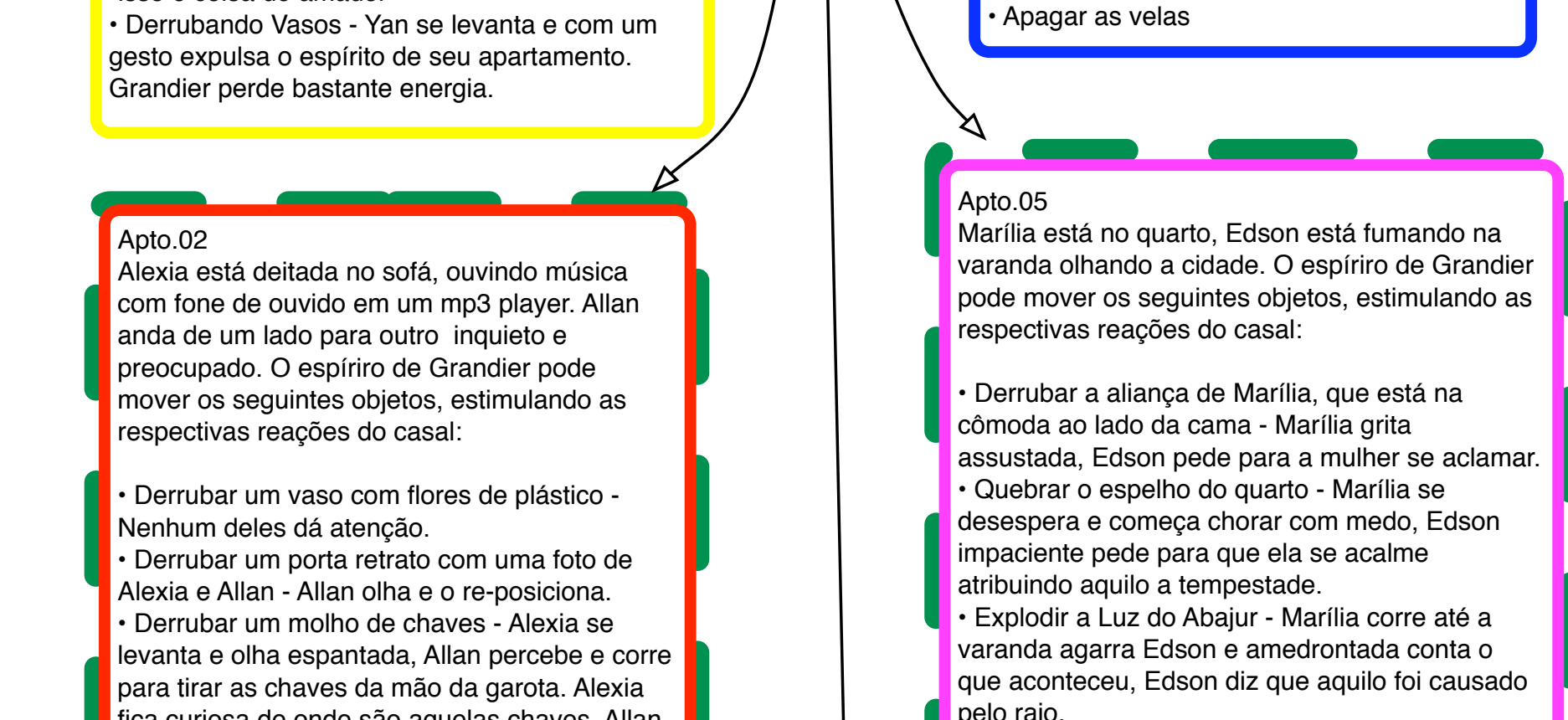

$=$

$=0=$

$=$

$=0$

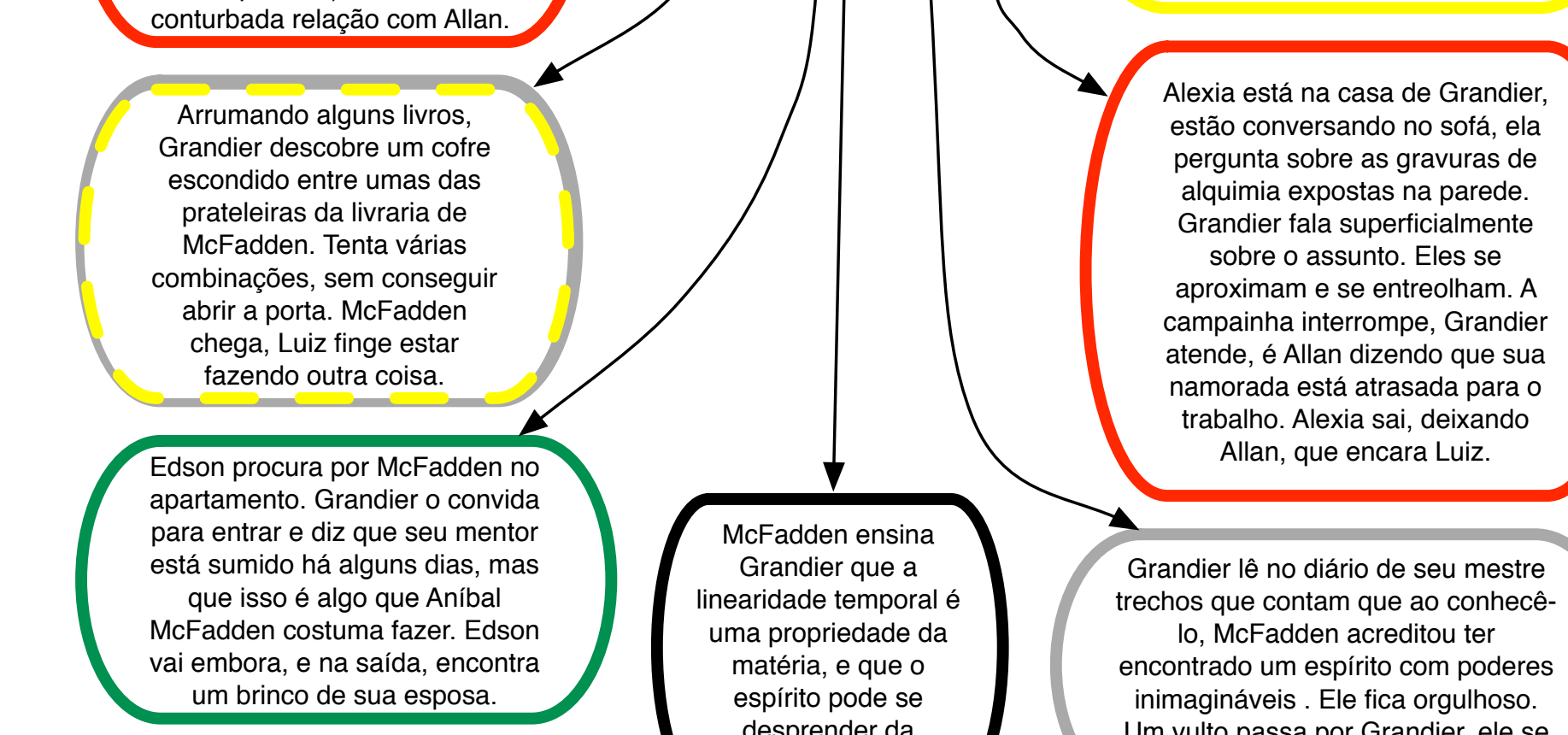

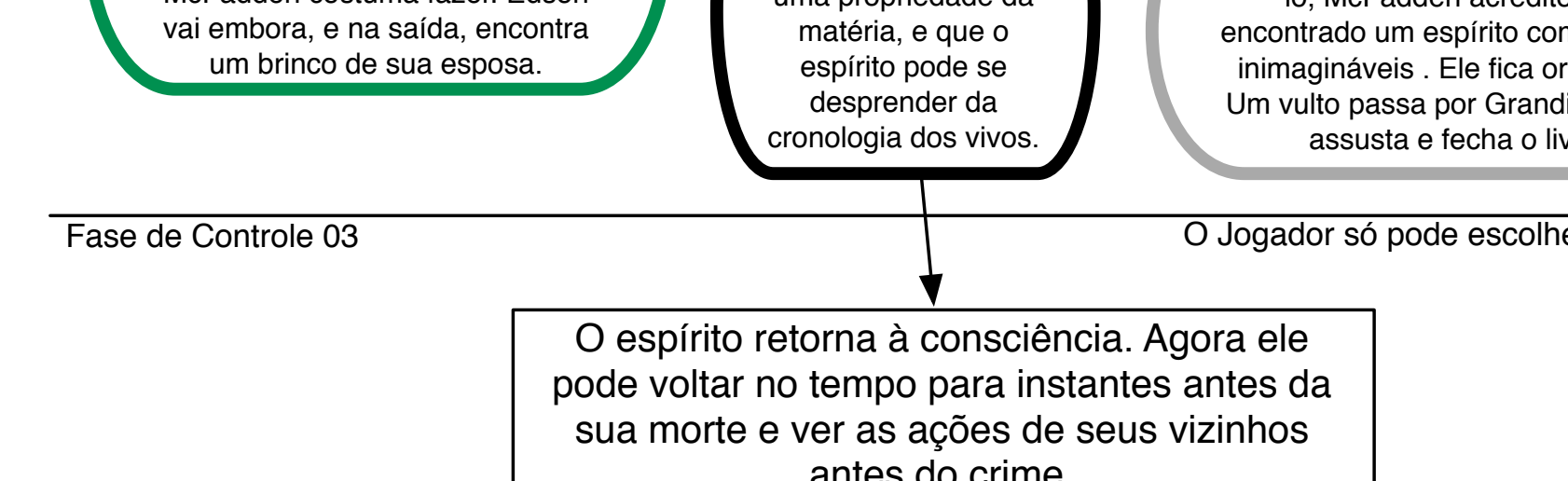

$= \pm=$

$=0$

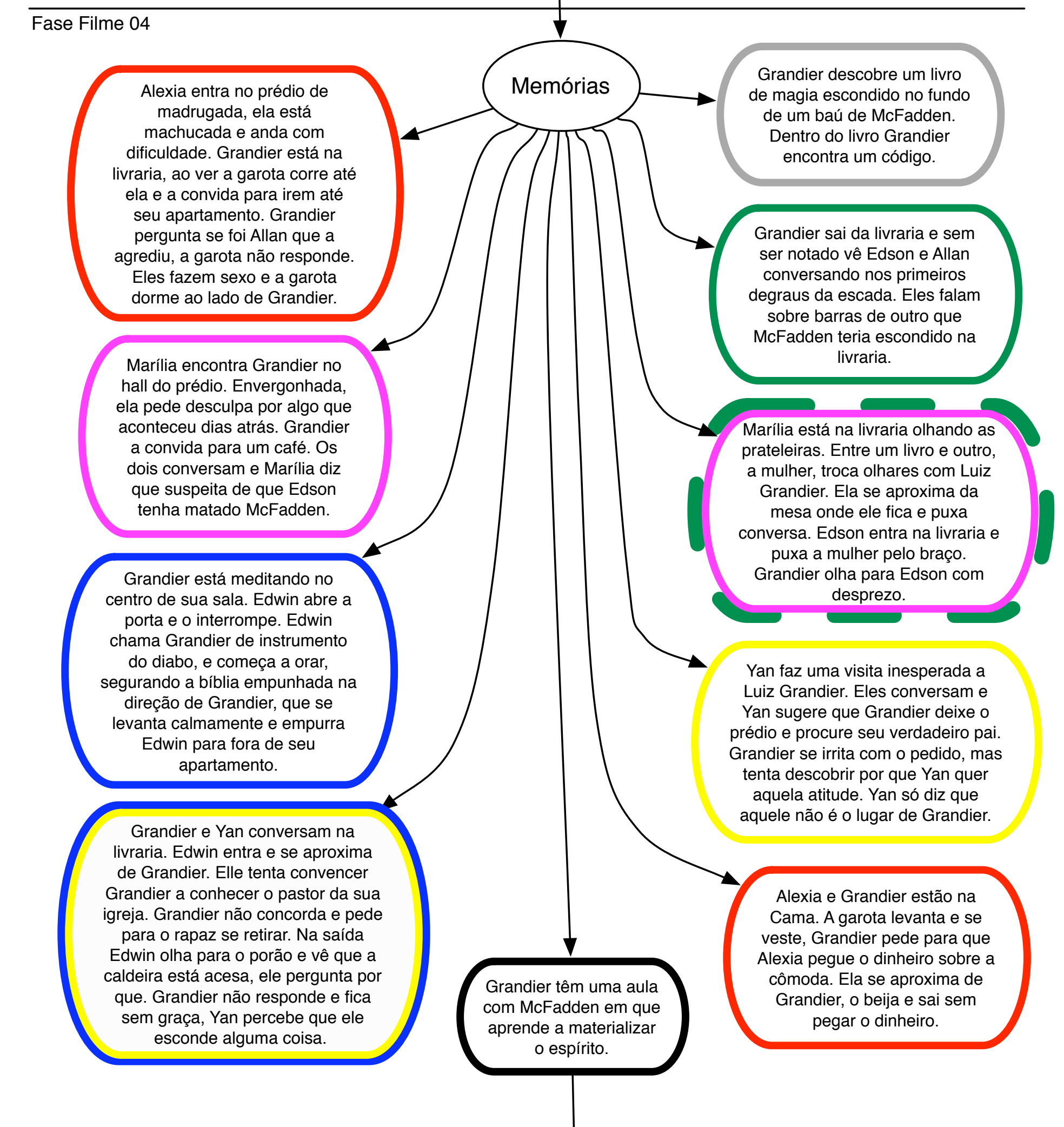

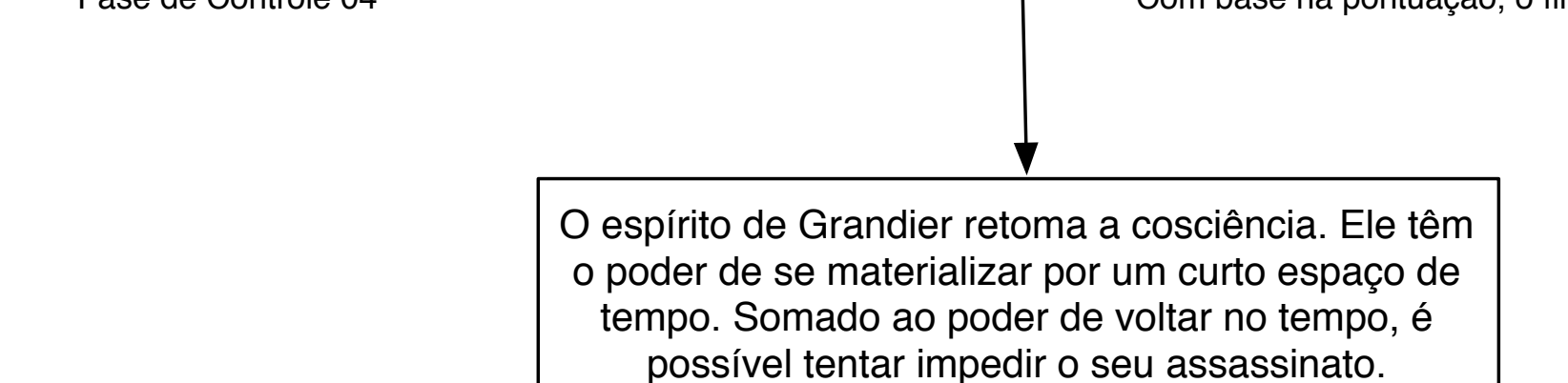

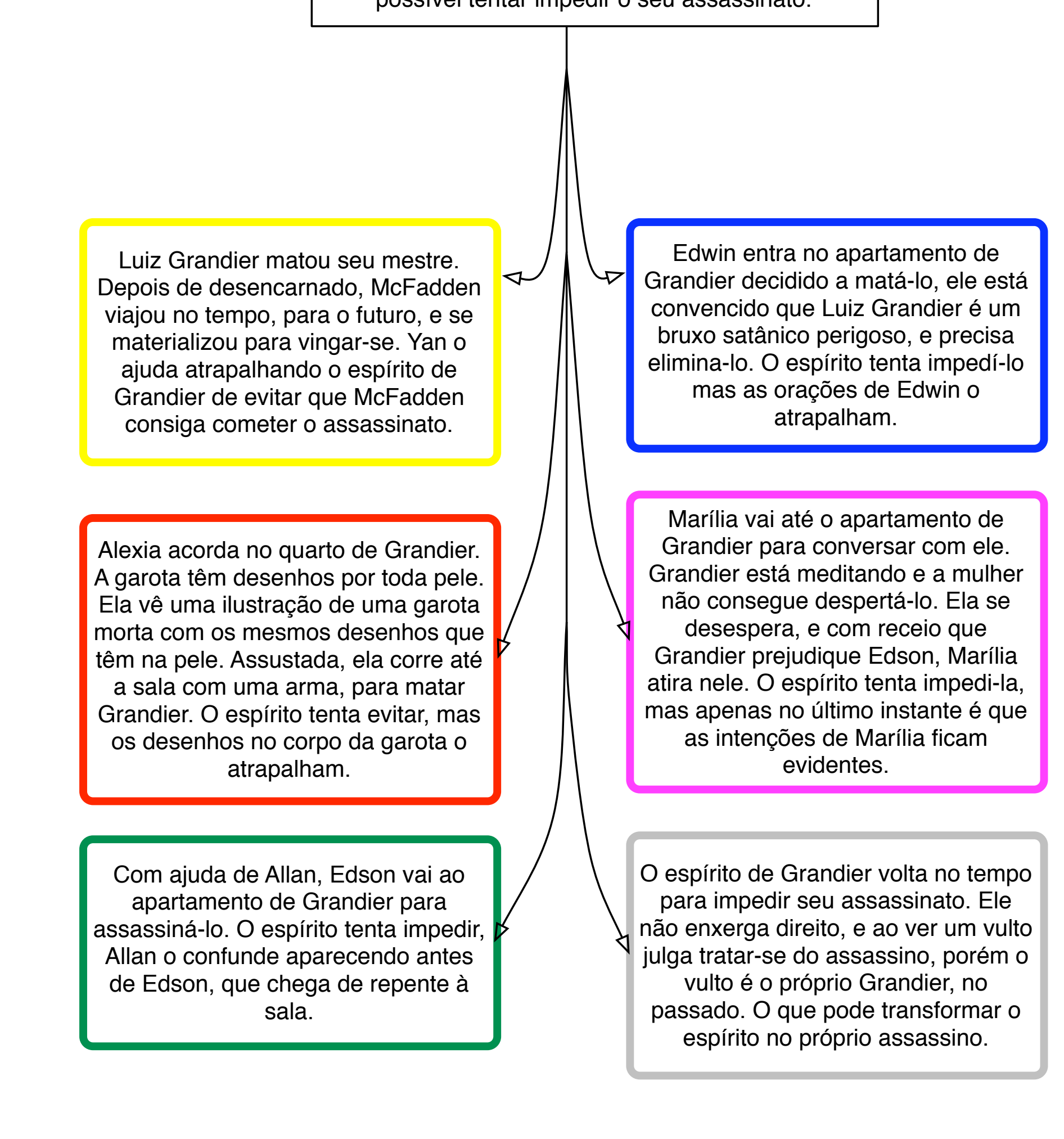

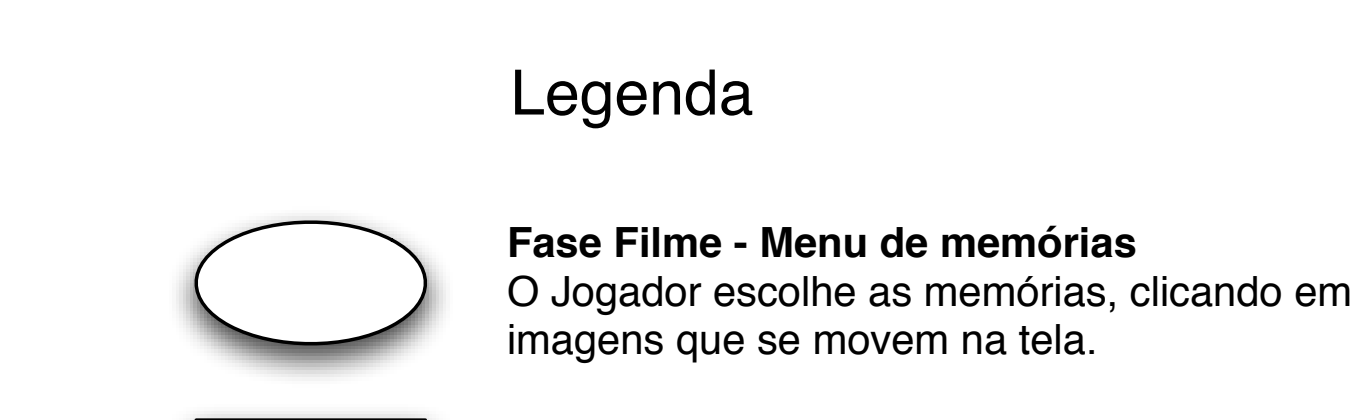

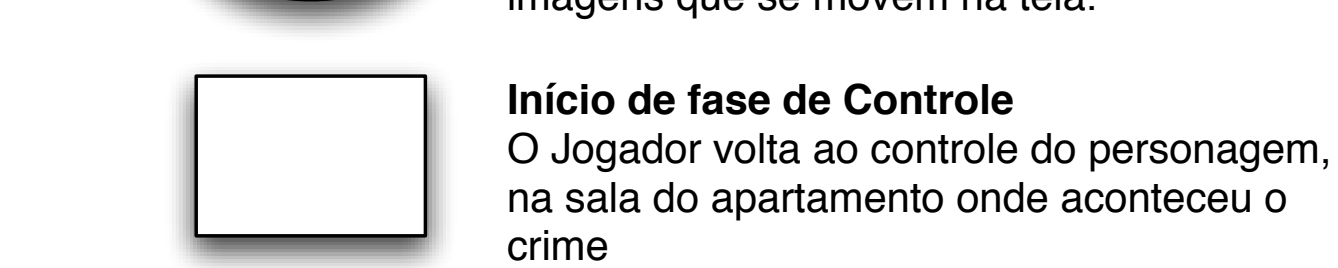

$\square=$

$\square$ and

D.

$:=$

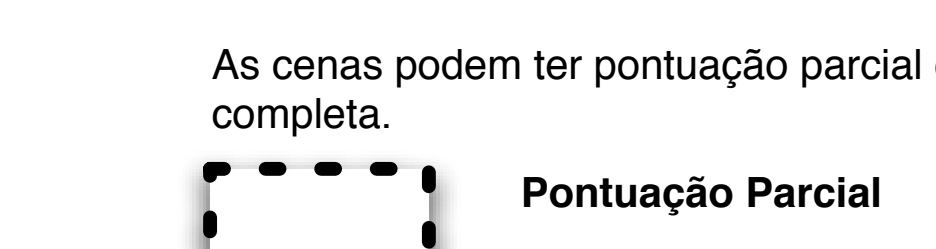

$\square$ 